WILLIAM C. BRAINARD

Yale University

JOHN B. SHOVEN

Stanford University

LAURENCE WEISS

Yale University

\title{
The Financial Valuation of the Return to Capital
}

THE BEHAVIOR of the U.S. stock market over the past decade has puzzled both academic and lay observers. Recent experience casts doubt on the traditional belief that common stocks are an ideal hedge against inflation. Comparisons of the cyclical peak years of 1959, 1968, and 1979 are revealing. The total nominal return from investing in the market portfolio of common stocks has a geometric average of just 4.7 percent a year for the 1968-79 period, far less than the rise in consumer prices of 7.0 percent for the same period. By contrast, stock returns from 1959 to 1968 averaged 9.3 percent while prices rose only 2.1 percent a year. In real terms, stock prices at the end of 1978 (as represented by the Standard \& Poor's 500 ) were about half of their historic peak level of 1968 . For no other ten-year period, including the Great Depression, have stocks performed

The research for this paper was supported by grants from the National Science Foundation, the National Bureau of Economic Research, and the Alfred P. Sloan Foundation. The authors thank Phillip Cagan, members of the Brookings panel, and the participants in the summer workshop in public finance at the National Bureau of Economic Research. We are extremely grateful to Arthur P. Slepian of Stanford University, who spent long hours at the computer terminal, implementing our and his ideas. David Laster of Yale University also made a large contribution to this paper. 
so poorly. This dismal record is only partially explained by aggregate profit figures. Although the rate of growth of real after-tax corporate profits for domestic manufacturers, with correction for both inventory valuation and capital consumption adjustments, has decelerated somewhat (from 2.8 percent a year for 1959-68 to 1.6 percent for 1968-79), the recent growth rate is not significantly different from the long-run growth rate of real corporate profits (1.9 percent for 1948-79). Clearly the ratio of share prices to after-tax and inflation-adjusted earnings has shown a significant and unexplained decline.

The negative correlation between observed stock prices and inflation in recent years has been widely documented. ${ }^{1}$ One possible explanation of this phenomenon, emphasized by Martin Feldstein and others, is that under U.S. tax laws inflation increases the real tax burden on corporate capital. ${ }^{2}$ The tax effect is primarily due to historical cost depreciation and taxation of nominal capital gains; however, it does not easily explain the decrease in market values relative to after-tax earnings. Furthermore, not all tax effects of inflation are negative. Inflation-induced increases in nominal interest payments are fully deductible even though they are in effect repayment of principal. Measuring the quantitative importance of these tax considerations is difficult because changes in inflation have effects that are spread over the future, and hence could be expected to show up in stock values before being reflected in after-tax earnings. Feldstein does not believe that the increases in the real tax burden are sufficient to account for the current depressed level of the market. He cites also the "transitory" reduction in before-tax profitability, higher tax rates on capital gains, and increased uncertainty associated in part with an increasing ratio of debt to equity. He also admits "the share price level may therefore have overshot its equilibrium level." ${ }_{3}$ Franco Modigliani and Richard

1. See, for instance, Phillip Cagan, "Common Stock Values and Inflation-The Historical Record of Many Countries," National Bureau Report Supplement, 13 (National Bureau of Economic Research, 1974); Zvi Bodie, "Common Stocks as a Hedge Against Inflation," Journal of Finance, vol. 31 (May 1976), pp. 459-70; and John Lintner, "Inflation and Common Stock Prices in a Cyclical Context," in National Bureau of Economic Research 53rd Annual Report, September 1973, pp. 23-26.

2. Martin S. Feldstein, "Inflation and the Stock Market," American Economic Review, vol. 70 (December 1980), pp. 839-47.

3. Feldstein, ibid., p. 846. 
Cohn also question market efficiency in light of recent experience. ${ }^{4}$ They explain the market's decline by "two major, inflation-induced errors in evaluating corporate assets." ${ }^{{ }_{5}}$ Equity holders fail to take into account the real depreciation of nominal corporate liabilities and commit the additional error of discounting equity earnings at the nominal interest rate rather than at the theoretically indicated real rate.

The current depressed level of the stock market is not the only puzzling aspect of the U.S. equities market. Stock prices have always been volatile in comparison with aggregate earnings and dividends that exhibit relative stability. Stephen LeRoy and Richard Porter have investigated whether the observed standard deviation of total annual returns of common stocks of over 22 percent is consistent with the simple model of stock valuation (equal to the present discounted value of expected future earnings). ${ }^{6}$ They conclude that the observed variability is between three and four times as large as that suggested by a model of earnings projections consistent with the observed time series properties of earnings and a constant discount rate. Robert Shiller reaches a similar conclusion. He finds that the informational content of aggregate dividend changes can explain only one-fourth of the changes in aggregate share value. ${ }^{7}$

Equities, of course, are only one of the claims against corporate capital, and some events-for example, unanticipated changes in the expected rate of inflation-redistribute earnings between bond and equity holders. Although the behavior of the stock market is a dominant concern to some investors, from society's perspective the more relevant concern is how the market values the capital stock, the major component of national and private wealth. Further, empirical studies suggest that the market value of capital relative to its replacement costs is an important determinant of physical investment in capital. The market value of capital, defined as the sum of the market values of the equity and bond claims against it, has

4. Franco Modigliani and Richard A. Cohn, "Inflation, Rational Valuation, and the Market," Financial Analysts Journal, vol. 35 (March-April 1979), pp. 24-44.

5. Modigliani and Cohn, ibid., p. 25.

6. Stephen F. LeRoy and Richard D. Porter, "The Present-Value Relation: Tests Based on Implied Variance Bounds," Econometrica (forthcoming).

7. Robert J. Shiller, "Do Stock Prices Move Too Much To Be Justified By Subsequent Changes In Dividends?" Working Paper 456 (National Bureau of Economic Research, February 1980). 
shown the same decline relative to the sum of after-tax earnings and interest as the stock market itself. Similarly, the ratio of the market value of capital to its replacement cost, $q$, has dramatically decreased from its peak in the mid-1960s.

No study has attempted to decompose systematically movements in either share values or the market value of capital into movements of the factors necessary for valuation theories. Broadly speaking, three elements are required: expectations of future dividends or earnings, the pure rateof-time discount appropriate to risk-free streams, and the adjustment necessary for risk in uncertain environments. Clearly, no theory asserts that these factors remain constant through time or that they evolve deterministically. To assess the usefulness of models of rational valuation, these factors must first be quantified. This requires more than simply an examination of aggregate earnings and market values, because if risk and time discounts are allowed to vary without restriction, the model is underidentified.

In this paper we examine cross-sectional evidence on the valuation of firms at different times to estimate the time discounts and risk adjustments necessary to explain observed market values. Cross-sectional variation in the relevant measures of the riskiness of earnings streams with the same time sequence of expected returns enables us to identify separately risk and time discount factors.

In the discussion below we describe the method of calculating the present discounted value of future cash flows for the 187 firms in our sample. This involves calculation of the age structure of each firm's capital, its current replacement value, and its rates of return for each firm for the 1958-77 period. We also compute an aggregate series of gross and net rates of return and compare these estimates with those previously published. We then present the method for calculating the market values of firms; the corresponding $q$ are also shown. To explore the sensitivity of our results to variations in assumptions about expectations formation, we use ten different methods of forecasting future earnings. We report internal rate of return and the ratio of market value to present discounted value for several discount rates. Finally, we discuss the measurement and valuation of risk and report on regressions that attempt to explain the deviations of market value from present discounted value in terms of a variety of variables, including those attempting to measure inflation and accounting illusion. 


\section{Intrinsic Valuation of the Firm}

We begin by assuming that the market value of a firm reflects its "intrinsic value," defined as the present discounted value of expected cash flows, adjusted for risk. These expected cash flows are assumed to reflect the expected before-tax gross rate of return on capital, amount of capital at each future date, payment of taxes, purchases of new capital and sales of debt. By using a before-tax gross rate of return and separately calculating taxes, we are able to capture explicitly the intertemporal and nonneutral interaction of inflation and the tax law. An increase in the rate of inflation, for example, has little effect on the real value of tax depreciation in the first year; the discrepancy between historical and replacement cost depreciation grows over time until it reaches an asymptote. The present discounted value of these effects is captured in the intrinsic value.

The first assumption we make in deriving our estimates of intrinsic value or the present discounted value of the firm is that a firm's capital consists of a portfolio of plant, equipment, and land of different ages. Plant and equipment are taken as "one hoss shays" or "light bulbs" - they are assumed to remain fully productive until they suddenly fail. The date of failure or retirement is estimated from depreciation data. The future productivity of the capital is uncertain, but it is independent of age. No explicit account is taken of technological progress.

We compute two measures of intrinsic value. The first, called cash-out intrinsic value, assumes that the value of a firm reflects only the returns on existing capital. Future investments have zero economic rent-the present discounted value of their expected returns is equal to their costs. Any site rents reflecting patents, monopoly position, and so forth are associated with the existing capital. The second measure, the constantcapital intrinsic value of a firm, is based on the assumption that each unit of capital is replaced at the end of its economic lifetime. The intrinsic value is the present discounted value of the cash flows generated minus the funds necessary to purchase the replacement units. New and old units earn the same real before-tax rate of return, and thus any economic rents associated with the old units continue in the new. A fraction of replacement investment is financed by the sale of debt. We assume that new issuance of debt is proportional to new investment. The fraction of new debt to new investment for a particular firm is chosen each year so that the implied 
interest payments match the actual interest payments. The assumption that firms maintain a constant ratio of new debt to investment implies that the tax saving from increased inflation is less than in Feldstein's calculations, in which savings are taken to be proportional to outstanding nominal debt. In our calculations the real value of debt per unit of capital declines with increased inflation, partly offsetting the higher nominal interest rates associated with any given level of real debt.

These are only two of many possible ways to assess the fundamental value of a firm, and each involves rather strong assumptions. In the cashout case, any new investment is assumed to break even; the present value of the firm is solely a reflection of past investment decisions. In the constant-capital case, new capital earns the same gross rate of return as old capital, and firms invest sufficiently to maintain the capital stock, whether or not it is profitable. Neither case allows the amount of investment to depend on its profitability, and therefore both represent lower bounds on the economic value of the firm. The calculation of intrinsic value itself is obviously sensitive to our assumptions about the processes generating future rates of return. It also depends crucially on the estimated composition, useful life, and age structure of the firm's real assets. In the constantcapital case, intrinsic value is not as sensitive to our estimates of lifetime and capital composition as in the cash-out case, but it is sensitive to our estimates of the replacement cost of capital that wears out.

The assumption that capital is a one hoss shay with returns to a unit of capital independent of its age is artificial. Moreover, it does not explicitly take into account obsolescence, probably the most important factor in determining actual lifetimes. Ignoring obsolescence leads to an underestimate of the returns on new capital and an overestimate of the returns on old. With a positive discount rate this tends to give a downward bias to the estimated discounted value and underevaluation of firms with new capital as compared to those with old.

In principle it is possible to test the importance of some of these misspecifications. Direct information is available on the age structure and replacement cost of the capital stock. The importance of long-lived intangibles is more difficult to test because they cannot be measured directly. Information on industrial structure-concentration ratios and so forthcould be taken as a proxy for such rents and used to explain the gross rate of return. 
CALCULATING AgE STRUCTURE AND REPLACEMENT VALUE OF CORPORATE CAPITAL STOCK

To determine the age composition of the existing capital stock for each firm for each year from the data available we make two additional assumptions. First, there are only two types of capital goods: equipment and plant plus land (assumed to be used in fixed proportions). Both types are taken to be one hoss shays. Second, the proportion of equipment in the gross investment by a specific firm, $f_{e}^{j}$, is constant throughout the sample period.

The useful lifetime of each firm's equipment and plant is determined from its book depreciation and capital stock reported in 1975 Security and Exchange Commission 10-K reports. These lifetimes were taken as constant for the entire sample period, 1958-77. Lifetimes are calculated by assuming that the firms used straight-line depreciation for book purposes. The proportion of new investment that is equipment, $f_{e}^{j}$, was inferred from the firm's actual investment history and the depreciation and gross capital stock it reported in 1975 . We know that straight-line depreciation (dropping the $j$ superscript) implies

where

$$
\operatorname{Dep}_{75}=f_{e} \sum_{i=1}^{L_{e}} \frac{I_{75-i}}{L_{e}}+\left(1-f_{e}\right) \sum_{i=1}^{L_{p}} \frac{I_{75-i}}{L_{p}},
$$

$$
\begin{aligned}
D e p_{75} & =1975 \text { depreciation } \\
I_{75-i} & =\text { the total investment in current dollars in year } 1975-i \\
L_{e}, L_{p} & =\text { equipment life and plant life, respectively. }
\end{aligned}
$$

We also have

$$
G K_{75}=f_{e} \sum_{i=1}^{L_{e}} I_{75-i}+\left(1-f_{e}\right) \sum_{i=1}^{L_{p}} I_{75-i},
$$

where $G K_{75}$ is the book value of gross capital stock in 1975. Using data from the Compustat file, this can be solved for $f_{e}$ :

$$
f_{e}=\frac{G K_{75}-L_{p} \text { Dep }_{75}}{\left(1-\frac{L_{p}}{L_{e}}\right) \sum_{i=1}^{L_{e}} I_{75-i}} .
$$

As a simple test of this procedure we compare the implied depreciation year by year with that actually reported. The ratio of the implied depreciation to the reported depreciation average for all firms ranges 
from 0.93 in 1967 to 1.02 in 1976 . Over the entire sample the ratio is 0.98 . There is, however, substantial variation among firms around these averages; the effect of these errors on our results is estimated below. The average depreciation life for equipment for our firms is 14.5 years, while for plant it is 35.0 years.

Because the Compustat data covers only the 1958-77 period, we are forced to create a "synthetic" investment history for each firm before 1958. The time pattern of investment in the years before 1958 is derived by assuming that the ratio of a firm's investment to aggregate investment changed at a constant rate $\theta$. A firm's $\theta$ is obtained by solving the following equation to equate the implicit gross capital stock to the actual capital stock in 1958 :

$$
\begin{aligned}
G K_{58}= & I_{58}+\left(1-f_{e}\right) \sum_{i=1}^{L_{p-1}} A_{\left(58-L_{p}+i\right)} e^{\theta\left(L_{p}-i\right)} \\
& +f_{e} \sum_{i=L_{e}+1}^{L_{p}-1} A_{\left(58-L_{p+i}\right)} e^{\theta\left(L_{p}-i\right)}
\end{aligned}
$$

where

$$
A_{t}=\frac{I_{58}+I_{59}}{A g g \operatorname{In} v_{58}+\operatorname{Agg} \operatorname{In} v_{59}} \times A g g \operatorname{In} v_{\iota},
$$

and $A g g \operatorname{In} v_{t}$ is aggregate investment of nonfinancial corporations in year $t$. This procedure yields a synthetic pattern of plant and equipment investment and composition for the $L_{P}$ years before 1958 that is consistent with the firm's stated 1958 gross capital stock.

The data, actual and synthetic, are used to estimate for each year the age and composition of the capital stock for each firm. This in turn is used to compute an estimate of replacement cost in current dollars and true economic depreciation, also in current dollars. The procedure is as follows. The age structure for each year after 1958 is derived by aging the structure from the preceding year, adding new investments (from available data), subtracting estimated retirements, $R E T$, and scaling the result by writing off a portion of the stocks. Write-offs, $W O$, which include sales of plant and equipment, are therefore given by

$$
W O_{t}=G K_{t}-G K_{t+1}+I_{t}-R E T \text {. }
$$

We assume that the amount of equipment and plant plus land of each vintage written off is proportional to the existing stock. Retirements are the investments that reach terminal age without being written off. 
In addition to plant and equipment, the real physical capital of the firm includes inventories and other assets (principally interests in unconsolidated subsidiaries). The book value of inventories for firms using the last in, first out (LIFO) method of inventory valuation is significantly different from market value in times of general price inflation. Firms using the first in, first out (FIFO) method, however, state inventories at close to market value.

The inventory methods used by firms are listed on the Compustat file in order of importance. To determine the market value of inventories for those who report two methods, we assume, somewhat arbitrarily, that two-thirds of inventories are by the first of the two methods, one-third by the second. Similar fractional assumptions (one-half, one-third, one-sixth) are made when three methods are used. We keep track of the stocks of both FIFO and LIFO inventories by vintage in determining market value. If a firm liquidates inventories in a given year, we draw on both stocks according to our assumed proportions, depleting the oldest FIFO and the newest LIFO stocks first. If the firm accumulates inventories, they are allocated to LIFO and FIFO stocks in these same proportions. To implement this technique, the market value of inventories is taken to be the same as the book value in the first year of our sample, 1958.

Other assets are carried on the books of firms at historical acquisition cost and we treat them like LIFO inventories. Their market value is updated by the same technique used for LIFO inventories. Again, market value is considered to be equal to the stated value in 1958 .

\section{CALCULATING RATE OF RETURN}

Our estimate of the replacement value of the firm's physical capital stock is the sum of the current dollar value of plant and equipment net of depreciation, plus the current dollar value of inventories and other assets. Gross capital represents this replacement value (net of write-offs and retirements) without adjustment for depreciation.

Because we are interested in the total return to capital rather than the return to stockholders alone, we aggregate the following sources of capital income to determine gross cash flows: corporate (equity) net income (after corporate income tax, before extraordinary items and discontinued operations), total reported interest expense, and book-value (reported) depreciation, minus inventory valuation adjustment (for firms using FIFO 
inventory valuation), and minus the imputed interest income (prime rate applied to net short-term financial assets ).

The inventory valuation adjustment, $I V A$, excludes from earnings the capital gains on existing inventories. With a constant inventory-sales ratio this is approximately equal to the difference between the replacement cost of goods sold from inventories and the book value used to calculate earnings :

$$
I V A_{t}=M \operatorname{Inv} v_{t-1}\left(\frac{P_{t}}{P_{t-1}}-1\right) \times(\text { FIFO proportion })
$$

where $M I n v_{t-1}$ is the market value of inventories for the previous year. The price index used for this calculation is the implicit GNP deflator for inventories. Imputed interest income is subtracted so that the gross cash flow corresponds to the return to physical capital only, assuming that the valuation of financial assets can be treated independently. The returns to "good will" and other intangibles are attributed to capital.

The after-tax gross rate of return in each period is defined by

$$
r_{G}=\frac{G C F}{K_{G}},
$$

where $G C F$ is gross cash flows and $K_{G}$ is the current gross value of the plant, land, and equipment plus adjusted inventories and adjusted other assets. As previously mentioned, it is assumed that the gross rate of return in a specific year is the same for capital of all ages. Because it is assumed that the remaining life of the existing capital stock is known with certainty, the major source of uncertainty about future returns comes from uncertainty about the gross return.

The after-tax net rate of return as usually defined is only an approximation to the internal rate of return for our technology. It is given by

$$
r_{N}=\frac{G C F-A D}{K_{N}}
$$

where $A D$ is depreciation at replacement cost, calculated from the derived age structure and composition of the capital stock as described above, and $K_{N}$ is the adjusted net plant, land, and equipment, plus adjusted inventories and adjusted other assets in current dollars.

The calculations above were performed on a sample of 187 firms using Compustat income and balance sheet data for the $1958-77$ period. The 
Table 1. Annual Rates of Return on Nonfinancial Corporate Capital, 1958-77

Percent

\begin{tabular}{|c|c|c|c|c|c|c|c|}
\hline \multirow[b]{2}{*}{ Year } & \multicolumn{3}{|c|}{ Brainard-Shoven-Weiss } & \multicolumn{2}{|c|}{ Feldstein-Summers } & \multicolumn{2}{|c|}{ Nordhaus } \\
\hline & $r_{N}$ & $r_{G}$ & $R_{G}$ & $R_{N}$ & $R_{G}$ & $R_{N}$ & $r_{N}$ \\
\hline 1958 & 6.5 & 8.6 & 11.9 & 8.5 & 9.7 & 10.4 & 5.4 \\
\hline 1959 & 7.3 & 9.1 & 13.1 & 10.7 & 11.1 & 13.0 & 6.8 \\
\hline 1960 & 6.9 & 8.8 & 12.5 & 9.9 & 10.6 & 12.0 & 6.3 \\
\hline 1961 & 6.9 & 8.8 & 12.3 & 9.8 & 10.6 & 11.8 & 6.3 \\
\hline 1962 & 7.3 & 9.1 & 12.8 & 11.2 & 11.6 & 13.5 & 7.9 \\
\hline 1963 & 7.8 & 9.4 & 13.3 & 11.9 & 12.0 & 14.0 & 8.1 \\
\hline 1964 & 8.5 & 9.9 & 13.8 & 12.8 & 12.6 & 15.0 & 9.1 \\
\hline 1965 & 9.3 & 10.5 & 14.6 & 13.7 & 13.2 & 16.3 & 10.0 \\
\hline 1966 & 8.7 & 10.3 & 14.3 & 13.4 & 13.2 & 16.1 & 9.9 \\
\hline 1967 & 7.9 & 9.8 & 13.2 & 11.9 & 12.2 & 14.0 & 8.8 \\
\hline 1968 & 8.0 & 10.0 & 14.0 & 11.7 & 12.1 & 14.0 & 8.1 \\
\hline 1969 & 7.3 & 9.5 & 13.3 & 10.2 & 11.1 & 11.6 & 6.4 \\
\hline 1970 & 6.4 & 8.9 & 12.1 & 8.1 & 9.7 & 9.1 & 5.3 \\
\hline 1971 & 6.3 & 8.9 & 12.3 & 8.4 & 9.9 & 9.6 & 5.7 \\
\hline 1972 & 6.7 & 9.1 & 12.9 & 9.2 & 10.4 & 9.9 & 5.6 \\
\hline 1973 & 8.7 & 10.5 & 15.1 & 8.6 & 9.9 & 10.5 & 5.4 \\
\hline 1974 & 9.0 & 10.7 & 16.7 & 6.4 & 8.4 & $\ldots$ & $\ldots$ \\
\hline 1975 & 5.4 & 8.2 & 12.9 & 6.9 & 8.9 & $\ldots$ & $\ldots$ \\
\hline 1976 & 5.9 & 8.5 & 12.9 & 7.9 & 9.7 & $\ldots$ & $\ldots$ \\
\hline 1977 & 6.0 & 8.6 & 13.1 & $\ldots$ & $\ldots$ & $\ldots$ & $\ldots$ \\
\hline
\end{tabular}

Sources: Brainard-Shoven-Weiss-Calculations by the authors based on a sample of 187 firms selected from the Compustat tape containing income and balance sheet data. The firms selected were ones that did not merge and ones for which data were available for the entire period; Feldstein-Summers--Martin Feldstein and Lawrence Summers, "Is the Rate of Profit Falling?" BPEA, I:1977, table 1, p. 216; Nordhaus-William D. Nordhaus, "The Falling Share of Profits," BPEA, 1:1974, table 5, p. 180.

a. The net and gross rates af ter corporate income tax are $r_{N}$ and $r_{G}$, respectively; the corresponding rates before corporate income tax are $R_{N}$ and $R_{G}$.

187 firms are those in the Compustat file that did not merge and that provided all the data required by our computation procedure for the entire twenty-year period. This procedure may introduce a number of sample biases. Perhaps the most important is that those firms that have survived to the present have experienced actual earnings that, on average, exceeded investors' expectations early in the sample period. The exclusion of firms that merged is another factor that makes our sample unrepresentative of all firms, although the direction of the bias is less clear. We do not, however, explicitly evaluate these sample biases.

Table 1 displays net and gross rates of return to capital for an aggregate of the 187 firms in our sample and compares these figures with similar 
computations made by William Nordhaus and by Martin Feldstein and Lawrence Summers. The different series of the table are not strictly comparable because of different samples and definitions of return. The Feldstein-Summers figures are before corporate income tax and are derived from data on the revised national income accounts. The Nordhaus $r_{N}$ series is also based on the national income accounts but is after tax. Our series show the smallest bulge for the mid-1960s and the smallest decline in the 1970s. These differences indicate that our sample is not representative of the entire nonfinancial sector. We compared the magnitude of our inflation adjustments (inventory valuation adjustment and capital consumption adjustment) with those in the national income accounts, and the magnitudes are approximately consistent. Presumably, therefore, the differences reflect variations in reported earnings rather than in our adjustments to them.

The paradox that we explore in this paper is the fall of the market valuation of our sample of 187 firms despite the relative constancy of the calculated productivity of their capital stocks. If the rates of return for our sample were misestimated and in fact changed more like those estimated by Feldstein and Summers for the aggregate economy, there would be less of a puzzle, and this would have the effect of raising the implicit required rate of discount during the 1960s and lowering it in the 1970s.

\section{CALCULATING MARKET VALUATION}

We seek to determine the market valuation of claims to returns emanating from physical capital. The ownership claims to this flow fall into five broad groups: common stock, preferred stock, bank and bond debt, shortterm liabilities not included in bank and bond debt (principally accounts payable), and other claims (unfunded pension liabilities).

The value of common stock is taken as the year-end values from the Compustat data. Because of the difficulty in obtaining actual preferred stock prices, we calculate a firm's aggregate preferred market value by dividing its total reported preferred dividends by Moody's preferred stock yield index.

The market value of debt is more difficult to estimate. Available data decompose book-value debt, $b_{t}$, into short-term debt, $S T D_{t}$ (maturing within one year) and all other long-term debt $\left(L T D_{t}\right)$ :

$$
b_{t}=S T D_{t}+L T D_{t} .
$$


The market value of short-term debt is assumed to equal book value. To estimate the market value of long-term debt, the following assumptions were made: new bonds are issued at par and have a maturity of twenty years; bonds have identical default characteristics represented by a Baa rating; the maturity distribution of bonds for each firm in the first year of study, 1958, is proportional to the maturity distribution of aggregate outstanding issues; and no new debt is issued unless total long-term debt in $t$ is greater than long-term debt in $t-1$ minus estimated matured issuances of debt. Under these conditions, new debt issued in period $t, N_{t}$, for $t>1958$ is calculated by

$$
N_{t}=L T D_{t}-L T D_{t-1}+N_{t-19} \quad \text { if } L T D_{t}>L T D_{t-1}-N_{t-19} .
$$

If

$$
L T D_{t}<L T D_{t-1}-N_{t-19} \text {, then } N_{t}=0
$$

and

$$
N_{t-1}=\frac{L T D_{t}}{L T D_{t-1}-N_{t-19}} N_{t-1}
$$

that is, early retirements are proportional to existing issuances of debt. Given the derived maturities and associated coupon rates, the current dollar values of these debts may be computed easily. As might be expected in a period of accelerating inflation and rising interest rates, most bonds have sold at a discount from book values during 1958-77.

The sum of common and preferred stock and debt at market value is usually taken to be the market value of a firm. However, we are interested only in the market value of the underlying real stock of capital. Thus we subtract net short-term assets from this sum. This procedure is valid only if these assets can be converted readily into cash and if their market value equals stated book value. This does not appear to be too far from the truth, given the types of claims that assets include. No attempt is made to estimate the effects of unfunded pension liabilities or other contingent claims that may subordinate equity claims. This is perhaps a more serious omission.

\section{CALCULATING $q$}

Following the early work of William Brainard and James Tobin, we constructed estimates of the ratio of market value to replacement cost, $q$, for the aggregate of the 187 firms in each year. ${ }^{8}$ For comparison, we pre-

8. William C. Brainard and James Tobin, "Pitfalls in Financial Model Building," American Economic Review, vol. 58 (May 1968, Papers and Proceedings, 1967), pp. 99-122. 
Table 2. Alternative Estimates of the Aggregate Ratio of Market Value to Replacement Cost, $q$, 1958-77

\begin{tabular}{|c|c|c|c|c|c|c|}
\hline Year & $\begin{array}{c}\text { Brainard, } \\
\text { Shoven, } \\
\text { Weiss }\end{array}$ & $\begin{array}{c}\text { Economic } \\
\text { Report } \\
\text { of the } \\
\text { President }\end{array}$ & $\begin{array}{c}\text { Tobin- } \\
\text { Brainard }\end{array}$ & $\begin{array}{l}\text { Lindenberg- } \\
\quad \text { Ross }\end{array}$ & Ciccolo & $\begin{array}{c}\text { von } \\
\text { Furstenberg }\end{array}$ \\
\hline 1958 & 1.49 & 0.87 & $\ldots$ & $\ldots$ & 1.11 & 0.73 \\
\hline 1959 & 1.55 & 1.04 & $\ldots$ & $\ldots$ & 1.30 & 0.85 \\
\hline 1960 & 1.42 & 1.02 & 2.21 & 1.71 & 1.24 & 0.83 \\
\hline 1961 & 1.66 & 1.15 & 2.51 & 2.00 & 1.66 & 0.92 \\
\hline 1962 & 1.39 & 1.09 & 1.88 & 1.60 & 1.43 & 0.87 \\
\hline 1963 & 1.55 & 1.20 & 2.21 & 1.72 & 1.72 & 0.97 \\
\hline 1964 & 1.70 & 1.30 & 2.29 & 1.79 & 1.90 & 1.04 \\
\hline 1965 & 1.74 & 1.36 & 2.50 & 1.96 & 2.05 & 1.09 \\
\hline 1966 & 1.39 & 1.21 & 2.11 & 1.62 & 1.41 & 0.98 \\
\hline 1967 & 1.58 & 1.22 & 2.51 & 1.82 & 1.61 & 0.98 \\
\hline 1968 & 1.56 & 1.26 & 2.54 & 1.84 & 1.76 & 0.99 \\
\hline 1969 & 1.30 & 1.12 & 2.12 & 1.61 & 1.37 & 0.88 \\
\hline 1970 & 1.20 & 0.91 & 1.92 & 1.48 & 1.08 & 0.71 \\
\hline 1971 & 1.26 & 1.00 & 2.00 & 1.58 & 1.28 & 0.78 \\
\hline 1972 & 1.37 & 1.08 & 1.99 & 1.63 & 1.56 & 0.85 \\
\hline 1973 & 1.07 & 1.02 & 1.43 & 1.28 & 1.25 & 0.82 \\
\hline 1974 & 0.69 & 0.76 & 0.97 & 0.96 & 0.70 & 0.68 \\
\hline 1975 & 0.74 & 0.73 & $\ldots$ & 1.00 & 0.79 & 0.61 \\
\hline 1976 & 0.83 & 0.83 & $\ldots$ & 0.98 & 0.97 & 0.68 \\
\hline 1977 & 0.72 & 0.77 & $\ldots$ & 0.88 & 0.84 & $\ldots$ \\
\hline
\end{tabular}

Sources: Brainard-Shoven-Weiss-Calculations by the authors based on a sample of 187 firms selected from the Compustat data tape; Economic Report of the President-January 1979 volume, table 30, p. 128; Tobin-Brainard-James Tobin and William C. Brainard, "Asset Markets and the Cost of Capital," in Bela Balassa and Richard Nelson, eds., Economic Progress, Private Values and Public Policy, Essays in Honor of William Fellner (North-Holland, 1977), p. 254; Lindenberg-Ross-Eric B. Lindenberg and Stephen A. Ross, "Tobin's Q Rates and Industrial Organization," Journal of Business (forthcoming): Ciccolo-John H. Ciccolo, "Tobin's q and Tax Incentives," paper prepared for the 1979 Southern Financial Association Meeting; and von Furstenberg-George M. von Furstenberg, "Corporate Investment: Does Market Valuation Matter in the Aggregate?" BPEA, 2:1977, pp. 351-55.

sent similar estimates in table 2 by Tobin and Brainard, Eric Lindenberg and Stephen Ross, John Ciccolo, George von Furstenberg, and one from the Economic Report of the President, January 1979. The Tobin-Brainard and Lindenberg-Ross studies both use the data on firms from the Compustat data base whereas the other studies use aggregate data. The various estimates show significantly different levels-which are difficult to reconcile-but nevertheless show similar patterns through time. 


\section{FORECASTING FUTURE EARNINGS}

To calculate the two intrinsic values described above-cash-out and constant-capital cases-we seek to determine, for each firm in each year, the present value of discounted future gross cash flows. This requires both an estimate of these uncertain, multiperiod cash flows and a method of valuation.

For these calculations we assume that the firm will operate all existing capital until the end of its lifetime, when it will be discarded without scrap value. In the constant-capital case each unit of capital is replaced, whereas for the cash-out case, it is not. Each unit of capital operating at a particular time receives the same return. As noted earlier, we estimate the productive lifetimes of capital (separately for plant, and equipment plus land, when possible) from the Security Exchange Commission 10-K reports for 1975. From our estimate of the composition and age structure of the capital stock for each firm and each year we derive an estimate of the fraction of the original capital existing at time $t$ that will be operational $\tau$ periods later $\left(D_{t+\tau}\right)$.

Some physical assets, inventories, and other assets (including investments in stock, unconsolidated subsidiaries, long-term receivables) do not depreciate or become obsolete. In the cash-out calculation these assets are taken to be liquidated at inflation-corrected book value so that they remain the same fraction of total assets as they were in the base year. That is, in each year $\tau$, a fraction $D_{t+\tau}-D_{t+\tau_{+1}}$ of these assets is sold.

Thus in the cash-out case the returns $\tau$ years in the future associated with a firm with capital stock (including inventories and other assets), $K_{t}$, at time $t$ are given by:

$$
R_{t+\tau}^{A} K_{t} D_{t+\tau}+\left(\begin{array}{c}
\text { inventories and } \\
\text { other assets }
\end{array}\right)\left(D_{t+\tau}-D_{t+\tau+1}\right),
$$

where $R_{t+\tau}^{A}$ is the random rate of return for the firm $\tau$ periods hence, gross of depreciation, net of corporate tax. The future returns for the constantcapital case correspond to this equation with all $D$ set at unity. The estimates of $R_{t+\tau}^{A}$ are constructed by separately estimating before-tax rates of return and future effective taxes. The before-tax rates are assumed to be generated by stationary real processes, whereas the nonneutral effect of inflation on the real value of depreciation and interest is taken into account when calculating the taxes. 
Several different methods of the expected before-tax future rates of return, $R_{t}$, are constructed. Each corresponds to a different way investors might model the process generating rates of return. All these models depict stationary processes, so that past outcomes provide a guide to future values. In the first three models the expected future before-tax gross return depends only on past returns; the market valuation or other firm characteristics are not used in the forecast. The models are as follows.

(1) A pure random walk-the expected rate of return in each future period is the current realization. If this is what investors assume, no other information should improve the implied estimates of market values.

(2) A first-order autoregressive process - the rate of return for each firm is governed by

$$
R_{l}=\alpha+\lambda R_{t-1}+\tilde{\epsilon}_{l}
$$

Estimates for $\alpha$ and $\lambda$ were obtained from regression equations for the entire time series and were used to construct an estimate of the return $\tau$ periods in the future:

$$
E\left(R_{1+\tau}\right)=\frac{\left(1-\lambda^{\tau}\right)}{(1-\lambda)} \alpha+\lambda^{\tau} R_{\iota}
$$

(3) Perfect foresight - the expected rate of return held by market participants is assumed to be the actual outcome for all realizations for which data are available, that is, before 1977. The estimates after 1977 are from (2) above.

The next three models decompose the gross rate of return for each firm into two component parts. One component, $\beta, R_{m t}$, is perfectly correlated with the aggregate gross rate of return, $R_{m t}$, as estimated by Feldstein and Summers and reproduced here in the fourth column of table $1 .{ }^{9}$ The other component, $\hat{r}_{t}$, is independent of the aggregate rate. These procedures therefore require estimates of the relation of the firm's return to the aggregate, and predictions of both $\hat{r}_{t}$ and $R_{m t}$. The following equation was estimated for each of 187 firms using the entire sample period:

$$
R_{j t}=\beta_{o j}+\beta_{\jmath} R_{m t}+\tilde{\epsilon}_{j t}=\hat{r}_{j t}+\beta_{\jmath} R_{m t} .
$$

To determine the extent to which our results are sensitive to the assumption that the relation between a firm's gross rate of return and the aggregate

9. Martin Feldstein and Lawrence Summers, "Is the Rate of Profit Falling?" BPEA , 1:1977, table 1, p. 216. 
return is constant, the equation is also estimated separately on the two halves of the sample period. In general, the $\beta$ coefficients differ substantially in the two subperiods.

The three procedures that separate the return each assume that $\hat{r}_{t}$ follows a random walk but make different assumptions about the process generating $R_{m}$. We therefore know that

$$
E\left(R_{j l+\tau}\right)=\hat{r}_{j t}+\beta_{j} E\left(R_{m t+\tau}\right)
$$

The methods are as follows.

(4) Random walk for $\hat{r}_{t}$, autoregressive process for $R_{m t}$-a regression equation was estimated,

$$
\begin{gathered}
R_{m t}=0.019+0.83 R_{m t-1}+\epsilon_{m t}, \\
R^{2}=0.68 ; \text { standard error }=0.0082 ; \text { Durbin-Watson }=1.33 .
\end{gathered}
$$

Thus

$$
E\left(R_{m++\tau}\right)=\frac{1-(0.83)^{\tau}}{1-(0.83)} 0.019+(0.83)^{\tau} R_{m t} .
$$

(5) Random walk for $\hat{r}_{t}$, perfect foresight $R_{m}$ - for the period outside the sample, model 4 was used for $R_{m t}$.

(6) Random walk for $\hat{r}_{t}, R_{m t}$ distributed independently and identically over time-E $\left(R_{m t}\right)=0.1083$, the overall sample mean for 1958-77.

The above three models actually formed six cases because they are implemented once using the $\beta$ estimates determined from the entire sample, and a second time using separate $\beta$ estimates for each half of the period.

(7) The final procedure uses information generally available to investors to predict future gross flows. Regressions are estimated on the pooled time-series observations to predict rates of return one, three, and five years in the future. The predictions for years two and four are linear interpolations of one and three, and three and five, respectively. Prediction of returns for five years are used for each year past the fifth year. Thus the typical regression equation is

$$
\begin{array}{rl}
R_{t+n}=\alpha_{0}+\alpha_{1} R_{t}+\alpha_{2} & R D I V_{\imath}+\alpha_{3} C D I V_{\imath}+\alpha_{4} R I N V_{\imath} \\
& +\alpha_{5} q_{t}+\alpha_{6} C q_{t}+\alpha_{7} C S_{t}+\alpha_{8} R D E P_{t}+\epsilon_{\imath+n},
\end{array}
$$

where

$$
R_{t}=\text { gross rate of return in year } t
$$

$R D I V_{t}=$ dividends divided by before-tax gross cash flow 


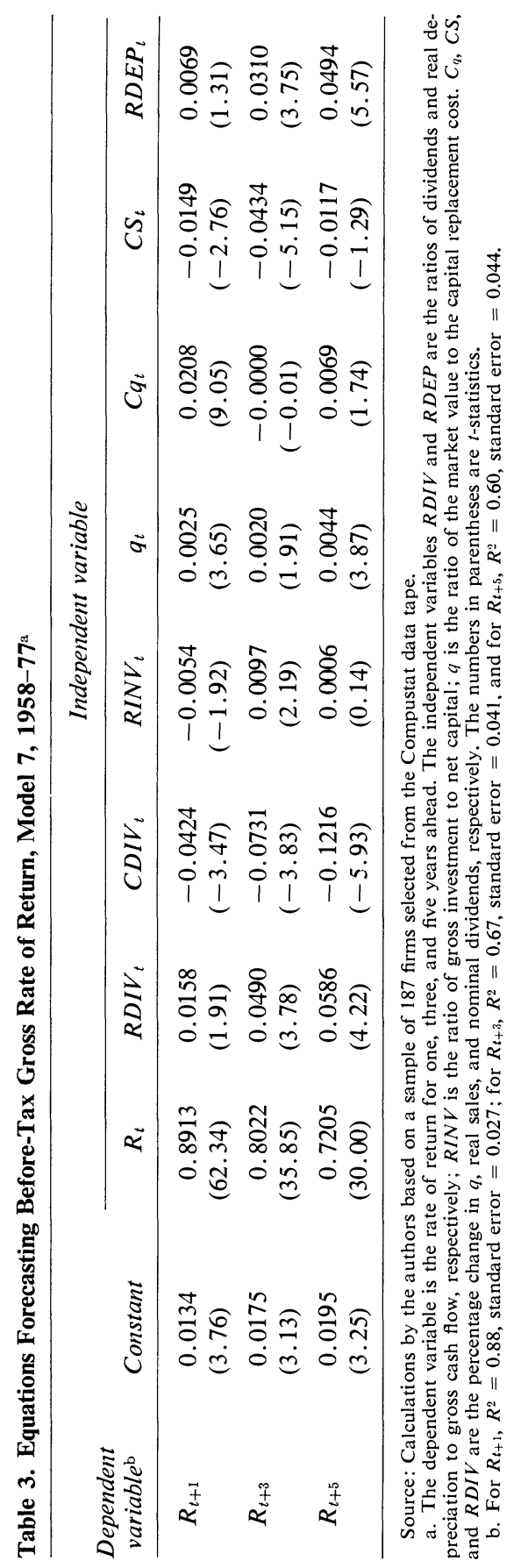


$C D I V_{1}=$ percentage change in nominal dividends from $t-1$ to $t$ $R I N V_{t}=$ gross investment divided by net capital

$q_{t}=$ market value divided by replacement cost of capital

$C q_{t}=$ percentage change in $q$ from $t-1$ to $t$

$C S_{t}=$ percentage change in real sales from $t-1$ to $t$

$R D E P_{t}=$ real depreciation divided by before-tax gross cash flow

Dividend payments and changes in dividends are regarded as conveying information about permanent earnings. Similarly, investment provides information about management's view of future profitability. A firm's $q$ and change in $q$ provide an investor with the market's assessment of the future earnings potential of a firm. A high $q$, for example, can indicate the existence of profit opportunities that have not yet appeared in current earnings or sales. Real depreciation may be important in predicting the gross rate of return because in equilibrium firms with high rates of depreciation will have high gross rates.

The results from estimating regressions on the gross rate for the entire sample period are reported in table 3. The average data for the rate-ofreturn regression equations are shown in table 4 . The three equations look surprisingly sensible. The current rate of return is of great, but declining, significance in forecasting future rates. Dividends are also significant, and their importance in prediction increases the further the forecast is into the future. The negative coefficient on CDIV seems consistent with the view that dividends are increased when the value of retention is low. In the short run, investment appears to affect the rate of return negatively, possibly reflecting the fact that it increases the capital stock before raising revenues. Investment does seem to be positively related to returns after three years, but only weakly related to earnings further into the future. The level of $q$ does indeed seem to provide information about future earnings. One plausible interpretation of the negative coefficient for change in real sales is that changes in sales only give rise to transitory earnings.

\section{DISCOUNTING FUTURE EARNINGS}

Computations of intrinsic values require not only a projection of uncertain future gross cash flows, but a method of valuing them. We compute the intrinsic values implied by discounting the expected future returns by three different discount rates: an inflation-adjusted bond rate, zero per- 
Table 4. Average Values of the Variables in Rate of Return Regressions, Model 7, 1958-77

Percent, except as noted

\begin{tabular}{rrrrrrrrr}
\hline & \multicolumn{7}{c}{ Independent variable } \\
\cline { 2 - 9 } Year & \multicolumn{1}{c}{$R_{t}$} & $R D I V$ & $C D I V$ & $R I N V$ & $q($ ratio $)$ & \multicolumn{1}{c}{$C q$} & $C S$ & $R D E P$ \\
\hline 1958 & 15.8 & 19.5 & 0.0 & 8.7 & 1.59 & $\ldots$ & $\ldots$ & 34.6 \\
1959 & 17.3 & 17.6 & 13.2 & 8.8 & 1.80 & 9.1 & 12.0 & 29.8 \\
1960 & 16.0 & 19.3 & 7.7 & 9.6 & 1.74 & -0.7 & 3.7 & 32.3 \\
1961 & 15.6 & 19.3 & 4.7 & 8.1 & 1.99 & 15.5 & 3.5 & 31.9 \\
1962 & 16.1 & 18.8 & 7.0 & 8.4 & 1.51 & -22.9 & 7.9 & 31.2 \\
1963 & 16.3 & 18.0 & 6.5 & 8.7 & 1.59 & 7.2 & 6.4 & 29.5 \\
1964 & 17.2 & 17.3 & 10.5 & 9.2 & 1.71 & 8.5 & 9.9 & 27.4 \\
1965 & 18.1 & 16.8 & 13.4 & 10.5 & 1.90 & 9.5 & 10.8 & 25.8 \\
1966 & 17.6 & 17.1 & 12.9 & 11.8 & 1.51 & -23.2 & 9.3 & 26.0 \\
1967 & 16.2 & 18.4 & 9.5 & 10.7 & 1.83 & 16.6 & 5.1 & 29.1 \\
1968 & 16.7 & 17.0 & 6.8 & 9.7 & 1.85 & 5.1 & 8.1 & 28.2 \\
1969 & 16.2 & 16.3 & 5.7 & 10.1 & 1.56 & -23.5 & 6.6 & 29.2 \\
1970 & 14.1 & 17.2 & 2.2 & 9.3 & 1.37 & -10.4 & 0.5 & 34.0 \\
1971 & 13.8 & 16.0 & -0.1 & 8.4 & 1.50 & 6.4 & 2.4 & 35.1 \\
1972 & 14.5 & 13.9 & 2.8 & 7.9 & 1.59 & 0.8 & 8.0 & 32.7 \\
1973 & 16.4 & 11.7 & 11.0 & 8.9 & 1.16 & -29.8 & 11.1 & 27.7 \\
1974 & 16.3 & 11.4 & 12.8 & 9.4 & 0.75 & -35.6 & 11.1 & 28.0 \\
1975 & 13.0 & 13.5 & 5.5 & 8.0 & 0.82 & 9.8 & -5.1 & 38.1 \\
1976 & 13.9 & 12.4 & 12.7 & 7.9 & 0.90 & 13.0 & 7.0 & 35.3 \\
1977 & 14.1 & 13.0 & 16.2 & 8.4 & 0.78 & -11.0 & 6.3 & 35.2 \\
\hline
\end{tabular}

Source: Same as table 3.

cent real rate, and 4 percent real rate. We also calculate the internal rate of return-the discount rate that equates the discounted value of cash payouts with the market value for the aggregate of our sample. These calculations were made without adjustment for risk, and would be appropriate in a risk-neutral world. In the next section we return to a discussion of risk and our treatment of risk premiums.

The term structure of real discount rates corresponding to the first measure is constructed as follows: first, from available data on yield to maturity of government bonds, an estimate is made of the term structure of the discount rates appropriate for discounting dollar returns arriving at specified dates in the future. The expected inflation rate generated by a weighted moving average of past inflation is subtracted from the discount rates. The weights for this calculation are $1 / 2,1 / 3$, and $1 / 6$. Table 5 presents 
Table 5. Inflation Projections and Term Structures of Discount Rates, 1958-77

Percent

\begin{tabular}{ccccccc}
\hline & \multirow{6}{*}{$\begin{array}{c}\text { Projected } \\
\text { percentage } \\
\text { change in }\end{array}$} & \multicolumn{5}{c}{ Nominal discount rate } \\
\cline { 3 - 7 } Year & $\begin{array}{c}\text { One } \\
\text { GNP deflator }\end{array}$ & year & $\begin{array}{c}\text { Two } \\
\text { years }\end{array}$ & $\begin{array}{c}\text { Five } \\
\text { years }\end{array}$ & $\begin{array}{c}\text { Ten } \\
\text { years }\end{array}$ & $\begin{array}{c}\text { Twenty } \\
\text { years }\end{array}$ \\
\hline 1958 & 2.77 & 2.09 & 2.36 & 2.99 & 3.34 & 3.50 \\
1959 & 2.32 & 4.11 & 4.18 & 4.30 & 4.12 & 4.04 \\
1960 & 2.02 & 3.55 & 3.70 & 4.00 & 4.01 & 4.02 \\
1961 & 1.62 & 2.91 & 3.14 & 3.66 & 3.86 & 3.95 \\
1962 & 1.44 & 3.02 & 3.21 & 3.64 & 3.89 & 4.00 \\
1963 & 1.50 & 3.28 & 3.43 & 3.77 & 3.96 & 4.04 \\
1964 & 1.54 & 3.76 & 3.86 & 4.08 & 4.14 & 4.17 \\
1965 & 1.73 & 4.09 & 4.13 & 4.22 & 4.21 & 4.21 \\
1966 & 2.26 & 5.17 & 5.17 & 5.09 & 4.73 & 4.59 \\
1967 & 2.79 & 4.84 & 4.92 & 5.05 & 4.89 & 4.82 \\
1968 & 3.36 & 5.62 & 5.61 & 5.54 & 5.30 & 5.19 \\
1969 & 4.14 & 7.06 & 6.99 & 6.73 & 6.18 & 5.95 \\
1970 & 4.81 & 6.90 & 7.06 & 7.28 & 6.68 & 6.43 \\
1971 & 5.14 & 4.75 & 5.10 & 5.81 & 5.76 & 5.75 \\
1972 & 4.91 & 4.86 & 5.20 & 5.86 & 5.68 & 5.60 \\
1973 & 4.90 & 7.30 & 7.17 & 6.82 & 6.36 & 6.16 \\
1974 & 6.32 & 8.25 & 8.10 & 7.67 & 7.06 & 6.79 \\
1975 & 8.24 & 6.70 & 6.99 & 7.51 & 7.05 & 6.86 \\
1976 & 8.15 & 5.94 & 6.28 & 6.96 & 6.82 & 6.76 \\
1977 & 6.81 & 6.15 & 6.39 & 6.91 & 7.06 & 7.13 \\
\hline
\end{tabular}

Sources: GNP deflator calculations based on data from Economic Report of the President, 1980, table B-3, p. 206; calculations of discount rates based on data from the Board of Governors of the Federal Reserve System.

a. The rate for discounting a dollar amount to be delivered at a specified future date. Computed from the yields on U.S. government bonds.

b. Calculated as a moving average of past inflation, with weights of one-half, one-third, and one-sixth.

the implied estimates of expected future inflation and nominal discount rates.

For each of the ten cash-flow projection models, the intrinsic value of each firm in each year is computed using the three different discount measures. Aggregating over the 187 firms in each year yields estimates of aggregate intrinsic value. Aggregate $Z$ is the ratio of aggregate market value to aggregate intrinsic value. The values of $Z$ for each projection model in each year are presented in table 6 .

The dramatic decline in the financial market's valuation of firms relative to underlying cash flows is evident for all three discount measures. For the calculations using inflation-adjusted government bond rates, the 
Table 6. Ratio of Aggregate Market Value to Intrinsic Value, for All Firms, with Three Different Discount Rates and for Ten Cash-Out Projection Models, 1958-77

\begin{tabular}{|c|c|c|c|c|c|c|c|c|c|c|}
\hline \multirow[b]{2}{*}{ Year } & \multicolumn{10}{|c|}{ Model } \\
\hline & 1 & 2 & 3 & 4 & 5 & 6 & 7 & 8 & 9 & 10 \\
\hline \multicolumn{11}{|c|}{ Inflation-adjusted government bond rate } \\
\hline 1958 & 0.80 & 0.79 & 0.80 & 0.79 & 0.82 & 0.80 & 0.73 & 0.78 & 0.78 & 0.78 \\
\hline 1959 & 0.92 & 0.90 & 0.88 & 0.88 & 0.90 & 0.88 & 0.83 & 0.88 & 0.89 & 0.88 \\
\hline 1960 & 0.85 & 0.84 & 0.85 & 0.85 & 0.86 & 0.85 & 0.80 & 0.84 & 0.84 & 0.84 \\
\hline 1961 & 1.01 & 1.00 & 1.02 & 1.02 & 1.03 & 1.02 & 0.93 & 1.02 & 1.01 & 1.02 \\
\hline 1962 & 0.84 & 0.84 & 0.84 & 0.85 & 0.85 & 0.85 & 0.80 & 0.85 & 0.85 & 0.86 \\
\hline 1963 & 0.94 & 0.93 & 0.92 & 0.92 & 0.93 & 0.92 & 0.87 & 0.93 & 0.94 & 0.94 \\
\hline 1964 & 1.03 & 1.01 & 0.98 & 0.99 & 1.00 & 0.99 & 0.95 & 1.00 & 1.03 & 1.02 \\
\hline 1965 & 1.05 & 1.02 & 0.96 & 0.97 & 0.99 & 0.97 & 0.95 & 0.98 & 1.02 & 1.00 \\
\hline 1966 & 0.85 & 0.82 & 0.78 & 0.80 & 0.81 & 0.80 & 0.79 & 0.80 & 0.84 & 0.82 \\
\hline 1967 & 0.93 & 0.91 & 0.92 & 0.93 & 0.93 & 0.94 & 0.88 & 0.94 & 0.95 & 0.95 \\
\hline 1968 & 0.92 & 0.89 & 0.87 & 0.89 & 0.90 & 0.89 & 0.85 & 0.86 & 0.86 & 0.86 \\
\hline 1969 & 0.78 & 0.77 & 0.78 & 0.78 & 0.78 & 0.78 & 0.75 & 0.77 & 0.76 & 0.77 \\
\hline 1970 & 0.71 & 0.71 & 0.77 & 0.76 & 0.74 & 0.75 & 0.70 & 0.78 & 0.74 & 0.78 \\
\hline 1971 & 0.66 & 0.66 & 0.72 & 0.70 & 0.69 & 0.70 & 0.65 & 0.72 & 0.68 & 0.72 \\
\hline 1972 & 0.73 & 0.73 & 0.76 & 0.75 & 0.75 & 0.75 & 0.71 & 0.76 & 0.74 & 0.76 \\
\hline 1973 & 0.61 & 0.59 & 0.57 & 0.56 & 0.59 & 0.56 & 0.58 & 0.57 & 0.59 & 0.57 \\
\hline 1974 & 0.38 & 0.36 & 0.33 & 0.32 & 0.35 & 0.31 & 0.36 & 0.33 & 0.35 & 0.33 \\
\hline 1975 & 0.34 & 0.34 & 0.37 & 0.35 & 0.34 & 0.34 & 0.34 & 0.36 & 0.34 & 0.36 \\
\hline 1976 & 0.38 & 0.38 & 0.40 & 0.39 & 0.44 & 0.39 & 0.38 & 0.40 & 0.44 & 0.39 \\
\hline 1977 & 0.38 & 0.38 & 0.41 & 0.39 & 0.38 & 0.39 & 0.38 & 0.40 & 0.38 & 0.40 \\
\hline
\end{tabular}

Zero percent real discount rate

$\begin{array}{lllllllllll}1958 & 0.75 & 0.74 & 0.75 & 0.74 & 0.77 & 0.75 & 0.69 & 0.73 & 0.73 & 0.73 \\ 1959 & 0.78 & 0.76 & 0.73 & 0.73 & 0.75 & 0.73 & 0.69 & 0.73 & 0.74 & 0.74 \\ 1960 & 0.71 & 0.69 & 0.69 & 0.69 & 0.71 & 0.69 & 0.65 & 0.69 & 0.69 & 0.69 \\ 1961 & 0.82 & 0.81 & 0.82 & 0.82 & 0.83 & 0.82 & 0.74 & 0.82 & 0.81 & 0.82 \\ 1962 & 0.67 & 0.66 & 0.66 & 0.67 & 0.67 & 0.67 & 0.62 & 0.67 & 0.67 & 0.67 \\ 1963 & 0.74 & 0.73 & 0.72 & 0.72 & 0.73 & 0.72 & 0.68 & 0.73 & 0.74 & 0.74 \\ 1964 & 0.81 & 0.79 & 0.76 & 0.77 & 0.79 & 0.77 & 0.73 & 0.78 & 0.80 & 0.79 \\ 1965 & 0.83 & 0.80 & 0.75 & 0.76 & 0.78 & 0.77 & 0.74 & 0.77 & 0.80 & 0.78 \\ 1966 & 0.67 & 0.65 & 0.61 & 0.63 & 0.64 & 0.63 & 0.62 & 0.63 & 0.66 & 0.64 \\ 1967 & 0.76 & 0.74 & 0.75 & 0.76 & 0.76 & 0.76 & 0.71 & 0.76 & 0.77 & 0.77 \\ 1968 & 0.76 & 0.74 & 0.72 & 0.73 & 0.74 & 0.74 & 0.70 & 0.72 & 0.71 & 0.71 \\ 1969 & 0.64 & 0.63 & 0.64 & 0.64 & 0.64 & 0.64 & 0.61 & 0.64 & 0.63 & 0.63 \\ 1970 & 0.59 & 0.59 & 0.64 & 0.63 & 0.61 & 0.63 & 0.58 & 0.65 & 0.61 & 0.65 \\ 1971 & 0.62 & 0.62 & 0.68 & 0.66 & 0.64 & 0.66 & 0.61 & 0.68 & 0.64 & 0.68 \\ 1972 & 0.68 & 0.67 & 0.71 & 0.70 & 0.69 & 0.70 & 0.66 & 0.71 & 0.68 & 0.71 \\ 1973 & 0.53 & 0.51 & 0.49 & 0.48 & 0.51 & 0.48 & 0.50 & 0.49 & 0.51 & 0.49\end{array}$


Table 6 (continued)

\begin{tabular}{|c|c|c|c|c|c|c|c|c|c|c|}
\hline \multirow[b]{2}{*}{ Year } & \multicolumn{10}{|c|}{ Model } \\
\hline & 1 & 2 & 3 & 4 & 5 & 6 & 7 & 8 & 9 & 10 \\
\hline 1974 & 0.36 & 0.34 & 0.31 & 0.30 & 0.33 & 0.29 & 0.33 & 0.30 & 0.33 & 0.30 \\
\hline 1975 & 0.40 & 0.39 & 0.42 & 0.40 & 0.39 & 0.40 & 0.40 & 0.41 & 0.39 & 0.41 \\
\hline 1976 & 0.44 & 0.44 & 0.47 & 0.45 & 0.51 & 0.45 & 0.44 & 0.46 & 0.51 & 0.46 \\
\hline 1977 & 0.37 & 0.37 & 0.40 & 0.38 & 0.37 & 0.38 & 0.37 & 0.39 & 0.37 & 0.39 \\
\hline \multicolumn{11}{|c|}{ Four percent real discount rate } \\
\hline 1958 & 1.07 & 1.06 & 1.09 & 1.09 & 1.11 & 1.09 & 1.00 & 1.07 & 1.05 & 1.06 \\
\hline 1959 & 1.11 & 1.08 & 1.06 & 1.06 & 1.08 & 1.06 & 1.01 & 1.07 & 1.07 & 1.07 \\
\hline 1960 & 1.01 & 1.00 & 1.01 & 1.01 & 1.02 & 1.01 & 0.95 & 1.00 & 1.00 & 1.00 \\
\hline 1961 & 1.17 & 1.16 & 1.19 & 1.19 & 1.20 & 1.19 & 1.09 & 1.19 & 1.17 & 1.18 \\
\hline 1962 & 0.95 & 0.95 & 0.96 & 0.96 & 0.97 & 0.96 & 0.91 & 0.97 & 0.97 & 0.98 \\
\hline 1963 & 1.06 & 1.05 & 1.04 & 1.05 & 1.06 & 1.05 & 0.99 & 1.06 & 1.06 & 1.07 \\
\hline 1964 & 1.16 & 1.14 & 1.11 & 1.12 & 1.13 & 1.12 & 1.07 & 1.13 & 1.15 & 1.15 \\
\hline 1965 & 1.19 & 1.16 & 1.09 & 1.10 & 1.12 & 1.11 & 1.08 & 1.12 & 1.16 & 1.14 \\
\hline 1966 & 0.96 & 0.93 & 0.89 & 0.91 & 0.92 & 0.91 & 0.90 & 0.92 & 0.95 & 0.94 \\
\hline 1967 & 1.09 & 1.07 & 1.08 & 1.10 & 1.10 & 1.10 & 1.04 & 1.10 & 1.12 & 1.12 \\
\hline 1968 & 1.09 & 1.06 & 1.04 & 1.06 & 1.07 & 1.06 & 1.01 & 1.03 & 1.02 & 1.02 \\
\hline 1969 & 0.92 & 0.91 & 0.92 & 0.92 & 0.93 & 0.92 & 0.89 & 0.92 & 0.90 & 0.92 \\
\hline 1970 & 0.85 & 0.86 & 0.93 & 0.91 & 0.89 & 0.91 & 0.84 & 0.94 & 0.89 & 0.94 \\
\hline 1971 & 0.89 & 0.90 & 0.97 & 0.95 & 0.93 & 0.95 & 0.88 & 0.98 & 0.93 & 0.98 \\
\hline 1972 & 0.97 & 0.97 & 1.02 & 1.01 & 1.00 & 1.01 & 0.95 & 1.02 & 0.99 & 1.02 \\
\hline 1973 & 0.77 & 0.74 & 0.71 & 0.70 & 0.74 & 0.70 & 0.73 & 0.71 & 0.73 & 0.71 \\
\hline 1974 & 0.52 & 0.48 & 0.44 & 0.43 & 0.47 & 0.42 & 0.48 & 0.44 & 0.47 & 0.44 \\
\hline 1975 & 0.57 & 0.56 & 0.60 & 0.58 & 0.56 & 0.57 & 0.57 & 0.59 & 0.56 & 0.59 \\
\hline 1976 & 0.64 & 0.63 & 0.67 & 0.65 & 0.76 & 0.64 & 0.64 & 0.66 & 0.76 & 0.66 \\
\hline 1977 & 0.54 & 0.54 & 0.57 & 0.55 & 0.54 & 0.55 & 0.54 & 0.56 & 0.54 & 0.56 \\
\hline
\end{tabular}

Source: Calculations by the authors, as described in the text.

a. The cash-out case assumes that the value of a firm reflects only the returns on existing capital. The earnings projection models are 1-perfect foresight; 2-first order autoregressive; 3-random walk; 4- $\hat{r}_{t}$ random walk, $R_{m}$ first-order autoregressive, full sample $\beta ; 5-\hat{r}_{t}$ random walk, $R_{m}$ perfect foresight, full sample $\beta ; 6-\hat{r}_{t}$ random walk, $R_{m}=\bar{R}$, full sample $\beta ; 7-R_{\imath}$ regression; 8 -same as model 4 , split $\beta ; 9-$ same as model 5 , split $\beta$; and 10-same as model 6 , split $\beta$.

aggregate market value was within 15 percent of the present value of cash flows for the years 1961 through 1968. However, there is a dramatic break after 1972; values averaged only approximately 40 percent of our calculated intrinsic values for 1974-78. The change in the $Z$ ratios through time is far greater than it is among the models; each of our ten methods of projecting rates of return yield similar present discounted values and $Z$. Qualitatively, the results are similar for the other discount rates. 


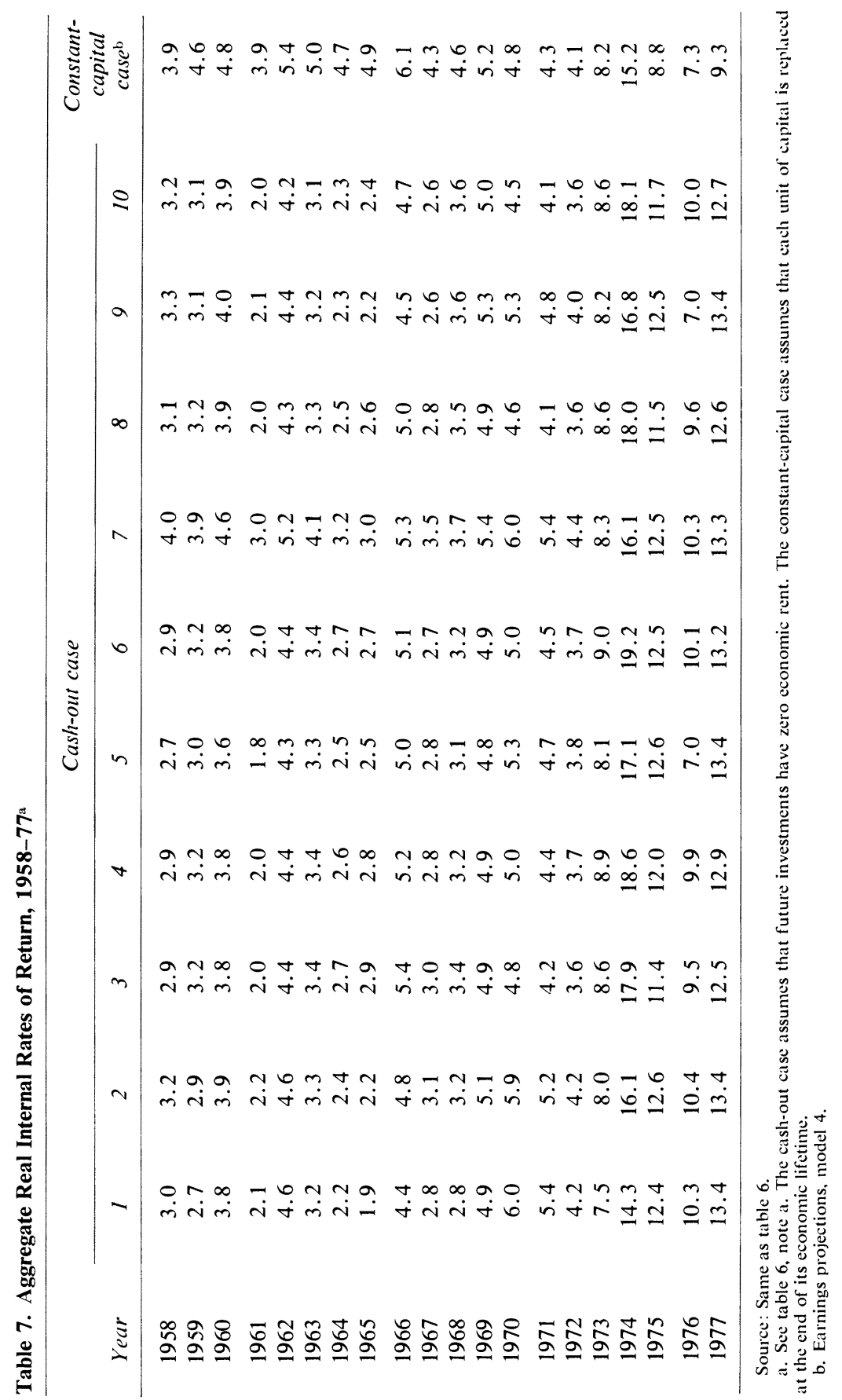


Tables 7 and 8 illustrate much the same story from slightly different perspectives. The first of these contains the real internal rates of return necessary in order to discount aggregate cash flows to aggregate market value. While these internal rates ranged roughly from 2 to 6 percent for the 1960s, they vary between 7 and 19 percent for 1974-77. This dramatic increase in internal rate is independent of which rate-of-return projection method is chosen.

Comparison of the internal rate of return for the cash-out and constantcapital assumptions is also informative. The relevant comparison is between model 4 and the constant-capital case, which assume the same earnings projection. Through 1969 the internal rate for the constantcapital case is always above the internal rate for the cash-out case. That is, the present value of the typical firm is higher if it remains in business and replaces capital as it wears out. From 1973 on, the internal rate is higher for the cash-out case-according to our calculations new investment is on average unprofitable at the discount rate implied in the valuation of existing capital.

Table 8 presents the distribution of firms by their $Z$ values in the cashout case, where forecasts of rates of return are based on model 4 and the inflation-adjusted government bond rate is used for discounting. The table shows that there was a tremendous reduction and compression of the distribution in the 1970s with only a single firm having a market valuation more than 125 percent of intrinsic value between 1975 and 1977. In contrast, in 1965 over 15 percent of our 187 firms showed $Z$ in excess of 1.25 .

The behavior of the aggregate $Z$ and the internal rate of return in the 1970 s clearly indicates that real discount rates computed as nominal rates minus expected inflation, no matter how estimated, will be unsuccessful in explaining firms' market values as the present discounted value of the future earnings we project. Indeed, the aggregate internal rate-of-return series more closely resembles an unadjusted nominal rate than anyone's estimate of the real rate. One possibility is severe inflation illusion in the discounting of real corporate cash flows; equivalently, the market may not believe that real before-tax corporate cash flows will be maintained with continued inflation. Another hypothesis is that the return to capital has become riskier and that the market price of risk has risen. In the next section we discuss the measurement of risk and the use of cross-sectional data to measure its market price. 


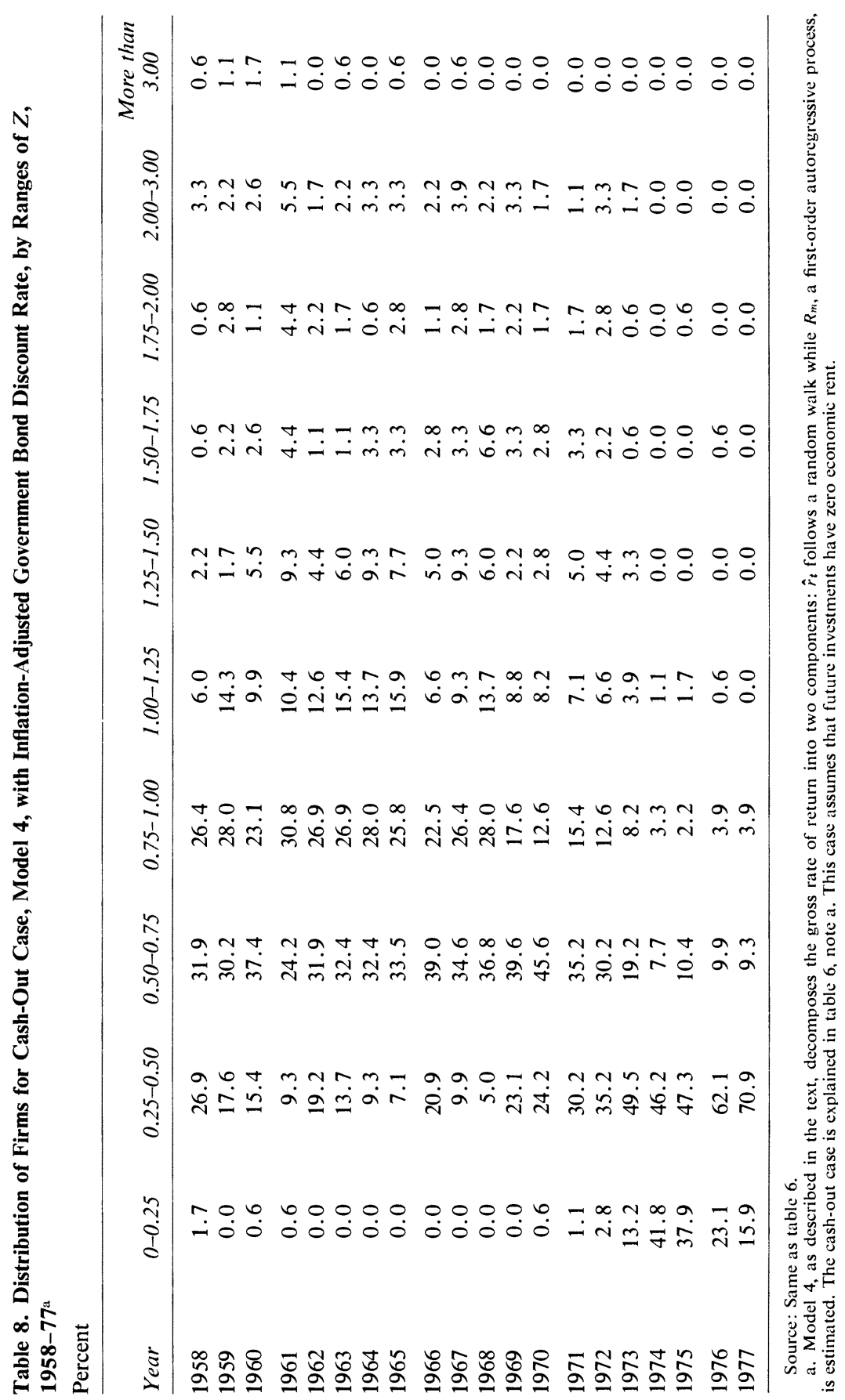




\section{MEASUREMENT AND VALUATION OF RISK}

The determination of the value of a risky stream of payments can be decomposed into two steps: time discounting to determine the present dollar equivalent of future (certain) dollar amounts, and risk discounting to determine the certainty equivalent payout for each future period. We rely on the measures of risk suggested by the familiar Sharpe-Lintner-Black capital-asset pricing model (CAPM).$^{10}$ This model draws a sharp distinction between diversifiable and systematic risk. Based on the assumption that investors seek to hold mean-variance efficient portfolios, the theory implies that risks which will disappear in well-diversified portfolios (diversifiable risks) will not require a premium over the risk-free rate.

The systematic risk of an asset measures its contribution to the riskiness of the investor's entire portfolio and therefore requires a risk premium. This contribution reflects the covariance of the asset's return with the return on the investor's entire portfolio. According to the CAPM, this covariance is the same as the covariance with the "market portfolio." This reflects the fact that in the presence of a riskless asset, each investor holds risky assets in proportion to their importance in the overall market. More precisely, the model characterizes the condition for market equilibrium by the risk-return equation:

$$
E\left(R_{i t}\right)=R_{f t}+\beta_{i}\left(E\left(R_{m t}\right)-R_{f t}\right)
$$

where

$$
\begin{aligned}
E\left(R_{i t}\right) & =\text { expected return on any security or portfolio } i \text { from } t-1 \text { to } t \\
\beta_{i} & =\operatorname{cov}\left(R_{i t}, R_{m t}\right) / \sigma^{2}\left(R_{m t}\right) \\
R_{f t} & =\text { risk-free rate from } t-1 \text { to } t \\
E\left(R_{m t}\right) & =\text { expected return on the market portfolio. }
\end{aligned}
$$

The $\beta$ in these equations are the same coefficients that govern rate-ofreturn forecasts in models 4,5 , and 6 .

10. The CAPM was developed by William Sharpe and John Lintner and later extended by Fisher Black. See William F. Sharpe, "Capital Asset Prices: A Theory of Market Equilibrium under Conditions of Risk," The Journal of Finance, vol. 19 (September 1964), pp. 425-42; John Lintner, "The Valuation of Risk Assets and the Selection of Risky Investments in Stock Portfolios and Capital Budgets," Review of Economics and Statistics, vol. 47 (February 1965), pp. 13-37; and Fisher Black, "Capital Market Equilibrium with Restricted Borrowing," Journal of Business, vol. 45 (July 1972), pp. 444-54. 
One difficulty in implementing the CAPM is identifying the market portfolio that appears in equation 1. We assume that the relevant portfolio is the nonfinancial corporate capital stock and that the market return is the return on that stock. Hence the risk measures are fundamental; they are related to the firm's cash flows, including interest, rather than to the investors' yield (dividends plus capital gains) that is usually the focus of studies of the stock market. A second difficulty in implementing the theory is extending it to value assets whose returns are distributed over future periods. The approach we use is a variation of the model proposed by Douglas Breeden. ${ }^{11}$

As in the CAPM, it is assumed that individuals maximize expected utility, and that utility can be expressed as

$$
W_{t}=\sum_{j=t}^{\infty} d(j, t) U\left(C_{j}\right)
$$

where $d(j, t)$ is the subjective time discount factor for $j$ to $t$. For a security of value, $V_{i}$, yielding a stream of uncertain cash payouts, $D_{i t}$, an optimizing investor's first-order conditions for a maximum are

$$
U^{\prime}\left(C_{t}\right) V_{i t}=E\left(\sum_{j=t}^{\infty} d(j, t) U^{\prime}\left(C_{j}\right) D_{i j}\right),
$$

where $C_{j}$ is consumption at time $j$.

If the function $U$ is quadratic, or if continuous time trading is permitted, equation 2 may be expressed as

$$
V_{i t}=\sum_{j=t}^{\infty} \frac{E\left(D_{i j}\right)-\gamma \operatorname{cov}\left(D_{i j}, C_{j}\right) / \sigma_{C i}}{\left(1+R_{j, t}\right)^{j-t}},
$$

where $R_{j t}$ is the risk-free rate for $j$ period loans at time $t ; \gamma$ is the constant price of risk; and $\sigma$ is the standard deviation of consumption in period $j$.

To implement the theory, each individual's consumption in period $j, C_{j}$ is taken to be proportional to the aggregate rate of return series, $R_{m t}$. This is justifiable only if capital holders have no other income sources and if a constant fraction of aggregate income is reinvested.

The rate-of-return models described above contain two models for the stochastic behavior of the market rate of return: first-order autoregres-

11. Douglas T. Breeden, "An Intertemporal Asset Pricing Model with Stochastic Consumption and Investment Opportunities," Journal of Financial Economics, vol. 7 (September 1979), pp. 265-96. 
sive and independently, identically distributed for each period. The first implies that the variance of the market rate grows as $\left(1-\delta^{2 t}\right) /\left(1-\delta^{2}\right)$, where $\delta$ is the market autoregressive coefficient, while the second implies that the variance remains constant.

If the firm's earnings are generated by model 4 , the covariance of the cash flow of firm $j$ in period $t+\tau$ and the market is $K_{j, t+\tau} \operatorname{cov}\left(R_{j, t+\tau}\right.$, $\left.R_{m, t+\tau}\right)$, which equals $K_{j, t+\tau} \beta_{j}\left(1+\delta^{2}+\ldots \delta^{2(\tau-1)}\right) \sigma^{2}\left(\epsilon_{m t}\right)$. Thus the riskadjusted present discounted value of firm $j$ in period $t, M V_{j, t}$ is given by

$$
M V_{j, t}=\sum_{\tau=0}^{\infty} \frac{E(\text { cash payout })_{t+\tau}}{\left(1+R_{f}\right)^{\tau}}-\theta \beta_{j} \sum_{\tau=0}^{\infty} \frac{K_{j, t+\tau}\left(\frac{1-\delta^{2 \tau}}{1-\delta^{2}}\right)^{1 / 2}}{\left(1+R_{f}\right)^{\tau}},
$$

where $R_{f}$ is the (assumed constant) risk-free discount rate and $\theta$ is the price of risk $\gamma$ multiplied by $\sigma\left(\varepsilon_{m t}\right)$. For each $t, \theta$ is taken to be constant; we assume agents do not expect changes in the price or quantity of risk. However, they may have different expectations at different times. The case in which the market is independent and identically distributed corresponds to $\delta=0$.

Dividing both sides of equation 4 by the expected value of future cash flows allows $Z$ for each firm to be calculated as a function of $R_{f}$ and $\theta$ :

$$
\begin{aligned}
Z_{j, t}\left(R_{f}, \theta\right) & \equiv \frac{M V_{j, t}}{\sum_{\tau=0}^{\infty} \frac{E(\text { cash payout })_{t+\tau}}{\left(1+R_{f}\right)^{\tau}}} \\
& =1-\theta \frac{\beta_{j} \sum_{\tau=0}^{\infty} \frac{K_{j, t+\tau}\left(\frac{1-\delta^{2 \tau}}{1-\delta^{2}}\right)^{1 / 2}}{\sum_{\tau=0}^{\infty} \frac{E(\text { cash payout })_{t+\tau}}{\left(1+R_{f}\right)^{\tau}}} .}{} .
\end{aligned}
$$

Assuming that the market value of a firm differs from intrinsic value by an error proportional to the expected value of future cash flows, the maximum likelihood estimates of $R_{f}$ and $\theta$ can be determined by finding the values that minimize $\sum_{j}\left(Z_{j, l}\left(R_{f}, \theta\right)-1\right)^{2}$. The value of $R_{f}$, which (together with $\theta$ ) minimizes this expression, is called the adjusted risk-free rate and is reported in table 9. For comparison, the unadjusted rate that made the aggregate $Z$ equal to 1 and the difference, termed the risk discount, are 
Table 9. Risk-Adjusted and Unadjusted Internal Rates of Return for Model 4, 1958-77 a Percent

\begin{tabular}{|c|c|c|c|c|c|c|}
\hline \multirow[b]{2}{*}{ Year } & \multicolumn{2}{|c|}{ Constant-capital case } & \multirow{2}{*}{$\begin{array}{c}\text { Risk } \\
\text { discount } \\
\text { (percentage } \\
\text { points) }\end{array}$} & \multicolumn{2}{|c|}{ Cash-out case } & \multirow{2}{*}{$\begin{array}{c}\text { Risk } \\
\text { discount } \\
\text { (percentage } \\
\text { points) }\end{array}$} \\
\hline & Unadjusted & Risk free & & Unadjusted & Risk free & \\
\hline 1958 & 3.9 & 1.9 & -2 & 2.9 & -0.1 & -3 \\
\hline 1959 & 4.6 & 2.6 & -2 & 3.2 & -0.8 & -4 \\
\hline 1960 & 4.8 & 3.8 & -1 & 3.8 & -0.8 & -3 \\
\hline 1961 & 3.9 & 2.9 & -1 & 2.0 & 0.0 & -2 \\
\hline 1962 & 5.4 & 4.4 & -1 & 4.4 & 3.4 & -1 \\
\hline 1963 & 5.0 & 4.0 & -1 & 3.4 & 2.4 & -1 \\
\hline 1964 & 4.7 & 4.7 & 0 & 2.6 & 0.6 & -2 \\
\hline 1965 & 4.9 & 3.9 & -1 & 2.8 & 0.8 & -2 \\
\hline 1966 & 6.1 & 5.1 & -1 & 5.2 & 3.2 & -2 \\
\hline 1967 & 4.3 & 3.3 & -1 & 2.8 & -0.8 & -2 \\
\hline 1968 & 4.6 & 3.6 & -1 & 3.2 & 1.2 & -2 \\
\hline 1969 & 5.2 & 3.2 & -2 & 4.9 & -0.9 & -4 \\
\hline 1970 & 4.8 & 3.8 & -1 & 5.0 & 2.0 & -3 \\
\hline 1971 & 4.3 & 2.3 & -2 & 4.4 & 1.4 & -3 \\
\hline 1972 & 4.1 & 2.1 & -2 & 3.7 & -0.3 & -4 \\
\hline 1973 & 8.2 & 5.2 & -3 & 8.9 & 2.9 & -6 \\
\hline 1974 & 15.2 & 10.2 & -5 & 18.6 & 11.6 & -7 \\
\hline 1975 & 8.8 & 6.8 & -2 & 12.0 & 8.0 & -4 \\
\hline 1976 & 7.3 & 6.3 & -1 & 9.9 & 8.9 & -1 \\
\hline 1977 & 9.3 & 8.3 & -1 & 12.9 & 11.9 & -1 \\
\hline
\end{tabular}

Source: Same as table 6.

a. For a description of model 4 , see table 8 , note a. The risk discount is the difference between the riskfree rate of return and the unadjusted one. See text derivation of both.

reported. ${ }^{12}$ If risk is an important factor affecting market value, the unadjusted rate commingles the risk and time discounting in an inappropriate way.

Variations in the risk discount seem to explain some of the variations in aggregate market values, and increases in the risk discount explain some of the decline in the market. The variations in the adjusted rates over time are less than those in the unadjusted rates. Nevertheless, there is still much cross-sectional variation in the $Z$ that cannot be explained by these time and risk discounts. The standard error of $[Z-1-\theta \times($ risk $)]$ for the constant-capital case is always greater than 0.29 (in 1977), reaching a maximum of 0.56 (in 1960).

12. The fact that the risk-discount results are always integers simply reflects the coarseness of our maximum likelihood search procedure. 


\section{Analysis of Cross-sectional Variation in Market Values}

In this section we examine a variety of hypotheses about the decline in the market value of capital by regressing the $Z$ of individual firms on a number of characteristics of those firms.

The variables fall into four groups. The first group contains two risk measures intended to examine the possibility that increasing risk is responsible for the decline in firms' valuation. The variables in the second group are included to examine the effects of inflation on firms' $Z$. These may arise because of the inflation confusions such as those suggested by Modigliani and Cohn, or because the market anticipates different inflation rates from those we embedded in our intrinsic value calculation. The third group of variables examines whether the market places more or less weight on distant earnings than our calculations, and whether there has been a change in the way they are weighted, reflecting a loss of confidence in the future earnings potential of firms. The fourth group contains variables that can influence valuation through factors not included in our procedure and can test the appropriateness of our assumptions.

Our discussion focuses on the results for two earnings projections: model 4, which assumes that firms' earnings depend on aggregate earnings and a firm-specific error, and model 7 , which uses a variety of variables (see table 3 ) to forecast the future rates of return. In these calculations the risk-unadjusted internal rates are used to calculate individual firms' $Z$, the effect of risk being freely estimated. Tables 10 and 11 show the results for model 4 under the cash-out and constant-capital assumptions, respectively, and table 12 shows the results for model 7 . In addition to reporting the year-by-year results, we also report estimates for the entire sample period and for the sample split in half. Table 13 gives the means and standard deviations of the variables used in the regressions.

EFFECTS OF DIVERSIFIABLE AND NONDIVERSIFIABLE RISK

Two measures of risk are included in the cross-sectional regressions, the measure of CAPM risk (RISK) developed above and a measure of the variation of a firm's rate of return that is independent of the aggregate $(O R I S K)$. This latter measure is proportional to the estimated standard deviation of the process generating the firm-specific error. In the case of 
Table 10. $Z$ Regressions, Model 4, Cash-Out Case, Aggregate Internal Rate Discounting, 1959-77

\begin{tabular}{|c|c|c|c|c|c|c|c|c|}
\hline \multirow{2}{*}{$\begin{array}{l}\text { Year and } \\
\text { period }\end{array}$} & \multirow[b]{2}{*}{ Mean Z } & \multirow[b]{2}{*}{ Constant } & \multirow[b]{2}{*}{$R I S K$} & \multirow[b]{2}{*}{ ORISK } & \multirow[b]{2}{*}{$F I V E$} & \multirow[b]{2}{*}{$P I N T$} & \multicolumn{2}{|c|}{ Independent } \\
\hline & & & & & & & $D I V$ & $C D I V$ \\
\hline 1959 & 0.9946 & $\begin{array}{l}-0.7502 \\
(-1.94)\end{array}$ & $\begin{array}{l}-2.3977 \\
(-0.81)\end{array}$ & $\begin{array}{l}-0.2282 \\
(-1.79)\end{array}$ & $\begin{array}{l}1.9694 \\
(3.14)\end{array}$ & $\begin{array}{l}0.7458 \\
(0.95)\end{array}$ & $\begin{array}{l}0.4834 \\
(1.19)\end{array}$ & $\begin{array}{l}0.0932 \\
(0.63)\end{array}$ \\
\hline 1960 & 1.0352 & $\begin{array}{l}-0.4972 \\
(-1.21)\end{array}$ & $\begin{array}{l}-3.4054 \\
(-1.38)\end{array}$ & $\begin{array}{l}-0.1335 \\
(-1.15)\end{array}$ & $\begin{array}{l}1.7132 \\
(2.62)\end{array}$ & $\begin{array}{l}0.1503 \\
(0.23)\end{array}$ & $\begin{array}{l}0.3719 \\
(0.91)\end{array}$ & $\begin{array}{l}-0.2081 \\
(-1.60)\end{array}$ \\
\hline 1961 & 1.0085 & $\begin{array}{l}-0.4100 \\
(-1.20)\end{array}$ & $\begin{array}{l}0.3483 \\
(0.18)\end{array}$ & $\begin{array}{l}-0.0606 \\
(-0.66)\end{array}$ & $\begin{array}{l}1.1325 \\
(2.33)\end{array}$ & $\begin{array}{l}-0.3368 \\
(-0.60)\end{array}$ & $\begin{array}{l}0.3893 \\
(1.19)\end{array}$ & $\begin{array}{l}0.2453 \\
(1.17)\end{array}$ \\
\hline 1962 & 0.9501 & $\begin{array}{l}-0.0842 \\
(-0.37)\end{array}$ & $\begin{array}{l}-0.7445 \\
(-0.49)\end{array}$ & $\begin{array}{l}-0.1844 \\
(-2.56)\end{array}$ & $\begin{array}{l}0.3117 \\
(0.80)\end{array}$ & $\begin{array}{l}-0.1435 \\
(-0.36)\end{array}$ & $\begin{array}{l}0.4604 \\
(1.97)\end{array}$ & $\begin{array}{l}0.1773 \\
(1.54)\end{array}$ \\
\hline 1963 & 0.9282 & $\begin{array}{l}-0.2653 \\
(-0.92)\end{array}$ & $\begin{array}{l}-0.1219 \\
(-0.07)\end{array}$ & $\begin{array}{l}-0.1315 \\
(-1.64)\end{array}$ & $\begin{array}{l}0.2423 \\
(0.56)\end{array}$ & $\begin{array}{c}0.0598 \\
(0.13)\end{array}$ & $\begin{array}{l}0.6401 \\
(2.17)\end{array}$ & $\begin{array}{l}0.1457 \\
(0.74)\end{array}$ \\
\hline 1964 & 0.9100 & $\begin{array}{l}-0.3182 \\
(-1.20)\end{array}$ & $\begin{array}{c}0.0239 \\
(0.02)\end{array}$ & $\begin{array}{l}-0.2272 \\
(-2.98)\end{array}$ & $\begin{array}{l}0.5989 \\
(1.61)\end{array}$ & $\begin{array}{l}0.0045 \\
(0.01)\end{array}$ & $\begin{array}{l}0.6485 \\
(2.17)\end{array}$ & $\begin{array}{l}-0.0296 \\
(-0.17)\end{array}$ \\
\hline 1965 & 0.9808 & $\begin{array}{l}-0.2157 \\
(-0.80)\end{array}$ & $\begin{array}{l}0.9072 \\
(0.52)\end{array}$ & $\begin{array}{l}-0.2674 \\
(-3.00)\end{array}$ & $\begin{array}{c}0.3660 \\
(0.91)\end{array}$ & $\begin{array}{l}0.3400 \\
(0.78)\end{array}$ & $\begin{array}{l}0.2372 \\
(0.76)\end{array}$ & $\begin{array}{l}0.0796 \\
(0.65)\end{array}$ \\
\hline 1966 & 0.9724 & $\begin{array}{l}-0.2641 \\
(-0.79)\end{array}$ & $\begin{array}{l}-0.0069 \\
(-0.00)\end{array}$ & $\begin{array}{l}-0.2965 \\
(-2.59)\end{array}$ & $\begin{array}{l}-0.6981 \\
(-1.24)\end{array}$ & $\begin{array}{l}0.2170 \\
(0.43)\end{array}$ & $\begin{array}{l}0.4280 \\
(1.13)\end{array}$ & $\begin{array}{l}0.1702 \\
(0.72)\end{array}$ \\
\hline 1967 & 0.9987 & $\begin{array}{l}-0.7302 \\
(-2.25)\end{array}$ & $\begin{array}{l}0.9666 \\
(0.50)\end{array}$ & $\begin{array}{l}-0.0200 \\
(-0.20)\end{array}$ & $\begin{array}{l}0.0283 \\
(0.05)\end{array}$ & $\begin{array}{l}0.3498 \\
(0.67)\end{array}$ & $\begin{array}{l}-0.2246 \\
(-0.57)\end{array}$ & $\begin{array}{l}-0.0760 \\
(-0.33)\end{array}$ \\
\hline 1968 & 1.0447 & $\begin{array}{l}-0.5209 \\
(-1.86)\end{array}$ & $\begin{array}{l}-2.4601 \\
(-1.46)\end{array}$ & $\begin{array}{l}0.0130 \\
(0.16)\end{array}$ & $\begin{array}{l}0.0798 \\
(0.16)\end{array}$ & $\begin{array}{l}0.1731 \\
(0.45)\end{array}$ & $\begin{array}{l}0.0448 \\
(0.13)\end{array}$ & $\begin{array}{l}0.1721 \\
(0.81)\end{array}$ \\
\hline 1969 & 1.0139 & $\begin{array}{l}-0.1790 \\
(-0.47)\end{array}$ & $\begin{array}{l}-5.1359 \\
(-2.47)\end{array}$ & $\begin{array}{l}-0.1296 \\
(-1.27)\end{array}$ & $\begin{array}{l}-2.3357 \\
(-3.22)\end{array}$ & $\begin{array}{l}0.3083 \\
(0.70)\end{array}$ & $\begin{array}{l}0.0336 \\
(0.08)\end{array}$ & $\begin{array}{l}0.0322 \\
(0.13)\end{array}$ \\
\hline 1970 & 0.9767 & $\begin{array}{l}-0.3424 \\
(-1.02)\end{array}$ & $\begin{array}{l}-5.1892 \\
(-2.55)\end{array}$ & $\begin{array}{l}0.0759 \\
(0.97)\end{array}$ & $\begin{array}{l}-0.8533 \\
(-1.30)\end{array}$ & $\begin{array}{l}0.2199 \\
(0.62)\end{array}$ & $\begin{array}{l}0.6796 \\
(1.82)\end{array}$ & $\begin{array}{l}0.1569 \\
(1.02)\end{array}$ \\
\hline 1971 & 1.0304 & $\begin{array}{l}0.1563 \\
(0.44)\end{array}$ & $\begin{array}{l}-1.8109 \\
(-0.99)\end{array}$ & $\begin{array}{l}0.0838 \\
(1.16)\end{array}$ & $\begin{array}{l}-0.9170 \\
(-1.45)\end{array}$ & $\begin{array}{l}-0.2399 \\
(-1.56)\end{array}$ & $\begin{array}{l}-0.4375 \\
(-1.12)\end{array}$ & $\begin{array}{l}0.0609 \\
(0.42)\end{array}$ \\
\hline 1972 & 0.9780 & $\begin{array}{l}-0.0973 \\
(-0.23)\end{array}$ & $\begin{array}{l}-3.2802 \\
(-1.58)\end{array}$ & $\begin{array}{l}0.0032 \\
(0.03)\end{array}$ & $\begin{array}{l}-1.5204 \\
(-1.99)\end{array}$ & $\begin{array}{l}-0.2998 \\
(-0.55)\end{array}$ & $\begin{array}{l}-0.6680 \\
(-1.31)\end{array}$ & $\begin{array}{l}0.0601 \\
(0.35)\end{array}$ \\
\hline 1973 & 0.9543 & $\begin{array}{l}1.1603 \\
(1.79)\end{array}$ & $\begin{array}{l}-9.6494 \\
(-3.19)\end{array}$ & $\begin{array}{l}-0.3039 \\
(-1.82)\end{array}$ & $\begin{array}{l}-2.1226 \\
(-1.58)\end{array}$ & $\begin{array}{l}-0.6949 \\
(-1.00)\end{array}$ & $\begin{array}{l}-0.3416 \\
(-0.44)\end{array}$ & $\begin{array}{l}0.1307 \\
(0.72)\end{array}$ \\
\hline 1974 & 1.0118 & $\begin{array}{l}2.2169 \\
(2.34)\end{array}$ & $\begin{array}{l}-14.0277 \\
(-3.64)\end{array}$ & $\begin{array}{l}-0.6527 \\
(-4.19)\end{array}$ & $\begin{array}{l}-2.6692 \\
(-1.62)\end{array}$ & $\begin{array}{l}0.1945 \\
(0.54)\end{array}$ & $\begin{array}{l}1.2370 \\
(2.34)\end{array}$ & $\begin{array}{l}0.7122 \\
(2.80)\end{array}$ \\
\hline 1975 & 0.9809 & $\begin{array}{l}0.8340 \\
(1.56)\end{array}$ & $\begin{array}{l}-3.0563 \\
(-1.19)\end{array}$ & $\begin{array}{l}-0.2306 \\
(-2.16)\end{array}$ & $\begin{array}{l}-1.3505 \\
(-1.29)\end{array}$ & $\begin{array}{l}0.1782 \\
(0.46)\end{array}$ & $\begin{array}{l}1.4477 \\
(3.19)\end{array}$ & $\begin{array}{l}-0.0915 \\
(-0.62)\end{array}$ \\
\hline 1976 & 0.9277 & $\begin{array}{l}0.4256 \\
(1.26)\end{array}$ & $\begin{array}{l}-5.9851 \\
(-3.73)\end{array}$ & $\begin{array}{l}-0.0820 \\
(-1.19)\end{array}$ & $\begin{array}{l}-0.5582 \\
(-0.85)\end{array}$ & $\begin{array}{l}0.2286 \\
(0.71)\end{array}$ & $\begin{array}{l}1.4519 \\
(3.60)\end{array}$ & $\begin{array}{l}-0.0994 \\
(-0.83)\end{array}$ \\
\hline 1977 & 0.9486 & $\begin{array}{l}0.8956 \\
(2.94)\end{array}$ & $\begin{array}{l}-7.8127 \\
(-6.60)\end{array}$ & $\begin{array}{l}-0.1979 \\
(-3.29)\end{array}$ & $\begin{array}{l}-0.8583 \\
(-1.51)\end{array}$ & $\begin{array}{l}0.7070 \\
(2.65)\end{array}$ & $\begin{array}{l}1.2656 \\
(4.41)\end{array}$ & $\begin{array}{l}-0.0787 \\
(-0.63)\end{array}$ \\
\hline $1959-77$ & 0.9813 & $\ldots$ & $\begin{array}{l}-1.9218 \\
(-4.43)\end{array}$ & $\begin{array}{l}-0.0649 \\
(-3.04)\end{array}$ & $\begin{array}{l}0.5059 \\
(3.77)\end{array}$ & $\begin{array}{l}0.0867 \\
(0.87)\end{array}$ & $\begin{array}{l}0.4775 \\
(5.60)\end{array}$ & $\begin{array}{l}0.0223 \\
(0.62)\end{array}$ \\
\hline $1959-67$ & 0.9754 & $\cdots$ & $\begin{array}{c}0.0709 \\
(0.11)\end{array}$ & $\begin{array}{l}-0.1385 \\
(-4.47)\end{array}$ & $\begin{array}{l}0.8018 \\
(4.91)\end{array}$ & $\begin{array}{l}0.0971 \\
(0.57)\end{array}$ & $\begin{array}{l}0.4387 \\
(4.04)\end{array}$ & $\begin{array}{l}0.0203 \\
(0.42)\end{array}$ \\
\hline $1968-77$ & 0.9867 & $\cdots$ & $\begin{array}{l}-3.8425 \\
(-6.17)\end{array}$ & $\begin{array}{l}-0.0542 \\
(-1.82)\end{array}$ & $\begin{array}{l}-0.7377 \\
(-3.06)\end{array}$ & $\begin{array}{l}0.2034 \\
(1.60)\end{array}$ & $\begin{array}{l}0.4702 \\
(3.47)\end{array}$ & $\begin{array}{l}-0.0133 \\
(-0.26)\end{array}$ \\
\hline
\end{tabular}

Source: Estimations by the authors. The aggregate internal rate used in the discounting is from the column for model 4 in table 7 . For a description of this model see table 8 , note a.

a. The $O R I S K$ and $R I S K$ variables represent the firm's own risk as measured by the standard error of the equation relating firms' rate of return to the aggregate rate of return and a measure of risk based on the capital-asset pricing model, respectively; FIVE is defined as

$$
\sum_{\tau=1}^{5} \frac{G C F_{\tau}}{\left(1+R_{f}\right)^{\tau}} / \sum_{\tau=1}^{\infty} \frac{G C F_{\tau}}{\left(1+R_{f}\right)^{\tau}}
$$




\begin{tabular}{|c|c|c|c|c|c|c|c|c|}
\hline \multicolumn{8}{|l|}{ variable } & \multirow[b]{2}{*}{$R^{2}$} \\
\hline CSALES & $R D E P$ & $G R A T E$ & $C G R A T E$ & $R I N V$ & $B L O A T 1$ & $B L O A T 2$ & $B L O A T 3$ & \\
\hline $\begin{array}{l}0.4456 \\
(0.99)\end{array}$ & $\begin{array}{l}-0.2579 \\
(-0.37)\end{array}$ & $\begin{array}{l}2.7644 \\
(3.89)\end{array}$ & $\begin{array}{l}1.5748 \\
(1.61)\end{array}$ & $\begin{array}{l}2.8581 \\
(2.31)\end{array}$ & $\begin{array}{l}-1.5285 \\
(-0.22)\end{array}$ & $\begin{array}{l}2.1584 \\
(1.47)\end{array}$ & $\begin{array}{l}0.4218 \\
(0.80)\end{array}$ & 0.42 \\
\hline $\begin{array}{l}0.4365 \\
(1.15)\end{array}$ & $\begin{array}{l}-0.6384 \\
(-1.10)\end{array}$ & $\begin{array}{l}3.3148 \\
(4.16)\end{array}$ & $\begin{array}{l}-2.8823 \\
(-2.33)\end{array}$ & $\begin{array}{l}3.5785 \\
(3.85)\end{array}$ & $\begin{array}{l}-0.9616 \\
(-0.18)\end{array}$ & $\begin{array}{l}2.2242 \\
(1.72)\end{array}$ & $\begin{array}{l}1.0653 \\
(2.02)\end{array}$ & 0.47 \\
\hline $\begin{array}{l}0.2813 \\
(0.72)\end{array}$ & $\begin{array}{l}0.2269 \\
(0.47)\end{array}$ & $\begin{array}{l}4.2118 \\
(5.61)\end{array}$ & $\begin{array}{l}-1.5114 \\
(-1.37)\end{array}$ & $\begin{array}{l}1.8891 \\
(2.06)\end{array}$ & $\begin{array}{l}-0.3312 \\
(-0.02)\end{array}$ & $\begin{array}{l}0.2971 \\
(0.26)\end{array}$ & $\begin{array}{l}0.9053 \\
(2.16)\end{array}$ & 0.56 \\
\hline $\begin{array}{l}0.1655 \\
(0.56)\end{array}$ & $\begin{array}{l}0.3708 \\
(1.06)\end{array}$ & $\begin{array}{c}3.7738 \\
(7.14)\end{array}$ & $\begin{array}{l}-1.7834 \\
(-1.93)\end{array}$ & $\begin{array}{l}1.0125 \\
(1.71)\end{array}$ & $\begin{array}{l}-0.6958 \\
(-0.12)\end{array}$ & $\begin{array}{l}0.7676 \\
(0.79)\end{array}$ & $\begin{array}{l}0.8307 \\
(2.71)\end{array}$ & 0.61 \\
\hline $\begin{array}{l}0.4515 \\
(1.60)\end{array}$ & $\begin{array}{l}0.6714 \\
(1.63)\end{array}$ & $\begin{array}{l}3.8280 \\
(5.99)\end{array}$ & $\begin{array}{l}-2.4053 \\
(-2.19)\end{array}$ & $\begin{array}{l}0.8409 \\
(1.24)\end{array}$ & $\begin{array}{l}-2.3209 \\
(-0.70)\end{array}$ & $\begin{array}{c}0.4301 \\
(0.39)\end{array}$ & $\begin{array}{l}0.9411 \\
(2.62)\end{array}$ & 0.56 \\
\hline $\begin{array}{l}0.3668 \\
(1.93)\end{array}$ & $\begin{array}{l}0.6300 \\
(1.56)\end{array}$ & $\begin{array}{l}3.6399 \\
(6.58)\end{array}$ & $\begin{array}{l}-2.7013 \\
(-2.63)\end{array}$ & $\begin{array}{l}0.6927 \\
(1.12)\end{array}$ & $\begin{array}{l}0.2979 \\
(0.13)\end{array}$ & $\begin{array}{l}0.6238 \\
(0.52)\end{array}$ & $\begin{array}{l}0.5779 \\
(1.67)\end{array}$ & 0.58 \\
\hline $\begin{array}{l}0.2290 \\
(0.83)\end{array}$ & $\begin{array}{l}0.1959 \\
(0.45)\end{array}$ & $\begin{array}{l}4.0819 \\
(7.20)\end{array}$ & $\begin{array}{l}-1.0917 \\
(-0.99)\end{array}$ & $\begin{array}{l}2.3689 \\
(4.05)\end{array}$ & $\begin{array}{l}0.4602 \\
(0.49)\end{array}$ & $\begin{array}{l}1.1325 \\
(0.74)\end{array}$ & $\begin{array}{l}1.2066 \\
(3.04)\end{array}$ & 0.65 \\
\hline $\begin{array}{l}0.5409 \\
(1.41)\end{array}$ & $\begin{array}{l}1.2801 \\
(2.47)\end{array}$ & $\begin{array}{l}5.0359 \\
(6.88)\end{array}$ & $\begin{array}{l}-2.6621 \\
(-1.93)\end{array}$ & $\begin{array}{l}1.2372 \\
(2.10)\end{array}$ & $\begin{array}{l}0.9049 \\
(0.73)\end{array}$ & $\begin{array}{l}-0.3219 \\
(-0.16)\end{array}$ & $\begin{array}{l}0.4315 \\
(0.95)\end{array}$ & 0.55 \\
\hline $\begin{array}{l}0.6935 \\
(2.21)\end{array}$ & $\begin{array}{l}1.2340 \\
(2.33)\end{array}$ & $\begin{array}{l}6.3263 \\
(7.37)\end{array}$ & $\begin{array}{l}-3.6337 \\
(-2.54)\end{array}$ & $\begin{array}{l}0.4339 \\
(0.58)\end{array}$ & $\begin{array}{l}1.2738 \\
(1.05)\end{array}$ & $\begin{array}{l}1.6973 \\
(0.76)\end{array}$ & $\begin{array}{l}0.5733 \\
(1.27)\end{array}$ & 0.55 \\
\hline $\begin{array}{l}0.6778 \\
(2.43)\end{array}$ & $\begin{array}{l}0.9619 \\
(2.11)\end{array}$ & $\begin{array}{l}5.5973 \\
(8.73)\end{array}$ & $\begin{array}{l}-2.0523 \\
(-1.96)\end{array}$ & $\begin{array}{l}0.5453 \\
(0.85)\end{array}$ & $\begin{array}{l}0.9750 \\
(1.05)\end{array}$ & $\begin{array}{l}1.2415 \\
(0.65)\end{array}$ & $\begin{array}{l}0.7762 \\
(1.94)\end{array}$ & 0.58 \\
\hline $\begin{array}{l}0.8043 \\
(1.98)\end{array}$ & $\begin{array}{l}1.5490 \\
(2.29)\end{array}$ & $\begin{array}{l}8.1085 \\
(8.95)\end{array}$ & $\begin{array}{l}-5.1073 \\
(-2.89)\end{array}$ & $\begin{array}{l}1.9139 \\
(2.00)\end{array}$ & $\begin{array}{l}0.1437 \\
(0.20)\end{array}$ & $\begin{array}{l}0.7984 \\
(0.30)\end{array}$ & $\begin{array}{l}0.9775 \\
(1.82)\end{array}$ & 0.57 \\
\hline $\begin{array}{l}0.7863 \\
(2.48)\end{array}$ & $\begin{array}{l}0.7502 \\
(1.21)\end{array}$ & $\begin{array}{l}5.9970 \\
(6.73)\end{array}$ & $\begin{array}{l}-1.9626 \\
(-1.37)\end{array}$ & $\begin{array}{l}1.4451 \\
(1.43)\end{array}$ & $\begin{array}{l}0.3422 \\
(0.41)\end{array}$ & $\begin{array}{l}1.1786 \\
(0.53)\end{array}$ & $\begin{array}{l}0.5530 \\
(1.22)\end{array}$ & 0.53 \\
\hline $\begin{array}{l}-0.2068 \\
(-0.53)\end{array}$ & $\begin{array}{l}0.2942 \\
(0.45)\end{array}$ & $\begin{array}{l}7.3933 \\
(7.99)\end{array}$ & $\begin{array}{l}-2.9006 \\
(-1.95)\end{array}$ & $\begin{array}{l}1.8224 \\
(1.84)\end{array}$ & $\begin{array}{l}-1.0001 \\
(-1.21)\end{array}$ & $\begin{array}{l}1.0539 \\
(0.48)\end{array}$ & $\begin{array}{l}1.0783 \\
(2.15)\end{array}$ & 0.59 \\
\hline $\begin{array}{l}0.0703 \\
(0.14)\end{array}$ & $\begin{array}{l}0.7628 \\
(0.95)\end{array}$ & $\begin{array}{l}8.1374 \\
(7.53)\end{array}$ & $\begin{array}{l}1.1911 \\
(0.55)\end{array}$ & $\begin{array}{l}3.9128 \\
(3.10)\end{array}$ & $\begin{array}{l}-0.5194 \\
(-0.57)\end{array}$ & $\begin{array}{l}0.9571 \\
(0.37)\end{array}$ & $\begin{array}{l}1.2877 \\
(1.97)\end{array}$ & 0.58 \\
\hline $\begin{array}{l}1.1673 \\
(2.04)\end{array}$ & $\begin{array}{l}0.2698 \\
(0.22)\end{array}$ & $\begin{array}{l}5.0893 \\
(3.55)\end{array}$ & $\begin{array}{l}-6.1487 \\
(-2.50)\end{array}$ & $\begin{array}{l}4.1609 \\
(2.70)\end{array}$ & $\begin{array}{l}-0.7121 \\
(-1.13)\end{array}$ & $\begin{array}{l}0.3636 \\
(0.10)\end{array}$ & $\begin{array}{l}1.2755 \\
(1.30)\end{array}$ & 0.47 \\
\hline $\begin{array}{l}-0.0442 \\
(-0.15)\end{array}$ & $\begin{array}{l}-0.4887 \\
(-0.48)\end{array}$ & $\begin{array}{l}2.0063 \\
(1.88)\end{array}$ & $\begin{array}{l}-4.6528 \\
(-3.74)\end{array}$ & $\begin{array}{l}5.0096 \\
(4.87)\end{array}$ & $\begin{array}{l}0.1526 \\
(0.40)\end{array}$ & $\begin{array}{l}-0.2252 \\
(-0.07)\end{array}$ & $\begin{array}{l}2.8177 \\
(2.92)\end{array}$ & 0.47 \\
\hline $\begin{array}{l}0.3234 \\
(1.00)\end{array}$ & $\begin{array}{c}1.3808 \\
(1.86)\end{array}$ & $\begin{array}{l}3.1108 \\
(2.63)\end{array}$ & $\begin{array}{l}-3.6820 \\
(-3.27)\end{array}$ & $\begin{array}{l}2.3267 \\
(2.37)\end{array}$ & $\begin{array}{l}-0.7337 \\
(-0.93)\end{array}$ & $\begin{array}{l}-3.5551 \\
(-1.88)\end{array}$ & $\begin{array}{l}1.8568 \\
(2.40)\end{array}$ & 0.43 \\
\hline $\begin{array}{l}0.1217 \\
(0.53)\end{array}$ & $\begin{array}{l}0.8372 \\
(1.59)\end{array}$ & $\begin{array}{l}2.5787 \\
(3.01)\end{array}$ & $\begin{array}{l}1.5634 \\
(1.25)\end{array}$ & $\begin{array}{l}2.2638 \\
(3.13)\end{array}$ & $\begin{array}{l}-0.5212 \\
(-1.16)\end{array}$ & $\begin{array}{l}-2.0981 \\
(-1.65)\end{array}$ & $\begin{array}{l}1.1511 \\
(2.25)\end{array}$ & 0.49 \\
\hline $\begin{array}{l}0.7717 \\
(2.74)\end{array}$ & $\begin{array}{l}0.1054 \\
(0.26)\end{array}$ & $\begin{array}{l}1.9083 \\
(2.96)\end{array}$ & $\begin{array}{l}-0.4490 \\
(-0.39)\end{array}$ & $\begin{array}{l}1.9499 \\
(3.09)\end{array}$ & $\begin{array}{l}-0.6802 \\
(-1.92)\end{array}$ & $\begin{array}{l}-0.6594 \\
(-0.69)\end{array}$ & $\begin{array}{l}1.0933 \\
(2.87)\end{array}$ & 0.53 \\
\hline $\begin{array}{l}0.3384 \\
(4.52)\end{array}$ & $\begin{array}{l}0.1164 \\
(0.97)\end{array}$ & $\begin{array}{l}3.9122 \\
(23.32)\end{array}$ & $\begin{array}{l}-1.8501 \\
(-7.03)\end{array}$ & $\begin{array}{l}2.2000 \\
(11.68)\end{array}$ & $\begin{array}{l}-0.1563 \\
(-1.05)\end{array}$ & $\begin{array}{l}0.5398 \\
(1.76)\end{array}$ & $\begin{array}{l}0.9983 \\
(9.27)\end{array}$ & 0.44 \\
\hline $\begin{array}{l}0.3276 \\
(3.19)\end{array}$ & $\begin{array}{l}0.3359 \\
(2.15)\end{array}$ & $\begin{array}{l}3.8343 \\
(17.83)\end{array}$ & $\begin{array}{l}-1.3772 \\
(-4.07)\end{array}$ & $\begin{array}{l}1.8495 \\
(7.68)\end{array}$ & $\begin{array}{l}0.9286 \\
(1.60)\end{array}$ & $\begin{array}{l}0.8374 \\
(2.12)\end{array}$ & $\begin{array}{l}0.7696 \\
(5.66)\end{array}$ & 0.49 \\
\hline $\begin{array}{l}0.3929 \\
(3.68)\end{array}$ & $\begin{array}{l}0.3255 \\
(1.68)\end{array}$ & $\begin{array}{c}5.0848 \\
(18.01)\end{array}$ & $\begin{array}{l}-2.7592 \\
(-6.77)\end{array}$ & $\begin{array}{l}2.4439 \\
(8.31)\end{array}$ & $\begin{array}{l}-0.3369 \\
(-2.03)\end{array}$ & $\begin{array}{l}0.2540 \\
(0.50)\end{array}$ & $\begin{array}{l}1.2534 \\
(6.89)\end{array}$ & 0.43 \\
\hline
\end{tabular}

and represents the discounted earnings in the near future as a proportion of distant earnings; PINT, DIV, and $R D E P$ are the ratio to gross after-tax cash flows of interest, dividends, and real depreciation charges, respectively; CSALES is the change in sales; GRATE and CGRATE are the gross rate of return and the change in gross rate of return, respectively; $R I N V$ is the ratio of gross investment to net capital stock; BLOAT1, BLOAT2, and BLOAT3 are the ratio to gross after-tax cash flows of inventory profits, the difference between real and book depreciation, and the difference between the estimated value of book depreciation and what firms actually report, respectively. The numbers in parentheses are $t$-statistics. 
Table 11. $Z$ Regressions, Model 4, Constant-Capital Case, Aggregate Internal Rate Discounting, 1959-77

\begin{tabular}{|c|c|c|c|c|c|c|c|c|}
\hline \multirow{2}{*}{$\begin{array}{l}\text { Year and } \\
\text { period }\end{array}$} & \multirow[b]{2}{*}{ Mean Z } & \multirow[b]{2}{*}{ Constant } & \multirow[b]{2}{*}{$R I S K$} & \multirow[b]{2}{*}{ ORISK } & \multirow[b]{2}{*}{$F I V E$} & \multirow[b]{2}{*}{ PINT } & \multicolumn{2}{|c|}{ Independent } \\
\hline & & & & & & & $D I V$ & $C D I V$ \\
\hline 1959 & 0.9889 & $\begin{array}{l}-0.0115 \\
(-0.03)\end{array}$ & $\begin{array}{l}-0.8226 \\
(-1.64)\end{array}$ & $\begin{array}{l}0.0294 \\
(0.85)\end{array}$ & $\begin{array}{l}-2.7081 \\
(-3.12)\end{array}$ & $\begin{array}{l}0.7769 \\
(0.93)\end{array}$ & $\begin{array}{l}0.0858 \\
(0.20)\end{array}$ & $\begin{array}{l}-0.0204 \\
(-0.13)\end{array}$ \\
\hline 1960 & 1.0023 & $\begin{array}{l}0.0601 \\
(0.14)\end{array}$ & $\begin{array}{l}-0.2670 \\
(-0.47)\end{array}$ & $\begin{array}{l}-0.0007 \\
(-0.03)\end{array}$ & $\begin{array}{l}-0.7225 \\
(-1.00)\end{array}$ & $\begin{array}{l}-0.3050 \\
(-0.51)\end{array}$ & $\begin{array}{l}0.1629 \\
(0.41)\end{array}$ & $\begin{array}{l}0.0162 \\
(0.13)\end{array}$ \\
\hline 1961 & 0.9684 & $\begin{array}{l}0.2633 \\
(0.70)\end{array}$ & $\begin{array}{l}-0.3612 \\
(-0.91)\end{array}$ & $\begin{array}{l}0.0151 \\
(0.70)\end{array}$ & $\begin{array}{l}-1.1349 \\
(-1.75)\end{array}$ & $\begin{array}{l}-0.5122 \\
(-0.93)\end{array}$ & $\begin{array}{l}0.1411 \\
(0.41)\end{array}$ & $\begin{array}{l}0.4679 \\
(2.26)\end{array}$ \\
\hline 1962 & 0.9517 & $\begin{array}{l}-0.3484 \\
(-1.24)\end{array}$ & $\begin{array}{l}0.3923 \\
(1.01)\end{array}$ & $\begin{array}{l}-0.0537 \\
(-2.01)\end{array}$ & $\begin{array}{l}0.5468 \\
(1.21)\end{array}$ & $\begin{array}{l}-0.1537 \\
(-0.35)\end{array}$ & $\begin{array}{l}0.2198 \\
(0.73)\end{array}$ & $\begin{array}{l}0.1978 \\
(1.55)\end{array}$ \\
\hline 1963 & 0.9535 & $\begin{array}{l}-0.3661 \\
(-0.93)\end{array}$ & $\begin{array}{l}1.9272 \\
(5.14)\end{array}$ & $\begin{array}{l}-0.0101 \\
(-0.36)\end{array}$ & $\begin{array}{l}0.4592 \\
(0.67)\end{array}$ & $\begin{array}{l}-0.1057 \\
(-0.19)\end{array}$ & $\begin{array}{l}0.9752 \\
(2.50)\end{array}$ & $\begin{array}{l}0.2393 \\
(1.00)\end{array}$ \\
\hline 1964 & 0.9135 & $\begin{array}{l}0.2025 \\
(0.59)\end{array}$ & $\begin{array}{l}1.2056 \\
(3.19)\end{array}$ & $\begin{array}{l}-0.0527 \\
(-2.06)\end{array}$ & $\begin{array}{l}-0.7980 \\
(-1.24)\end{array}$ & $\begin{array}{l}0.2781 \\
(0.57)\end{array}$ & $\begin{array}{l}0.3436 \\
(1.03)\end{array}$ & $\begin{array}{l}0.0527 \\
(0.26)\end{array}$ \\
\hline 1965 & 0.9925 & $\begin{array}{l}0.2319 \\
(0.71)\end{array}$ & $\begin{array}{l}2.0892 \\
(4.48)\end{array}$ & $\begin{array}{l}-0.0495 \\
(-1.59)\end{array}$ & $\begin{array}{l}-0.7049 \\
(-1.00)\end{array}$ & $\begin{array}{l}0.4769 \\
(1.05)\end{array}$ & $\begin{array}{l}0.1679 \\
(0.50)\end{array}$ & $\begin{array}{l}0.1786 \\
(1.44)\end{array}$ \\
\hline 1966 & 0.9770 & $\begin{array}{l}-0.5121 \\
(-1.28)\end{array}$ & $\begin{array}{l}1.5517 \\
(2.62)\end{array}$ & $\begin{array}{l}-0.0868 \\
(-1.93)\end{array}$ & $\begin{array}{l}0.5207 \\
(0.62)\end{array}$ & $\begin{array}{l}0.3558 \\
(0.72)\end{array}$ & $\begin{array}{l}0.4176 \\
(1.07)\end{array}$ & $\begin{array}{l}0.0657 \\
(0.28)\end{array}$ \\
\hline 1967 & 0.9853 & $\begin{array}{l}-0.2790 \\
(-0.75)\end{array}$ & $\begin{array}{l}1.2539 \\
(2.80)\end{array}$ & $\begin{array}{l}0.0333 \\
(1.53)\end{array}$ & $\begin{array}{l}0.3289 \\
(0.40)\end{array}$ & $\begin{array}{l}0.1104 \\
(0.21)\end{array}$ & $\begin{array}{l}-0.3110 \\
(-0.79)\end{array}$ & $\begin{array}{c}0.2128 \\
(0.88)\end{array}$ \\
\hline 1968 & 1.0422 & $\begin{array}{l}0.3050 \\
(0.10)\end{array}$ & $\begin{array}{l}0.7455 \\
(1.78)\end{array}$ & $\begin{array}{l}0.0212 \\
(0.80)\end{array}$ & $\begin{array}{l}-0.0746 \\
(-0.11)\end{array}$ & $\begin{array}{l}-0.0283 \\
(-0.07)\end{array}$ & $\begin{array}{l}-0.1121 \\
(-0.30)\end{array}$ & $\begin{array}{l}0.1928 \\
(0.82)\end{array}$ \\
\hline 1969 & 0.9757 & $\begin{array}{l}-0.0133 \\
(-0.03)\end{array}$ & $\begin{array}{l}-0.8030 \\
(-1.60)\end{array}$ & $\begin{array}{l}-0.0248 \\
(-0.75)\end{array}$ & $\begin{array}{l}-0.7572 \\
(-1.05)\end{array}$ & $\begin{array}{l}0.3259 \\
(0.73)\end{array}$ & $\begin{array}{l}-0.0995 \\
(-0.24)\end{array}$ & $\begin{array}{l}-0.1008 \\
(-0.40)\end{array}$ \\
\hline 1970 & 0.9476 & $\begin{array}{l}-0.1534 \\
(-0.50)\end{array}$ & $\begin{array}{l}-0.4323 \\
(-1.09)\end{array}$ & $\begin{array}{l}0.0302 \\
(1.76)\end{array}$ & $\begin{array}{l}1.1098 \\
(2.21)\end{array}$ & $\begin{array}{l}-0.1035 \\
(-0.32)\end{array}$ & $\begin{array}{l}0.2927 \\
(0.82)\end{array}$ & $\begin{array}{l}0.2468 \\
(1.74)\end{array}$ \\
\hline 1971 & 0.9968 & $\begin{array}{l}0.4598 \\
(1.28)\end{array}$ & $\begin{array}{l}-0.0047 \\
(-0.01)\end{array}$ & $\begin{array}{l}0.0256 \\
(1.65)\end{array}$ & $\begin{array}{l}0.5962 \\
(1.22)\end{array}$ & $\begin{array}{l}-0.6753 \\
(-1.56)\end{array}$ & $\begin{array}{l}-0.4904 \\
(-1.27)\end{array}$ & $\begin{array}{l}-1.0247 \\
(-0.18)\end{array}$ \\
\hline 1972 & 0.9492 & $\begin{array}{l}0.2436 \\
(0.58)\end{array}$ & $\begin{array}{l}-0.6669 \\
(-1.63)\end{array}$ & $\begin{array}{l}0.0432 \\
(2.23)\end{array}$ & $\begin{array}{l}0.2682 \\
(0.43)\end{array}$ & $\begin{array}{l}-0.5154 \\
(-0.94)\end{array}$ & $\begin{array}{l}-0.2401 \\
(-0.47)\end{array}$ & $\begin{array}{l}0.0453 \\
(0.27)\end{array}$ \\
\hline 1973 & 0.9339 & $\begin{array}{l}0.5788 \\
(1.01)\end{array}$ & $\begin{array}{l}-3.0526 \\
(-3.52)\end{array}$ & $\begin{array}{l}-0.0783 \\
(-1.15)\end{array}$ & $\begin{array}{l}0.4955 \\
(0.61)\end{array}$ & $\begin{array}{l}-0.7791 \\
(-1.17)\end{array}$ & $\begin{array}{l}-0.4177 \\
(-0.55)\end{array}$ & $\begin{array}{c}0.0749 \\
(0.41)\end{array}$ \\
\hline 1974 & 1.0000 & $\begin{array}{l}1.0083 \\
(1.84)\end{array}$ & $\begin{array}{l}-5.6260 \\
(-4.18)\end{array}$ & $\begin{array}{l}-0.2448 \\
(-3.14)\end{array}$ & $\begin{array}{l}-1.2045 \\
(-1.42)\end{array}$ & $\begin{array}{l}0.1598 \\
(0.45)\end{array}$ & $\begin{array}{l}1.0036 \\
(1.92)\end{array}$ & $\begin{array}{l}0.3141 \\
(1.11)\end{array}$ \\
\hline 1975 & 0.9912 & $\begin{array}{l}-0.9959 \\
(-2.88)\end{array}$ & $\begin{array}{l}-0.6010 \\
(-0.96)\end{array}$ & $\begin{array}{l}0.0454 \\
(1.85)\end{array}$ & $\begin{array}{l}1.7515 \\
(3.88)\end{array}$ & $\begin{array}{l}-0.1644 \\
(-0.44)\end{array}$ & $\begin{array}{l}1.1033 \\
(2.39)\end{array}$ & $\begin{array}{l}-0.2654 \\
(-1.88)\end{array}$ \\
\hline 1976 & 0.9166 & $\begin{array}{l}-0.7192 \\
(-2.80)\end{array}$ & $\begin{array}{l}-0.6394 \\
(-1.93)\end{array}$ & $\begin{array}{l}0.0127 \\
(0.71)\end{array}$ & $\begin{array}{l}1.7403 \\
(5.20)\end{array}$ & $\begin{array}{l}-0.1342 \\
(-0.44)\end{array}$ & $\begin{array}{l}0.8792 \\
(2.15)\end{array}$ & $\begin{array}{l}-0.0388 \\
(-0.34)\end{array}$ \\
\hline 1977 & 0.9613 & $\begin{array}{l}-0.1410 \\
(-0.50)\end{array}$ & $\begin{array}{l}-1.2092 \\
(-3.31)\end{array}$ & $\begin{array}{c}0.1450 \\
(14.02)\end{array}$ & $\begin{array}{l}0.9818 \\
(2.26)\end{array}$ & $\begin{array}{l}0.0279 \\
(0.09)\end{array}$ & $\begin{array}{c}0.5224 \\
(1.45)\end{array}$ & $\begin{array}{l}-0.1341 \\
(-0.90)\end{array}$ \\
\hline $1961-77$ & 0.9681 & $\ldots$ & $\begin{array}{l}0.0317 \\
(0.33)\end{array}$ & $\begin{array}{l}0.0499 \\
(9.33)\end{array}$ & $\begin{array}{l}0.9910 \\
(7.81)\end{array}$ & $\begin{array}{l}-0.1499 \\
(-1.48)\end{array}$ & $\begin{array}{l}0.3041 \\
(3.16)\end{array}$ & $\begin{array}{l}0.0480 \\
(1.17)\end{array}$ \\
\hline $1961-67$ & 0.9631 & $\cdots$ & $\begin{array}{l}1.0283 \\
(7.25)\end{array}$ & $\begin{array}{l}0.0056 \\
(0.61)\end{array}$ & $\begin{array}{l}0.3371 \\
(1.52)\end{array}$ & $\begin{array}{l}0.0456 \\
(0.52)\end{array}$ & $\begin{array}{l}0.3157 \\
(2.46)\end{array}$ & $\begin{array}{l}0.2143 \\
(3.22)\end{array}$ \\
\hline $1968-77$ & 0.9715 & $\ldots$ & $\begin{array}{l}-0.4504 \\
(-3.15)\end{array}$ & $\begin{array}{l}0.0526 \\
(7.75)\end{array}$ & $\begin{array}{c}0.9950 \\
(5.91)\end{array}$ & $\begin{array}{l}-0.0465 \\
(-0.37)\end{array}$ & $\begin{array}{l}0.2739 \\
(1.98)\end{array}$ & $\begin{array}{l}-0.0408 \\
(-0.80)\end{array}$ \\
\hline
\end{tabular}

Source: Estimations by the authors. The aggregate internal rate used in the discounting is from the column for the constant-capital case in table 7 . 


\begin{tabular}{|c|c|c|c|c|c|c|c|c|c|}
\hline \multicolumn{9}{|l|}{ variable } & \multirow[b]{2}{*}{$R^{2}$} \\
\hline CSALES & $R D E P$ & $G R A T E$ & $C G R A T E$ & $R I N V$ & $B L O A T 1$ & $B L O A T 2$ & $B L O A T 3$ & GROWTH & \\
\hline $\begin{array}{l}0.0599 \\
(0.13)\end{array}$ & $\begin{array}{l}2.6466 \\
(3.41)\end{array}$ & $\begin{array}{l}2.3721 \\
(3.45)\end{array}$ & $\begin{array}{l}0.5713 \\
(0.60)\end{array}$ & $\begin{array}{l}1.3424 \\
(1.04)\end{array}$ & $\begin{array}{l}-8.6496 \\
(-1.13)\end{array}$ & $\begin{array}{l}-1.4423 \\
(-0.63)\end{array}$ & $\begin{array}{l}-0.0881 \\
(-0.16)\end{array}$ & $\ldots$ & 0.38 \\
\hline $\begin{array}{l}0.4863 \\
(1.35)\end{array}$ & $\begin{array}{l}0.8767 \\
(1.51)\end{array}$ & $\begin{array}{l}1.8572 \\
(2.69)\end{array}$ & $\begin{array}{l}-1.1892 \\
(-1.03)\end{array}$ & $\begin{array}{l}3.3188 \\
(3.57)\end{array}$ & $\begin{array}{l}-3.3174 \\
(-0.64)\end{array}$ & $\begin{array}{l}0.6176 \\
(0.36)\end{array}$ & $\begin{array}{l}1.0243 \\
(2.05)\end{array}$ & $\cdots$ & 0.35 \\
\hline $\begin{array}{l}0.1163 \\
(0.30)\end{array}$ & $\begin{array}{l}1.2269 \\
(2.62)\end{array}$ & $\begin{array}{l}2.0575 \\
(2.33)\end{array}$ & $\begin{array}{l}-0.7364 \\
(-0.61)\end{array}$ & $\begin{array}{l}1.3786 \\
(1.52)\end{array}$ & $\begin{array}{c}2.3196 \\
(0.14)\end{array}$ & $\begin{array}{l}-1.0280 \\
(-0.71)\end{array}$ & $\begin{array}{l}1.0461 \\
(2.58)\end{array}$ & $\begin{array}{l}0.3861 \\
(0.24)\end{array}$ & 0.41 \\
\hline $\begin{array}{l}0.5437 \\
(1.60)\end{array}$ & $\begin{array}{l}1.0798 \\
(2.67)\end{array}$ & $\begin{array}{l}2.7171 \\
(4.31)\end{array}$ & $\begin{array}{l}-3.0847 \\
(-2.94)\end{array}$ & $\begin{array}{l}0.7999 \\
(1.16)\end{array}$ & $\begin{array}{l}-10.3018 \\
(-1.57)\end{array}$ & $\begin{array}{l}2.8601 \\
(2.36)\end{array}$ & $\begin{array}{l}1.0824 \\
(3.05)\end{array}$ & $\begin{array}{l}-0.5977 \\
(-0.42)\end{array}$ & 0.46 \\
\hline $\begin{array}{l}-0.2188 \\
(-0.62)\end{array}$ & $\begin{array}{l}1.3617 \\
(2.92)\end{array}$ & $\begin{array}{l}0.9456 \\
(1.17)\end{array}$ & $\begin{array}{l}-0.8944 \\
(-0.60)\end{array}$ & $\begin{array}{l}0.9359 \\
(1.13)\end{array}$ & $\begin{array}{l}0.2734 \\
(0.07)\end{array}$ & $\begin{array}{l}-0.0414 \\
(-0.03)\end{array}$ & $\begin{array}{l}1.2941 \\
(2.93)\end{array}$ & $\begin{array}{l}4.6542 \\
(2.29)\end{array}$ & 0.52 \\
\hline $\begin{array}{l}0.3405 \\
(1.63)\end{array}$ & $\begin{array}{l}0.9572 \\
(2.40)\end{array}$ & $\begin{array}{l}2.1053 \\
(3.35)\end{array}$ & $\begin{array}{l}-2.8764 \\
(-2.59)\end{array}$ & $\begin{array}{l}0.6588 \\
(0.97)\end{array}$ & $\begin{array}{l}1.7549 \\
(0.70)\end{array}$ & $\begin{array}{l}1.7262 \\
(1.15)\end{array}$ & $\begin{array}{l}1.2198 \\
(3.22)\end{array}$ & $\begin{array}{l}-0.2393 \\
(-0.22)\end{array}$ & 0.39 \\
\hline $\begin{array}{l}0.2040 \\
(0.69)\end{array}$ & $\begin{array}{l}0.5716 \\
(1.36)\end{array}$ & $\begin{array}{l}2.3447 \\
(3.74)\end{array}$ & $\begin{array}{l}-1.3334 \\
(-1.01)\end{array}$ & $\begin{array}{l}2.0373 \\
(3.27)\end{array}$ & $\begin{array}{l}0.3523 \\
(0.37)\end{array}$ & $\begin{array}{l}1.5886 \\
(0.92)\end{array}$ & $\begin{array}{l}1.8470 \\
(4.36)\end{array}$ & $\begin{array}{l}-0.5046 \\
(-0.41)\end{array}$ & 0.52 \\
\hline $\begin{array}{l}0.5061 \\
(1.29)\end{array}$ & $\begin{array}{l}1.3247 \\
(2.69)\end{array}$ & $\begin{array}{l}2.4211 \\
(3.09)\end{array}$ & $\begin{array}{l}-1.8979 \\
(-1.29)\end{array}$ & $\begin{array}{l}0.9139 \\
(1.37)\end{array}$ & $\begin{array}{l}1.2681 \\
(1.02)\end{array}$ & $\begin{array}{l}1.9235 \\
(0.88)\end{array}$ & $\begin{array}{l}1.2512 \\
(2.69)\end{array}$ & $\begin{array}{l}2.1638 \\
(1.24)\end{array}$ & 0.47 \\
\hline $\begin{array}{l}0.4775 \\
(1.42)\end{array}$ & $\begin{array}{l}1.2039 \\
(2.30)\end{array}$ & $\begin{array}{l}2.5169 \\
(2.79)\end{array}$ & $\begin{array}{l}-3.4886 \\
(-2.39)\end{array}$ & $\begin{array}{l}0.6271 \\
(0.77)\end{array}$ & $\begin{array}{l}0.9058 \\
(0.73)\end{array}$ & $\begin{array}{l}0.0468 \\
(0.02)\end{array}$ & $\begin{array}{l}1.5021 \\
(3.21)\end{array}$ & $\begin{array}{l}2.0400 \\
(1.16)\end{array}$ & 0.54 \\
\hline $\begin{array}{l}0.6673 \\
(2.12)\end{array}$ & $\begin{array}{l}1.3442 \\
(2.98)\end{array}$ & $\begin{array}{l}2.4762 \\
(3.17)\end{array}$ & $\begin{array}{l}-2.4865 \\
(-2.04)\end{array}$ & $\begin{array}{l}0.1290 \\
(0.17)\end{array}$ & $\begin{array}{l}0.1250 \\
(0.12)\end{array}$ & $\begin{array}{l}-0.9238 \\
(-0.45)\end{array}$ & $\begin{array}{l}1.5595 \\
(3.58)\end{array}$ & $\begin{array}{l}1.4887 \\
(0.95)\end{array}$ & 0.42 \\
\hline $\begin{array}{c}0.7011 \\
(1.68)\end{array}$ & $\begin{array}{l}0.8235 \\
(1.38)\end{array}$ & $\begin{array}{l}3.6623 \\
(3.90)\end{array}$ & $\begin{array}{l}-4.3769 \\
(-2.35)\end{array}$ & $\begin{array}{l}2.1701 \\
(2.21)\end{array}$ & $\begin{array}{l}-0.5724 \\
(-0.76)\end{array}$ & $\begin{array}{l}1.7815 \\
(0.70)\end{array}$ & $\begin{array}{l}1.8610 \\
(3.36)\end{array}$ & $\begin{array}{l}0.4553 \\
(0.26)\end{array}$ & 0.41 \\
\hline $\begin{array}{l}0.3778 \\
(1.04)\end{array}$ & $\begin{array}{l}-0.3006 \\
(-0.65)\end{array}$ & $\begin{array}{l}1.8446 \\
(2.34)\end{array}$ & $\begin{array}{l}-2.2380 \\
(-1.70)\end{array}$ & $\begin{array}{l}1.6958 \\
(1.76)\end{array}$ & $\begin{array}{l}-0.9992 \\
(-1.30)\end{array}$ & $\begin{array}{l}3.9921 \\
(2.15)\end{array}$ & $\begin{array}{l}1.6916 \\
(3.99)\end{array}$ & $\begin{array}{l}1.6321 \\
(0.99)\end{array}$ & 0.40 \\
\hline $\begin{array}{l}0.1213 \\
(0.29)\end{array}$ & $\begin{array}{l}-0.1680 \\
(-0.31)\end{array}$ & $\begin{array}{l}2.1493 \\
(2.09)\end{array}$ & $\begin{array}{l}-4.1401 \\
(-2.71)\end{array}$ & $\begin{array}{l}2.1901 \\
(2.19)\end{array}$ & $\begin{array}{l}-1.5537 \\
(-1.99)\end{array}$ & $\begin{array}{l}1.3945 \\
(0.67)\end{array}$ & $\begin{array}{l}1.9712 \\
(4.08)\end{array}$ & $\begin{array}{l}1.9220 \\
(0.83)\end{array}$ & 0.46 \\
\hline $\begin{array}{l}-0.4070 \\
(-0.82)\end{array}$ & $\begin{array}{l}0.1342 \\
(0.20)\end{array}$ & $\begin{array}{l}2.4531 \\
(2.27)\end{array}$ & $\begin{array}{l}1.7646 \\
(0.75)\end{array}$ & $\begin{array}{l}4.0082 \\
(3.01)\end{array}$ & $\begin{array}{l}-1.6103 \\
(-1.81)\end{array}$ & $\begin{array}{l}-0.0562 \\
(-0.02)\end{array}$ & $\begin{array}{l}2.3464 \\
(3.51)\end{array}$ & $\begin{array}{l}1.9181 \\
(0.68)\end{array}$ & 0.44 \\
\hline $\begin{array}{c}0.6637 \\
(1.13)\end{array}$ & $\begin{array}{l}0.1513 \\
(0.17)\end{array}$ & $\begin{array}{l}1.6816 \\
(1.34)\end{array}$ & $\begin{array}{l}-7.6907 \\
(-2.92)\end{array}$ & $\begin{array}{l}3.7672 \\
(2.53)\end{array}$ & $\begin{array}{l}-0.9035 \\
(-1.52)\end{array}$ & $\begin{array}{l}0.1121 \\
(0.04)\end{array}$ & $\begin{array}{l}1.3192 \\
(1.39)\end{array}$ & $\begin{array}{l}0.5734 \\
(0.19)\end{array}$ & 0.41 \\
\hline $\begin{array}{l}0.0309 \\
(0.11)\end{array}$ & $\begin{array}{l}0.5478 \\
(0.73)\end{array}$ & $\begin{array}{l}-0.5997 \\
(-0.54)\end{array}$ & $\begin{array}{l}-3.8319 \\
(-3.05)\end{array}$ & $\begin{array}{l}4.0772 \\
(3.95)\end{array}$ & $\begin{array}{l}-0.0287 \\
(-0.08)\end{array}$ & $\begin{array}{l}0.5878 \\
(0.23)\end{array}$ & $\begin{array}{l}2.9868 \\
(3.43)\end{array}$ & $\begin{array}{l}4.8977 \\
(2.45)\end{array}$ & 0.45 \\
\hline $\begin{array}{l}0.1340 \\
(0.42)\end{array}$ & $\begin{array}{l}1.5418 \\
(2.42)\end{array}$ & $\begin{array}{l}-0.4196 \\
(-0.35)\end{array}$ & $\begin{array}{l}-2.8054 \\
(-2.55)\end{array}$ & $\begin{array}{l}1.7693 \\
(1.68)\end{array}$ & $\begin{array}{l}-0.4399 \\
(-0.56)\end{array}$ & $\begin{array}{l}-1.2779 \\
(-0.73)\end{array}$ & $\begin{array}{l}2.5878 \\
(3.47)\end{array}$ & $\begin{array}{l}9.8149 \\
(3.40)\end{array}$ & 0.52 \\
\hline $\begin{array}{c}0.1251 \\
(0.54)\end{array}$ & $\begin{array}{l}1.9855 \\
(3.86)\end{array}$ & $\begin{array}{c}0.4122 \\
(0.51)\end{array}$ & $\begin{array}{l}0.0190 \\
(0.02)\end{array}$ & $\begin{array}{l}0.4005 \\
(0.51)\end{array}$ & $\begin{array}{l}-0.0571 \\
(-0.13)\end{array}$ & $\begin{array}{l}-2.4630 \\
(-1.88)\end{array}$ & $\begin{array}{l}2.5683 \\
(4.86)\end{array}$ & $\begin{array}{l}4.9730 \\
(3.05)\end{array}$ & 0.63 \\
\hline $\begin{array}{l}-0.0681 \\
(-0.20)\end{array}$ & $\begin{array}{l}0.6365 \\
(1.31)\end{array}$ & $\begin{array}{l}-0.0647 \\
(-0.09)\end{array}$ & $\begin{array}{l}0.5610 \\
(0.40)\end{array}$ & $\begin{array}{l}1.0827 \\
(1.32)\end{array}$ & $\begin{array}{l}-0.8398 \\
(-1.98)\end{array}$ & $\begin{array}{l}-0.3870 \\
(-0.31)\end{array}$ & $\begin{array}{l}1.9341 \\
(3.92)\end{array}$ & $\begin{array}{l}5.4164 \\
(3.67)\end{array}$ & 0.76 \\
\hline $\begin{array}{l}0.2495 \\
(3.08)\end{array}$ & $\begin{array}{l}0.3623 \\
(3.12)\end{array}$ & $\begin{array}{c}2.0208 \\
(10.73)\end{array}$ & $\begin{array}{l}-1.9866 \\
(-6.43)\end{array}$ & $\begin{array}{c}1.9829 \\
(9.60)\end{array}$ & $\begin{array}{l}-0.2129 \\
(-1.43)\end{array}$ & $\begin{array}{l}1.2253 \\
(3.60)\end{array}$ & $\begin{array}{c}1.6179 \\
(13.77)\end{array}$ & $\begin{array}{l}1.4918 \\
(3.58)\end{array}$ & 0.37 \\
\hline $\begin{array}{l}0.3102 \\
(2.70)\end{array}$ & $\begin{array}{l}0.9106 \\
(5.54)\end{array}$ & $\begin{array}{l}2.2738 \\
(8.41)\end{array}$ & $\begin{array}{l}-2.4988 \\
(-5.64)\end{array}$ & $\begin{array}{l}1.2326 \\
(4.61)\end{array}$ & $\begin{array}{l}1.1700 \\
(2.05)\end{array}$ & $\begin{array}{l}1.1414 \\
(2.02)\end{array}$ & $\begin{array}{l}1.2742 \\
(8.35)\end{array}$ & $\begin{array}{l}0.4141 \\
(0.76)\end{array}$ & 0.43 \\
\hline $\begin{array}{l}0.2515 \\
(2.30)\end{array}$ & $\begin{array}{l}0.1234 \\
(0.74)\end{array}$ & $\begin{array}{l}2.2414 \\
(8.14)\end{array}$ & $\begin{array}{l}-2.2468 \\
(-5.38)\end{array}$ & $\begin{array}{l}2.5692 \\
(8.35)\end{array}$ & $\begin{array}{l}-0.3747 \\
(-2.27)\end{array}$ & $\begin{array}{l}2.0633 \\
(4.25)\end{array}$ & $\begin{array}{l}1.9228 \\
(10.44)\end{array}$ & $\begin{array}{l}2.6561 \\
(4.26)\end{array}$ & 0.38 \\
\hline
\end{tabular}

a. For a description of model 4 , see table 8 , note a. For a description of the variables see table 10 , note a. The GROWTH variable is the percentage change in the firm's net capital stock between year $t$ and $t-3$ multiplied by the firm's 'tet rate of return in year $t$. The numbers in parentheses are $t$-statistics. 
Table 12. $Z$ Regressions, Model 7, Constant-Capital Case, Aggregate Internal Rate Discounting, 1959-77

\begin{tabular}{|c|c|c|c|c|c|c|c|c|}
\hline \multirow{2}{*}{$\begin{array}{l}\text { Year and } \\
\text { period }\end{array}$} & \multicolumn{8}{|c|}{ Independent } \\
\hline & Mean $Z$ & Constant & $R I S K$ & ORISK & FIVE & $P I N T$ & $D I V$ & $C D I V$ \\
\hline 1959 & 0.9358 & $\begin{array}{l}0.2650 \\
(0.64)\end{array}$ & $\begin{array}{l}0.4340 \\
(0.70)\end{array}$ & $\begin{array}{l}-0.0525 \\
(-1.54)\end{array}$ & $\begin{array}{l}-0.5150 \\
(-0.71)\end{array}$ & $\begin{array}{l}-0.3805 \\
(-0.53)\end{array}$ & $\begin{array}{l}-0.1444 \\
(-0.37)\end{array}$ & $\begin{array}{l}0.0049 \\
(0.03)\end{array}$ \\
\hline 1960 & 0.9810 & $\begin{array}{l}-0.1340 \\
(-0.30)\end{array}$ & $\begin{array}{l}0.4824 \\
(0.80)\end{array}$ & $\begin{array}{l}-0.0527 \\
(-1.34)\end{array}$ & $\begin{array}{l}0.5055 \\
(0.73)\end{array}$ & $\begin{array}{l}-0.4882 \\
(-0.80)\end{array}$ & $\begin{array}{l}0.0789 \\
(0.19)\end{array}$ & $\begin{array}{l}0.0005 \\
(0.00)\end{array}$ \\
\hline 1961 & 0.9054 & $\begin{array}{l}0.3483 \\
(0.79)\end{array}$ & $\begin{array}{l}0.8852 \\
(1.76)\end{array}$ & $\begin{array}{l}-0.0151 \\
(-0.47)\end{array}$ & $\begin{array}{l}-0.5141 \\
(-0.53)\end{array}$ & $\begin{array}{l}-0.8268 \\
(-1.44)\end{array}$ & $\begin{array}{l}-0.0606 \\
(-0.17)\end{array}$ & $\begin{array}{l}0.3148 \\
(1.47)\end{array}$ \\
\hline 1962 & 0.9153 & $\begin{array}{l}0.0835 \\
(0.25)\end{array}$ & $\begin{array}{l}0.1615 \\
(0.32)\end{array}$ & $\begin{array}{l}-0.0358 \\
(-1.03)\end{array}$ & $\begin{array}{l}0.2790 \\
(0.40)\end{array}$ & $\begin{array}{l}-0.6128 \\
(-1.33)\end{array}$ & $\begin{array}{l}0.0933 \\
(0.32)\end{array}$ & $\begin{array}{l}0.2635 \\
(1.89)\end{array}$ \\
\hline 1963 & 0.8819 & $\begin{array}{l}0.0921 \\
(0.22)\end{array}$ & $\begin{array}{l}0.2124 \\
(0.43)\end{array}$ & $\begin{array}{l}-0.0358 \\
(-1.04)\end{array}$ & $\begin{array}{l}0.0217 \\
(0.03)\end{array}$ & $\begin{array}{l}-0.3322 \\
(-0.63)\end{array}$ & $\begin{array}{l}0.6549 \\
(1.78)\end{array}$ & $\begin{array}{l}0.1894 \\
(0.84)\end{array}$ \\
\hline 1964 & 0.8688 & $\begin{array}{l}0.3242 \\
(0.99)\end{array}$ & $\begin{array}{l}-0.5752 \\
(-1.49)\end{array}$ & $\begin{array}{l}-0.0897 \\
(-3.42)\end{array}$ & $\begin{array}{l}-0.4149 \\
(-0.58)\end{array}$ & $\begin{array}{l}-0.0418 \\
(-0.10)\end{array}$ & $\begin{array}{l}0.1343 \\
(0.45)\end{array}$ & $\begin{array}{l}-0.0543 \\
(-0.31)\end{array}$ \\
\hline 1965 & 0.9618 & $\begin{array}{l}0.3917 \\
(1.16)\end{array}$ & $\begin{array}{l}-0.6678 \\
(-1.53)\end{array}$ & $\begin{array}{l}-0.0875 \\
(-2.72)\end{array}$ & $\begin{array}{l}-0.1818 \\
(-0.23)\end{array}$ & $\begin{array}{l}0.0448 \\
(0.11)\end{array}$ & $\begin{array}{l}-0.1417 \\
(-0.43)\end{array}$ & $\begin{array}{l}0.1366 \\
(1.20)\end{array}$ \\
\hline 1966 & 0.9826 & $\begin{array}{l}-0.3451 \\
(-0.76)\end{array}$ & $\begin{array}{l}-0.9546 \\
(-1.73)\end{array}$ & $\begin{array}{l}-0.1113 \\
(-2.37)\end{array}$ & $\begin{array}{c}0.7769 \\
(0.81)\end{array}$ & $\begin{array}{l}0.0345 \\
(0.07)\end{array}$ & $\begin{array}{l}-0.0052 \\
(-0.01)\end{array}$ & $\begin{array}{l}0.0295 \\
(0.12)\end{array}$ \\
\hline 1967 & 0.9216 & $\begin{array}{l}0.1115 \\
(0.27)\end{array}$ & $\begin{array}{l}-0.3543 \\
(-0.69)\end{array}$ & $\begin{array}{l}-0.0247 \\
(-0.69)\end{array}$ & $\begin{array}{l}-0.4482 \\
(-0.44)\end{array}$ & $\begin{array}{l}0.0122 \\
(0.02)\end{array}$ & $\begin{array}{l}-0.7437 \\
(-1.85)\end{array}$ & $\begin{array}{l}0.2946 \\
(1.21)\end{array}$ \\
\hline 1968 & 1.0175 & $\begin{array}{l}0.2108 \\
(0.54)\end{array}$ & $\begin{array}{l}-0.2178 \\
(-0.48)\end{array}$ & $\begin{array}{l}0.0570 \\
(1.99)\end{array}$ & $\begin{array}{l}-0.2926 \\
(-0.37)\end{array}$ & $\begin{array}{l}-0.2200 \\
(-0.50)\end{array}$ & $\begin{array}{l}-0.3427 \\
(-0.86)\end{array}$ & $\begin{array}{c}0.1098 \\
(0.46)\end{array}$ \\
\hline 1969 & 1.0107 & $\begin{array}{l}0.4659 \\
(1.01)\end{array}$ & $\begin{array}{l}-0.7230 \\
(-1.33)\end{array}$ & $\begin{array}{l}0.0118 \\
(0.33)\end{array}$ & $\begin{array}{l}-1.7651 \\
(-2.22)\end{array}$ & $\begin{array}{l}-0.0801 \\
(-0.17)\end{array}$ & $\begin{array}{l}-0.3388 \\
(-0.73)\end{array}$ & $\begin{array}{l}-0.0283 \\
(-0.11)\end{array}$ \\
\hline 1970 & 0.9312 & $\begin{array}{l}0.3480 \\
(1.01)\end{array}$ & $\begin{array}{l}0.0369 \\
(0.10)\end{array}$ & $\begin{array}{l}-0.0029 \\
(-0.14)\end{array}$ & $\begin{array}{l}-0.4771 \\
(-0.78)\end{array}$ & $\begin{array}{l}-0.1627 \\
(-0.52)\end{array}$ & $\begin{array}{l}-0.0492 \\
(-0.14)\end{array}$ & $\begin{array}{c}0.1801 \\
(1.30)\end{array}$ \\
\hline 1971 & 0.9747 & $\begin{array}{l}0.7700 \\
(2.07)\end{array}$ & $\begin{array}{l}0.6457 \\
(1.89)\end{array}$ & $\begin{array}{l}0.0185 \\
(0.98)\end{array}$ & $\begin{array}{l}-0.2530 \\
(-0.44)\end{array}$ & $\begin{array}{l}-0.8210 \\
(-1.97)\end{array}$ & $\begin{array}{l}-0.7976 \\
(-2.08)\end{array}$ & $\begin{array}{l}-0.0202 \\
(-0.15)\end{array}$ \\
\hline 1972 & 0.9406 & $\begin{array}{l}0.6476 \\
(1.54)\end{array}$ & $\begin{array}{l}-0.3478 \\
(-0.91)\end{array}$ & $\begin{array}{l}0.0158 \\
(0.70)\end{array}$ & $\begin{array}{l}-0.8510 \\
(-1.29)\end{array}$ & $\begin{array}{l}-0.7711 \\
(-1.51)\end{array}$ & $\begin{array}{l}-0.7451 \\
(-1.55)\end{array}$ & $\begin{array}{c}0.0439 \\
(0.28)\end{array}$ \\
\hline 1973 & 1.0361 & $\begin{array}{l}1.4849 \\
(2.30)\end{array}$ & $\begin{array}{l}-1.8927 \\
(-2.67)\end{array}$ & $\begin{array}{l}-0.1190 \\
(-1.76)\end{array}$ & $\begin{array}{l}-1.3075 \\
(-1.50)\end{array}$ & $\begin{array}{l}-1.3817 \\
(-1.96)\end{array}$ & $\begin{array}{l}-1.1005 \\
(-1.37)\end{array}$ & $\begin{array}{l}0.1121 \\
(0.61)\end{array}$ \\
\hline 1974 & 1.2069 & $\begin{array}{l}1.6898 \\
(2.84)\end{array}$ & $\begin{array}{l}-1.9024 \\
(-1.72)\end{array}$ & $\begin{array}{l}-0.2085 \\
(-2.51)\end{array}$ & $\begin{array}{l}-1.8672 \\
(-2.33)\end{array}$ & $\begin{array}{l}-0.5368 \\
(-1.29)\end{array}$ & $\begin{array}{c}0.8498 \\
(1.38)\end{array}$ & $\begin{array}{l}0.2829 \\
(0.84)\end{array}$ \\
\hline 1975 & 0.9621 & $\begin{array}{l}-0.2538 \\
(-0.73)\end{array}$ & $\begin{array}{l}-0.0823 \\
(-0.16)\end{array}$ & $\begin{array}{l}-0.0560 \\
(-1.55)\end{array}$ & $\begin{array}{l}0.9448 \\
(2.07)\end{array}$ & $\begin{array}{l}-0.4906 \\
(-1.41)\end{array}$ & $\begin{array}{l}1.0640 \\
(2.42)\end{array}$ & $\begin{array}{l}-0.1918 \\
(-1.42)\end{array}$ \\
\hline 1976 & 0.9083 & $\begin{array}{l}-0.1159 \\
(-0.37)\end{array}$ & $\begin{array}{l}-0.7357 \\
(-2.08)\end{array}$ & $\begin{array}{l}0.0041 \\
(0.17)\end{array}$ & $\begin{array}{l}0.9258 \\
(2.17)\end{array}$ & $\begin{array}{l}-0.5748 \\
(-1.65)\end{array}$ & $\begin{array}{l}0.9641 \\
(2.07)\end{array}$ & $\begin{array}{l}0.0290 \\
(0.23)\end{array}$ \\
\hline 1977 & 0.9366 & $\begin{array}{l}0.1677 \\
(0.76)\end{array}$ & $\begin{array}{l}-0.9029 \\
(-3.88)\end{array}$ & $\begin{array}{l}-0.0396 \\
(-1.97)\end{array}$ & $\begin{array}{l}0.7592 \\
(2.46)\end{array}$ & $\begin{array}{l}-0.1639 \\
(-0.68)\end{array}$ & $\begin{array}{l}0.8860 \\
(3.30)\end{array}$ & $\begin{array}{c}0.0604 \\
(0.55)\end{array}$ \\
\hline $1961-77$ & 0.9563 & $\ldots$ & $\begin{array}{l}-0.1296 \\
(-1.26)\end{array}$ & $\begin{array}{l}-0.0106 \\
(-1.46)\end{array}$ & $\begin{array}{l}0.0022 \\
(0.01)\end{array}$ & $\begin{array}{l}-0.2269 \\
(-2.29)\end{array}$ & $\begin{array}{l}0.0947 \\
(1.01)\end{array}$ & $\begin{array}{l}0.0252 \\
(0.63)\end{array}$ \\
\hline $1961-67$ & 0.9176 & $\cdots$ & $\begin{array}{l}-0.1507 \\
(-0.91)\end{array}$ & $\begin{array}{l}-0.0403 \\
(-3.42)\end{array}$ & $\begin{array}{l}-0.0033 \\
(-0.01)\end{array}$ & $\begin{array}{l}-0.1008 \\
(-0.58)\end{array}$ & $\begin{array}{l}0.0596 \\
(0.49)\end{array}$ & $\begin{array}{l}0.1700 \\
(2.65)\end{array}$ \\
\hline $1968-77$ & 0.9834 & $\cdots$ & $\begin{array}{l}-0.1257 \\
(-0.95)\end{array}$ & $\begin{array}{l}-0.0017 \\
(-0.19)\end{array}$ & $\begin{array}{l}-0.0899 \\
(-0.47)\end{array}$ & $\begin{array}{l}-0.1786 \\
(-1.42)\end{array}$ & $\begin{array}{l}-0.0009 \\
(-0.01)\end{array}$ & $\begin{array}{l}-0.0363 \\
(-0.71)\end{array}$ \\
\hline
\end{tabular}

Source: Same as table 11 .

a. See text for a description of model 7. The variables are described in tables 10 and 11 . The numbers in parentheses are $t$-statistics. 


\begin{tabular}{|c|c|c|c|c|c|c|c|c|c|}
\hline \multicolumn{9}{|l|}{ variable } & \multirow[b]{2}{*}{$R^{2}$} \\
\hline$C S A L E S$ & $R D E P$ & GRATE & CGRATE & $R I N V$ & $B L O A T 1$ & $B L O A T 2$ & $B L O A T 3$ & GROWTH & \\
\hline $\begin{array}{l}0.4727 \\
(1.15)\end{array}$ & $\begin{array}{l}1.1889 \\
(1.84)\end{array}$ & $\begin{array}{l}1.9175 \\
(3.21)\end{array}$ & $\begin{array}{l}0.8455 \\
(0.95)\end{array}$ & $\begin{array}{l}2.2267 \\
(1.97)\end{array}$ & $\begin{array}{l}-4.5735 \\
(-0.69)\end{array}$ & $\begin{array}{l}-1.9328 \\
(-0.96)\end{array}$ & $\begin{array}{l}0.8215 \\
(1.67)\end{array}$ & $\begin{array}{l}0.0000 \\
(0.00)\end{array}$ & 0.37 \\
\hline $\begin{array}{l}0.4547 \\
(1.23)\end{array}$ & $\begin{array}{l}-0.0864 \\
(-0.15)\end{array}$ & $\begin{array}{l}2.4303 \\
(3.43)\end{array}$ & $\begin{array}{l}-1.0561 \\
(-0.89)\end{array}$ & $\begin{array}{l}5.6115 \\
(5.71)\end{array}$ & $\begin{array}{l}-6.7646 \\
(-1.28)\end{array}$ & $\begin{array}{l}1.4231 \\
(0.77)\end{array}$ & $\begin{array}{l}1.3087 \\
(2.53)\end{array}$ & $\begin{array}{l}0.0000 \\
(0.00)\end{array}$ & 0.49 \\
\hline $\begin{array}{l}0.7871 \\
(1.86)\end{array}$ & $\begin{array}{c}0.4302 \\
(0.92)\end{array}$ & $\begin{array}{l}3.0324 \\
(3.30)\end{array}$ & $\begin{array}{l}-1.9858 \\
(-1.55)\end{array}$ & $\begin{array}{l}2.5400 \\
(2.69)\end{array}$ & $\begin{array}{l}0.9182 \\
(0.05)\end{array}$ & $\begin{array}{l}-1.7358 \\
(-1.01)\end{array}$ & $\begin{array}{l}1.1623 \\
(2.77)\end{array}$ & $\begin{array}{l}-1.2913 \\
(-0.80)\end{array}$ & 0.52 \\
\hline $\begin{array}{l}0.4769 \\
(1.27)\end{array}$ & $\begin{array}{l}0.5598 \\
(1.35)\end{array}$ & $\begin{array}{l}2.9995 \\
(4.30)\end{array}$ & $\begin{array}{l}-3.2950 \\
(-2.84)\end{array}$ & $\begin{array}{l}1.9821 \\
(2.62)\end{array}$ & $\begin{array}{l}-5.3690 \\
(-0.75)\end{array}$ & $\begin{array}{l}-0.9672 \\
(-0.66)\end{array}$ & $\begin{array}{l}1.2162 \\
(3.26)\end{array}$ & $\begin{array}{l}-1.6501 \\
(-1.09)\end{array}$ & 0.54 \\
\hline $\begin{array}{l}0.0012 \\
(0.00)\end{array}$ & $\begin{array}{l}0.7204 \\
(1.71)\end{array}$ & $\begin{array}{l}1.7004 \\
(2.20)\end{array}$ & $\begin{array}{l}-1.0636 \\
(-0.76)\end{array}$ & $\begin{array}{l}1.9601 \\
(2.53)\end{array}$ & $\begin{array}{c}-1.1784 \\
(-0.31)\end{array}$ & $\begin{array}{l}-1.7940 \\
(-1.12)\end{array}$ & $\begin{array}{l}1.4971 \\
(3.65)\end{array}$ & $\begin{array}{l}2.8041 \\
(1.48)\end{array}$ & 0.50 \\
\hline $\begin{array}{l}0.5296 \\
(2.87)\end{array}$ & $\begin{array}{l}0.5076 \\
(1.49)\end{array}$ & $\begin{array}{l}2.8795 \\
(5.24)\end{array}$ & $\begin{array}{l}-2.4489 \\
(-2.55)\end{array}$ & $\begin{array}{l}1.5002 \\
(2.49)\end{array}$ & $\begin{array}{l}2.0628 \\
(0.94)\end{array}$ & $\begin{array}{l}-0.6669 \\
(-0.46)\end{array}$ & $\begin{array}{l}1.2159 \\
(3.72)\end{array}$ & $\begin{array}{l}-1.1546 \\
(-1.22)\end{array}$ & 0.54 \\
\hline $\begin{array}{l}0.5464 \\
(1.84)\end{array}$ & $\begin{array}{l}-0.0093 \\
(-0.02)\end{array}$ & $\begin{array}{l}2.8545 \\
(4.83)\end{array}$ & $\begin{array}{l}-1.4501 \\
(-1.17)\end{array}$ & $\begin{array}{l}3.2435 \\
(5.42)\end{array}$ & $\begin{array}{l}0.4425 \\
(0.50)\end{array}$ & $\begin{array}{l}-1.0874 \\
(-0.61)\end{array}$ & $\begin{array}{l}1.8882 \\
(4.84)\end{array}$ & $\begin{array}{l}-1.2810 \\
(-1.13)\end{array}$ & 0.62 \\
\hline $\begin{array}{l}0.5714 \\
(1.38)\end{array}$ & $\begin{array}{l}0.8459 \\
(1.73)\end{array}$ & $\begin{array}{l}3.2876 \\
(3.98)\end{array}$ & $\begin{array}{l}-2.3628 \\
(-1.54)\end{array}$ & $\begin{array}{l}2.5320 \\
(3.68)\end{array}$ & $\begin{array}{l}1.2666 \\
(0.99)\end{array}$ & $\begin{array}{l}-0.9379 \\
(-0.37)\end{array}$ & $\begin{array}{l}1.3862 \\
(2.84)\end{array}$ & $\begin{array}{l}0.7285 \\
(0.40)\end{array}$ & 0.56 \\
\hline $\begin{array}{l}0.4359 \\
(1.31)\end{array}$ & $\begin{array}{l}1.0691 \\
(2.20)\end{array}$ & $\begin{array}{l}3.5785 \\
(3.87)\end{array}$ & $\begin{array}{l}-4.3423 \\
(-2.87)\end{array}$ & $\begin{array}{l}1.4743 \\
(1.89)\end{array}$ & $\begin{array}{l}0.5365 \\
(0.44)\end{array}$ & $\begin{array}{l}-2.5537 \\
(-1.00)\end{array}$ & $\begin{array}{l}1.3210 \\
(2.91)\end{array}$ & $\begin{array}{l}0.9787 \\
(0.56)\end{array}$ & 0.55 \\
\hline $\begin{array}{l}0.7985 \\
(2.46)\end{array}$ & $\begin{array}{l}0.8798 \\
(1.87)\end{array}$ & $\begin{array}{l}3.3165 \\
(3.96)\end{array}$ & $\begin{array}{l}-2.2460 \\
(-1.71)\end{array}$ & $\begin{array}{l}1.7677 \\
(2.24)\end{array}$ & $\begin{array}{l}-0.1850 \\
(-0.18)\end{array}$ & $\begin{array}{l}-3.6762 \\
(-1.44)\end{array}$ & $\begin{array}{l}1.5708 \\
(3.53)\end{array}$ & $\begin{array}{l}-0.0645 \\
(-0.04)\end{array}$ & 0.54 \\
\hline $\begin{array}{l}0.6720 \\
(1.47)\end{array}$ & $\begin{array}{c}0.8562 \\
(1.31)\end{array}$ & $\begin{array}{l}4.3089 \\
(4.20)\end{array}$ & $\begin{array}{l}-4.1642 \\
(-2.09)\end{array}$ & $\begin{array}{l}3.9880 \\
(3.81)\end{array}$ & $\begin{array}{l}-0.9565 \\
(-1.18)\end{array}$ & $\begin{array}{l}-3.4482 \\
(-1.04)\end{array}$ & $\begin{array}{l}1.9021 \\
(3.19)\end{array}$ & $\begin{array}{l}-0.8439 \\
(-0.44)\end{array}$ & 0.55 \\
\hline $\begin{array}{c}0.5931 \\
(1.66)\end{array}$ & $\begin{array}{l}0.5026 \\
(0.99)\end{array}$ & $\begin{array}{l}3.4239 \\
(4.39)\end{array}$ & $\begin{array}{l}-3.1857 \\
(-2.36)\end{array}$ & $\begin{array}{l}2.6643 \\
(2.80)\end{array}$ & $\begin{array}{l}-1.1685 \\
(-1.54)\end{array}$ & $\begin{array}{l}-2.0427 \\
(-0.92)\end{array}$ & $\begin{array}{l}1.4032 \\
(3.21)\end{array}$ & $\begin{array}{l}-0.9607 \\
(-0.59)\end{array}$ & 0.58 \\
\hline $\begin{array}{l}0.3132 \\
(0.74)\end{array}$ & $\begin{array}{l}0.3951 \\
(0.68)\end{array}$ & $\begin{array}{l}3.7508 \\
(3.76)\end{array}$ & $\begin{array}{l}-4.1512 \\
(-2.79)\end{array}$ & $\begin{array}{l}2.4741 \\
(2.52)\end{array}$ & $\begin{array}{l}-2.0874 \\
(-2.75)\end{array}$ & $\begin{array}{l}-3.3041 \\
(-1.37)\end{array}$ & $\begin{array}{l}1.6369 \\
(3.37)\end{array}$ & $\begin{array}{l}-0.1394 \\
(-0.06)\end{array}$ & 0.63 \\
\hline $\begin{array}{l}-0.2037 \\
(-0.44)\end{array}$ & $\begin{array}{l}0.5387 \\
(0.82)\end{array}$ & $\begin{array}{l}3.8289 \\
(3.70)\end{array}$ & $\begin{array}{l}2.1718 \\
(1.00)\end{array}$ & $\begin{array}{l}4.7319 \\
(3.84)\end{array}$ & $\begin{array}{l}-1.8044 \\
(-2.17)\end{array}$ & $\begin{array}{l}-3.3995 \\
(-1.24)\end{array}$ & $\begin{array}{l}2.1928 \\
(3.37)\end{array}$ & $\begin{array}{c}0.2382 \\
(0.09)\end{array}$ & 0.61 \\
\hline $\begin{array}{l}1.1389 \\
(1.84)\end{array}$ & $\begin{array}{l}1.0729 \\
(1.09)\end{array}$ & $\begin{array}{l}3.1142 \\
(2.34)\end{array}$ & $\begin{array}{l}-8.7508 \\
(-3.11)\end{array}$ & $\begin{array}{l}5.1286 \\
(3.33)\end{array}$ & $\begin{array}{l}-1.1015 \\
(-1.78)\end{array}$ & $\begin{array}{l}-5.9066 \\
(-1.55)\end{array}$ & $\begin{array}{l}1.5309 \\
(1.48)\end{array}$ & $\begin{array}{l}-1.6814 \\
(-0.53)\end{array}$ & 0.55 \\
\hline $\begin{array}{l}0.2630 \\
(0.77)\end{array}$ & $\begin{array}{l}1.4209 \\
(1.50)\end{array}$ & $\begin{array}{l}0.4120 \\
(0.31)\end{array}$ & $\begin{array}{l}-4.9911 \\
(-3.40)\end{array}$ & $\begin{array}{l}7.1550 \\
(5.58)\end{array}$ & $\begin{array}{l}-0.3099 \\
(-0.75)\end{array}$ & $\begin{array}{l}-6.6677 \\
(-1.99)\end{array}$ & $\begin{array}{l}4.0365 \\
(3.62)\end{array}$ & $\begin{array}{l}2.7315 \\
(1.14)\end{array}$ & 0.57 \\
\hline $\begin{array}{l}0.2489 \\
(0.84)\end{array}$ & $\begin{array}{l}3.9360 \\
(5.90)\end{array}$ & $\begin{array}{l}1.1676 \\
(1.01)\end{array}$ & $\begin{array}{l}-2.6454 \\
(-2.50)\end{array}$ & $\begin{array}{l}2.2440 \\
(2.23)\end{array}$ & $\begin{array}{l}-0.4645 \\
(-0.63)\end{array}$ & $\begin{array}{l}-10.4567 \\
(-5.49)\end{array}$ & $\begin{array}{l}2.1481 \\
(3.04)\end{array}$ & $\begin{array}{l}3.5718 \\
(1.31)\end{array}$ & 0.63 \\
\hline $\begin{array}{l}0.3726 \\
(1.42)\end{array}$ & $\begin{array}{l}3.4094 \\
(5.67)\end{array}$ & $\begin{array}{l}1.6204 \\
(1.76)\end{array}$ & $\begin{array}{l}0.1983 \\
(0.14)\end{array}$ & $\begin{array}{l}1.2864 \\
(1.46)\end{array}$ & $\begin{array}{l}-0.5775 \\
(-1.16)\end{array}$ & $\begin{array}{l}-9.0250 \\
(-5.58)\end{array}$ & $\begin{array}{l}2.4182 \\
(3.92)\end{array}$ & $\begin{array}{l}0.2215 \\
(0.12)\end{array}$ & 0.67 \\
\hline $\begin{array}{l}0.4253 \\
(1.69)\end{array}$ & $\begin{array}{l}2.0323 \\
(5.27)\end{array}$ & $\begin{array}{l}0.8859 \\
(1.60)\end{array}$ & $\begin{array}{l}-0.0456 \\
(-0.04)\end{array}$ & $\begin{array}{l}1.7876 \\
(2.85)\end{array}$ & $\begin{array}{l}-0.4575 \\
(-1.44)\end{array}$ & $\begin{array}{l}-5.6817 \\
(-5.48)\end{array}$ & $\begin{array}{l}1.8174 \\
(4.87)\end{array}$ & $\begin{array}{l}-0.0415 \\
(-0.04)\end{array}$ & 0.71 \\
\hline $\begin{array}{l}0.4315 \\
(5.40)\end{array}$ & $\begin{array}{c}0.6952 \\
(6.16)\end{array}$ & $\begin{array}{c}3.3611 \\
(18.04)\end{array}$ & $\begin{array}{l}-2.8016 \\
(-9.19)\end{array}$ & $\begin{array}{c}2.9888 \\
(14.69)\end{array}$ & $\begin{array}{l}-0.5817 \\
(-3.98)\end{array}$ & $\begin{array}{l}-1.8892 \\
(-5.57)\end{array}$ & $\begin{array}{c}1.3933 \\
(12.12)\end{array}$ & $\begin{array}{l}-0.3905 \\
(-0.95)\end{array}$ & 0.50 \\
\hline $\begin{array}{l}0.4600 \\
(4.14)\end{array}$ & $\begin{array}{l}0.5963 \\
(3.95)\end{array}$ & $\begin{array}{l}3.1032 \\
(11.90)\end{array}$ & $\begin{array}{l}-2.6619 \\
(-6.23)\end{array}$ & $\begin{array}{l}2.2813 \\
(8.77)\end{array}$ & $\begin{array}{l}0.7229 \\
(1.32)\end{array}$ & $\begin{array}{l}-1.0171 \\
(-1.79)\end{array}$ & $\begin{array}{l}1.2900 \\
(8.93)\end{array}$ & $\begin{array}{l}-0.7480 \\
(-1.44)\end{array}$ & 0.52 \\
\hline $\begin{array}{l}0.4370 \\
(3.97)\end{array}$ & $\begin{array}{l}0.7663 \\
(4.59)\end{array}$ & $\begin{array}{c}3.7849 \\
(13.69)\end{array}$ & $\begin{array}{l}-3.3083 \\
(-7.87)\end{array}$ & $\begin{array}{l}3.6540 \\
(11.79)\end{array}$ & $\begin{array}{l}-0.6838 \\
(-4.14)\end{array}$ & $\begin{array}{l}-2.0237 \\
(-4.08)\end{array}$ & $\begin{array}{l}1.7791 \\
(9.67)\end{array}$ & $\begin{array}{l}0.2162 \\
(0.34)\end{array}$ & 0.52 \\
\hline
\end{tabular}


Table 13. Means and Standard Deviations for Independent Variables in Cross-Sectional Regressions, 1959-77 a

\begin{tabular}{|c|c|c|c|c|c|c|c|}
\hline \multirow{2}{*}{$\begin{array}{l}\text { Year and } \\
\text { period }\end{array}$} & \multicolumn{7}{|r|}{ Independen } \\
\hline & $R I S K$ & ORISK & FIVE & PINT & $D I V$ & $C D I V$ & CSALES \\
\hline 1959 & $\begin{array}{l}0.0298 \\
(0.09)\end{array}$ & $\begin{array}{l}2.1683 \\
(1.69)\end{array}$ & $\begin{array}{l}0.2605 \\
(0.85)\end{array}$ & $\begin{array}{l}0.0756 \\
(0.05)\end{array}$ & $\begin{array}{l}0.2738 \\
(0.11)\end{array}$ & $\begin{array}{l}0.1340 \\
(0.31)\end{array}$ & $\begin{array}{l}0.1213 \\
(0.10)\end{array}$ \\
\hline 1960 & $\begin{array}{c}0.0390 \\
(0.08)\end{array}$ & $\begin{array}{l}2.2476 \\
(1.74)\end{array}$ & $\begin{array}{l}0.2657 \\
(0.93)\end{array}$ & $\begin{array}{l}0.0895 \\
(0.06)\end{array}$ & $\begin{array}{l}0.2977 \\
(0.11)\end{array}$ & $\begin{array}{l}0.0801 \\
(0.30)\end{array}$ & $\begin{array}{c}0.0409 \\
(0.12)\end{array}$ \\
\hline 1961 & $\begin{array}{l}0.0433 \\
(0.07)\end{array}$ & $\begin{array}{l}2.6144 \\
(1.33)\end{array}$ & $\begin{array}{l}0.2261 \\
(0.05)\end{array}$ & $\begin{array}{l}0.0873 \\
(0.06)\end{array}$ & $\begin{array}{l}0.2914 \\
(0.11)\end{array}$ & $\begin{array}{l}0.0469 \\
(0.15)\end{array}$ & $\begin{array}{l}0.0363 \\
(0.09)\end{array}$ \\
\hline 1962 & $\begin{array}{l}0.0384 \\
(0.07)\end{array}$ & $\begin{array}{l}1.9876 \\
(1.33)\end{array}$ & $\begin{array}{l}0.2795 \\
(0.05)\end{array}$ & $\begin{array}{l}0.0889 \\
(0.07)\end{array}$ & $\begin{array}{c}0.2852 \\
(0.11)\end{array}$ & $\begin{array}{l}0.0728 \\
(0.21)\end{array}$ & $\begin{array}{c}0.0802 \\
(0.10)\end{array}$ \\
\hline 1963 & $\begin{array}{l}0.0434 \\
(0.10)\end{array}$ & $\begin{array}{l}2.0714 \\
(1.61)\end{array}$ & $\begin{array}{l}0.2677 \\
(0.04)\end{array}$ & $\begin{array}{l}0.0850 \\
(0.06)\end{array}$ & $\begin{array}{c}0.2760 \\
(0.10)\end{array}$ & $\begin{array}{l}0.0720 \\
(0.12)\end{array}$ & $\begin{array}{l}0.0653 \\
(0.09)\end{array}$ \\
\hline 1964 & $\begin{array}{l}0.0356 \\
(0.06)\end{array}$ & $\begin{array}{l}1.9145 \\
(1.02)\end{array}$ & $\begin{array}{l}0.2594 \\
(0.03)\end{array}$ & $\begin{array}{l}0.0782 \\
(0.05)\end{array}$ & $\begin{array}{l}0.2591 \\
(0.09)\end{array}$ & $\begin{array}{l}0.1020 \\
(0.13)\end{array}$ & $\begin{array}{c}0.0997 \\
(0.14)\end{array}$ \\
\hline 1965 & $\begin{array}{l}0.0342 \\
(0.06)\end{array}$ & $\begin{array}{l}1.7390 \\
(0.91)\end{array}$ & $\begin{array}{l}0.2717 \\
(0.03)\end{array}$ & $\begin{array}{l}0.0788 \\
(0.06)\end{array}$ & $\begin{array}{l}0.2472 \\
(0.09)\end{array}$ & $\begin{array}{l}0.1356 \\
(0.19)\end{array}$ & $\begin{array}{l}0.1041 \\
(0.09)\end{array}$ \\
\hline 1966 & $\begin{array}{l}0.0344 \\
(0.06)\end{array}$ & $\begin{array}{l}1.5151 \\
(0.76)\end{array}$ & $\begin{array}{l}0.3225 \\
(0.03)\end{array}$ & $\begin{array}{l}0.0898 \\
(0.06)\end{array}$ & $\begin{array}{l}0.2490 \\
(0.09)\end{array}$ & $\begin{array}{l}0.1288 \\
(0.11)\end{array}$ & $\begin{array}{l}0.0965 \\
(0.08)\end{array}$ \\
\hline 1967 & $\begin{array}{l}0.0421 \\
(0.08)\end{array}$ & $\begin{array}{l}2.2657 \\
(1.89)\end{array}$ & $\begin{array}{l}0.2674 \\
(0.03)\end{array}$ & $\begin{array}{l}0.1069 \\
(0.06)\end{array}$ & $\begin{array}{l}0.2573 \\
(0.08)\end{array}$ & $\begin{array}{l}0.1017 \\
(0.13)\end{array}$ & $\begin{array}{l}0.0630 \\
(0.12)\end{array}$ \\
\hline 1968 & $\begin{array}{l}0.0361 \\
(0.06)\end{array}$ & $\begin{array}{l}2.0421 \\
(1.15)\end{array}$ & $\begin{array}{l}0.2861 \\
(0.04)\end{array}$ & $\begin{array}{l}0.1156 \\
(0.06)\end{array}$ & $\begin{array}{l}0.2500 \\
(0.09)\end{array}$ & $\begin{array}{l}0.0734 \\
(0.12)\end{array}$ & $\begin{array}{l}0.0815 \\
(0.10)\end{array}$ \\
\hline 1969 & $\begin{array}{l}0.0321 \\
(0.06)\end{array}$ & $\begin{array}{l}1.9385 \\
(1.09)\end{array}$ & $\begin{array}{l}0.3166 \\
(0.05)\end{array}$ & $\begin{array}{l}0.1345 \\
(0.08)\end{array}$ & $\begin{array}{l}0.2400 \\
(0.09)\end{array}$ & $\begin{array}{l}0.0615 \\
(0.14)\end{array}$ & $\begin{array}{l}0.0660 \\
(0.09)\end{array}$ \\
\hline 1970 & $\begin{array}{l}0.0372 \\
(0.08)\end{array}$ & $\begin{array}{l}2.5550 \\
(1.96)\end{array}$ & $\begin{array}{l}0.3107 \\
(0.04)\end{array}$ & $\begin{array}{l}0.1711 \\
(0.11)\end{array}$ & $\begin{array}{l}0.2408 \\
(0.09)\end{array}$ & $\begin{array}{l}0.0160 \\
(0.19)\end{array}$ & $\begin{array}{c}-0.0013 \\
(0.08)\end{array}$ \\
\hline 1971 & $\begin{array}{l}0.0396 \\
(0.08)\end{array}$ & $\begin{array}{l}2.8780 \\
(2.03)\end{array}$ & $\begin{array}{l}0.2999 \\
(0.05)\end{array}$ & $\begin{array}{l}0.1579 \\
(0.09)\end{array}$ & $\begin{array}{l}0.2197 \\
(0.09)\end{array}$ & $\begin{array}{l}0.0042 \\
(0.22)\end{array}$ & $\begin{array}{l}0.0277 \\
(0.08)\end{array}$ \\
\hline 1972 & $\begin{array}{l}0.0384 \\
(0.08)\end{array}$ & $\begin{array}{l}2.8483 \\
(1.97)\end{array}$ & $\begin{array}{l}0.2877 \\
(0.05)\end{array}$ & $\begin{array}{l}0.1415 \\
(0.08)\end{array}$ & $\begin{array}{l}0.1969 \\
(0.07)\end{array}$ & $\begin{array}{c}0.0374 \\
(0.18)\end{array}$ & $\begin{array}{l}0.0802 \\
(0.07)\end{array}$ \\
\hline 1973 & $\begin{array}{l}0.0246 \\
(0.04)\end{array}$ & $\begin{array}{l}1.2763 \\
(0.66)\end{array}$ & $\begin{array}{l}0.4091 \\
(0.05)\end{array}$ & $\begin{array}{l}0.1356 \\
(0.07)\end{array}$ & $\begin{array}{l}0.1656 \\
(0.06)\end{array}$ & $\begin{array}{l}0.1062 \\
(0.23)\end{array}$ & $\begin{array}{l}0.1057 \\
(0.09)\end{array}$ \\
\hline 1974 & $\begin{array}{l}0.0254 \\
(0.04)\end{array}$ & $\begin{array}{l}0.8336 \\
(0.43)\end{array}$ & $\begin{array}{l}0.5753 \\
(0.05)\end{array}$ & $\begin{array}{l}0.1625 \\
(0.11)\end{array}$ & $\begin{array}{l}0.1579 \\
(0.08)\end{array}$ & $\begin{array}{l}0.1150 \\
(0.12)\end{array}$ & $\begin{array}{l}0.1048 \\
(0.14)\end{array}$ \\
\hline 1975 & $\begin{array}{l}0.0342 \\
(0.07)\end{array}$ & $\begin{array}{l}1.8323 \\
(1.56)\end{array}$ & $\begin{array}{l}0.4350 \\
(0.07)\end{array}$ & $\begin{array}{l}0.1851 \\
(0.10)\end{array}$ & $\begin{array}{l}0.1829 \\
(0.07)\end{array}$ & $\begin{array}{l}0.0567 \\
(0.22)\end{array}$ & $\begin{array}{c}-0.0401 \\
(0.12)\end{array}$ \\
\hline 1976 & $\begin{array}{l}0.0337 \\
(0.09)\end{array}$ & $\begin{array}{l}1.9780 \\
(1.46)\end{array}$ & $\begin{array}{l}0.3927 \\
(0.07)\end{array}$ & $\begin{array}{l}0.1561 \\
(0.08)\end{array}$ & $\begin{array}{l}0.1758 \\
(0.07)\end{array}$ & $\begin{array}{l}0.1365 \\
(0.20)\end{array}$ & $\begin{array}{l}0.0700 \\
(0.11)\end{array}$ \\
\hline 1977 & $\begin{array}{l}0.0311 \\
(0.08)\end{array}$ & $\begin{array}{l}1.7828 \\
(2.33)\end{array}$ & $\begin{array}{l}0.4363 \\
(0.06)\end{array}$ & $\begin{array}{l}0.1565 \\
(0.08)\end{array}$ & $\begin{array}{l}0.1834 \\
(0.07)\end{array}$ & $\begin{array}{l}0.1665 \\
(0.14)\end{array}$ & $\begin{array}{l}0.0645 \\
(0.07)\end{array}$ \\
\hline $1961-77$ & $\begin{array}{c}0.0355 \\
(0.076)\end{array}$ & $\begin{array}{l}2.0038 \\
(1.60)\end{array}$ & $\begin{array}{l}0.3330 \\
(0.10)\end{array}$ & $\begin{array}{l}0.1249 \\
(0.09)\end{array}$ & $\begin{array}{l}0.2262 \\
(0.10)\end{array}$ & $\begin{array}{c}0.0832 \\
(0.18)\end{array}$ & $\begin{array}{c}0.0649 \\
(0.11)\end{array}$ \\
\hline $1961-67$ & $\begin{array}{l}0.0388 \\
(0.08)\end{array}$ & $\begin{array}{l}2.0146 \\
(1.45)\end{array}$ & $\begin{array}{c}0.2761 \\
(0.06)\end{array}$ & $\begin{array}{l}0.0875 \\
(0.07)\end{array}$ & $\begin{array}{l}0.2644 \\
(0.10)\end{array}$ & $\begin{array}{l}0.0931 \\
(0.16)\end{array}$ & $\begin{array}{c}0.0779 \\
(0.11)\end{array}$ \\
\hline $1968-77$ & $\begin{array}{l}0.0332 \\
(0.08)\end{array}$ & $\begin{array}{l}1.9962 \\
(1.69)\end{array}$ & $\begin{array}{l}0.3727 \\
(0.10)\end{array}$ & $\begin{array}{l}0.1510 \\
(0.09)\end{array}$ & $\begin{array}{l}0.1995 \\
(0.09)\end{array}$ & $\begin{array}{l}0.0763 \\
(0.19)\end{array}$ & $\begin{array}{c}0.0558 \\
(0.11)\end{array}$ \\
\hline
\end{tabular}

Source: Calculations by the authors.

a. For a description of the variables see notes to table 10. The numbers in parentheses are standard deviations 


\begin{tabular}{|c|c|c|c|c|c|c|c|}
\hline$R D E P$ & $G R A T E$ & $C G R A T E$ & $R I N V$ & $B L O A T 1$ & $B L O A T 2$ & $B L O A T 3$ & GROWTH \\
\hline $\begin{array}{l}0.4254 \\
(0.16)\end{array}$ & $\begin{array}{l}0.1786 \\
(0.09)\end{array}$ & $\begin{array}{l}0.0144 \\
(0.04)\end{array}$ & $\begin{array}{l}0.0891 \\
(0.05)\end{array}$ & $\begin{array}{c}-0.0053 \\
(0.00)\end{array}$ & $\begin{array}{l}0.0845 \\
(0.05)\end{array}$ & $\begin{array}{c}-0.0167 \\
(0.09)\end{array}$ & $\ldots$ \\
\hline $\begin{array}{l}0.4516 \\
(0.17)\end{array}$ & $\begin{array}{l}0.1651 \\
(0.08)\end{array}$ & $\begin{array}{c}-0.0134 \\
(0.03)\end{array}$ & $\begin{array}{l}0.0972 \\
(0.05)\end{array}$ & $\begin{array}{c}-0.0079 \\
(0.00)\end{array}$ & $\begin{array}{l}0.0793 \\
(0.05)\end{array}$ & $\begin{array}{c}-0.0138 \\
(0.01)\end{array}$ & $\cdots$ \\
\hline $\begin{array}{l}0.4421 \\
(0.16)\end{array}$ & $\begin{array}{l}0.1612 \\
(0.07)\end{array}$ & $\begin{array}{c}-0.0039 \\
(0.03)\end{array}$ & $\begin{array}{l}0.0815 \\
(0.04)\end{array}$ & $\begin{array}{l}0.0019 \\
(0.00)\end{array}$ & $\begin{array}{l}0.0657 \\
(0.04)\end{array}$ & $\begin{array}{c}-0.0241 \\
(0.10)\end{array}$ & $\begin{array}{l}0.0253 \\
(0.03)\end{array}$ \\
\hline $\begin{array}{l}0.4297 \\
(0.16)\end{array}$ & $\begin{array}{l}0.1656 \\
(0.08)\end{array}$ & $\begin{array}{l}0.0048 \\
(0.03)\end{array}$ & $\begin{array}{l}0.0855 \\
(0.04)\end{array}$ & $\begin{array}{c}-0.0039 \\
(0.00)\end{array}$ & $\begin{array}{l}0.0587 \\
(0.04)\end{array}$ & $\begin{array}{c}-0.0308 \\
(0.10)\end{array}$ & $\begin{array}{l}0.0222 \\
(0.02)\end{array}$ \\
\hline $\begin{array}{l}0.4133 \\
(0.15)\end{array}$ & $\begin{array}{l}0.1674 \\
(0.07)\end{array}$ & $\begin{array}{l}0.0017 \\
(0.02)\end{array}$ & $\begin{array}{l}0.0882 \\
(0.04)\end{array}$ & $\begin{array}{l}0.0083 \\
(0.00)\end{array}$ & $\begin{array}{l}0.0508 \\
(0.03)\end{array}$ & $\begin{array}{c}-0.0270 \\
(0.09)\end{array}$ & $\begin{array}{l}0.0224 \\
(0.02)\end{array}$ \\
\hline $\begin{array}{l}0.3531 \\
(0.13)\end{array}$ & $\begin{array}{l}0.1849 \\
(0.07)\end{array}$ & $\begin{array}{l}0.0085 \\
(0.02)\end{array}$ & $\begin{array}{l}0.1042 \\
(0.05)\end{array}$ & $\begin{array}{l}0.0294 \\
(0.02)\end{array}$ & $\begin{array}{l}0.0368 \\
(0.02)\end{array}$ & $\begin{array}{c}-0.0214 \\
(0.07)\end{array}$ & $\begin{array}{l}0.0368 \\
(0.03)\end{array}$ \\
\hline $\begin{array}{l}0.3560 \\
(0.13)\end{array}$ & $\begin{array}{l}0.1804 \\
(0.07)\end{array}$ & $\begin{array}{c}-0.0045 \\
(0.02)\end{array}$ & $\begin{array}{l}0.1165 \\
(0.06)\end{array}$ & $\begin{array}{l}0.0272 \\
(0.02)\end{array}$ & $\begin{array}{l}0.0391 \\
(0.02)\end{array}$ & $\begin{array}{c}-0.0174 \\
(0.07)\end{array}$ & $\begin{array}{l}0.0431 \\
(0.03)\end{array}$ \\
\hline $\begin{array}{l}0.3781 \\
(0.14)\end{array}$ & $\begin{array}{l}0.1671 \\
(0.07)\end{array}$ & $\begin{array}{c}-0.0133 \\
(0.02)\end{array}$ & $\begin{array}{l}0.1049 \\
(0.04)\end{array}$ & $\begin{array}{l}0.0312 \\
(0.02)\end{array}$ & $\begin{array}{l}0.0475 \\
(0.02)\end{array}$ & $\begin{array}{c}-0.0279 \\
(0.07)\end{array}$ & $\begin{array}{l}0.0427 \\
(0.03)\end{array}$ \\
\hline $\begin{array}{l}0.3817 \\
(0.14)\end{array}$ & $\begin{array}{l}0.1720 \\
(0.07)\end{array}$ & $\begin{array}{l}0.0048 \\
(0.02)\end{array}$ & $\begin{array}{l}0.0965 \\
(0.04)\end{array}$ & $\begin{array}{l}0.0370 \\
(0.03)\end{array}$ & $\begin{array}{l}0.0512 \\
(0.02)\end{array}$ & $\begin{array}{c}-0.0253 \\
(0.07)\end{array}$ & $\begin{array}{l}0.0424 \\
(0.03)\end{array}$ \\
\hline $\begin{array}{l}0.3938 \\
(0.15)\end{array}$ & $\begin{array}{l}0.1665 \\
(0.07)\end{array}$ & $\begin{array}{c}-0.0055 \\
(0.02)\end{array}$ & $\begin{array}{l}0.1007 \\
(0.04)\end{array}$ & $\begin{array}{l}0.0657 \\
(0.04)\end{array}$ & $\begin{array}{l}0.0597 \\
(0.03)\end{array}$ & $\begin{array}{c}-0.0112 \\
(0.06)\end{array}$ & $\begin{array}{l}0.0393 \\
(0.03)\end{array}$ \\
\hline $\begin{array}{l}0.3640 \\
(0.13)\end{array}$ & $\begin{array}{l}0.1671 \\
(0.06)\end{array}$ & $\begin{array}{l}0.0178 \\
(0.01)\end{array}$ & $\begin{array}{l}0.0883 \\
(0.04)\end{array}$ & $\begin{array}{l}0.1492 \\
(0.09)\end{array}$ & $\begin{array}{l}0.0744 \\
(0.03)\end{array}$ & $\begin{array}{l}0.0001 \\
(0.04)\end{array}$ & $\begin{array}{l}0.0349 \\
(0.02)\end{array}$ \\
\hline $\begin{array}{l}0.3684 \\
(0.15)\end{array}$ & $\begin{array}{l}0.1641 \\
(0.06)\end{array}$ & $\begin{array}{c}-0.0029 \\
(0.04)\end{array}$ & $\begin{array}{l}0.0934 \\
(0.04)\end{array}$ & $\begin{array}{l}0.1789 \\
(0.14)\end{array}$ & $\begin{array}{l}0.0919 \\
(0.04)\end{array}$ & $\begin{array}{l}0.0040 \\
(0.03)\end{array}$ & $\begin{array}{l}0.0458 \\
(0.03)\end{array}$ \\
\hline $\begin{array}{l}0.4825 \\
(0.18)\end{array}$ & $\begin{array}{l}0.1334 \\
(0.05)\end{array}$ & $\begin{array}{c}-0.0307 \\
(0.03)\end{array}$ & $\begin{array}{l}0.0783 \\
(0.04)\end{array}$ & $\begin{array}{l}0.0566 \\
(0.05)\end{array}$ & $\begin{array}{l}0.1521 \\
(0.06)\end{array}$ & $\begin{array}{l}0.0019 \\
(0.04)\end{array}$ & $\begin{array}{l}0.0326 \\
(0.02)\end{array}$ \\
\hline $\begin{array}{l}0.4563 \\
(0.17)\end{array}$ & $\begin{array}{l}0.1433 \\
(0.05)\end{array}$ & $\begin{array}{l}0.0099 \\
(0.02)\end{array}$ & $\begin{array}{l}0.0785 \\
(0.04)\end{array}$ & $\begin{array}{l}0.0666 \\
(0.05)\end{array}$ & $\begin{array}{l}0.1445 \\
(0.06)\end{array}$ & $\begin{array}{l}0.0062 \\
(0.05)\end{array}$ & $\begin{array}{l}0.0330 \\
(0.02)\end{array}$ \\
\hline $\begin{array}{l}0.4510 \\
(0.16)\end{array}$ & $\begin{array}{l}0.1452 \\
(0.06)\end{array}$ & $\begin{array}{l}0.0019 \\
(0.01)\end{array}$ & $\begin{array}{l}0.0835 \\
(0.04)\end{array}$ & $\begin{array}{l}0.0635 \\
(0.05)\end{array}$ & $\begin{array}{l}0.1431 \\
(0.06)\end{array}$ & $\begin{array}{l}0.0024 \\
(0.05)\end{array}$ & $\begin{array}{l}0.0261 \\
(0.02)\end{array}$ \\
\hline $\begin{array}{l}0.4132 \\
(0.16)\end{array}$ & $\begin{array}{l}0.1594 \\
(0.07)\end{array}$ & $\begin{array}{c}-0.0011 \\
(0.03)\end{array}$ & $\begin{array}{l}0.0914 \\
(0.05)\end{array}$ & $\begin{array}{l}0.0518 \\
(0.07)\end{array}$ & $\begin{array}{l}0.0779 \\
(0.06)\end{array}$ & $\begin{array}{c}-0.0135 \\
(0.07)\end{array}$ & $\begin{array}{l}0.0330 \\
(0.03)\end{array}$ \\
\hline $\begin{array}{l}0.3957 \\
(0.15)\end{array}$ & $\begin{array}{l}0.1709 \\
(0.08)\end{array}$ & $\begin{array}{l}0.0003 \\
(0.03)\end{array}$ & $\begin{array}{l}0.0967 \\
(0.05)\end{array}$ & $\begin{array}{l}0.0148 \\
(0.02)\end{array}$ & $\begin{array}{l}0.0493 \\
(0.04)\end{array}$ & $\begin{array}{c}-0.0257 \\
(0.09)\end{array}$ & $\begin{array}{l}0.0316 \\
(0.03)\end{array}$ \\
\hline $\begin{array}{l}0.4255 \\
(0.17)\end{array}$ & $\begin{array}{l}0.1513 \\
(0.07)\end{array}$ & $\begin{array}{c}-0.0021 \\
(0.03)\end{array}$ & $\begin{array}{l}0.0877 \\
(0.05)\end{array}$ & $\begin{array}{l}0.0777 \\
(0.08)\end{array}$ & $\begin{array}{l}0.0980 \\
(0.06)\end{array}$ & $\begin{array}{c}-0.0049 \\
(0.06)\end{array}$ & $\begin{array}{l}0.0340 \\
(0.03)\end{array}$ \\
\hline
\end{tabular}


model 4 this process is a random walk; hence the own risk associated with future earnings depends on how distant they are in the future. Specifically,

$$
O R I S K_{t}=\sigma_{j} \sum_{\tau=0}^{\infty} \frac{K_{j, t+\tau} \tau^{1 / 2}}{\left(1+R_{f}\right)^{\tau}} / \sum_{\tau=0}^{\infty} \frac{E(\text { cash payout })_{\tau}}{\left(1+R_{f}\right)^{\tau}}
$$

The coefficients on RISK for the three sets of regressions show the same general variation over time, decreasing (becoming more negative) in the 1970s and reaching an absolute minimum in 1974. Firms that are riskier by the CAPM-based measure bear a larger discount in the latter part of the sample. The results for the cash-out case (table 10) appear to be the most satisfactory. Through 1967 the coefficients are of mixed sign and never significant; from 1968 on they are always negative and significant in six years. The coefficient in the pooled regression for the first subsample is not significantly different from zero; in the second subsample it has a value of -3.8 and a $t$-statistic of -6.17 . Perhaps surprisingly, the effect of RISK is not much smaller than that implied in regressions based on 5 , in which time and risk discounts are the only variables allowed to affect the valuation of a firm's earnings stream. The coefficients on $R I S K$ in the constant-capital case show the same general variation over time as in the cash-out case, but their level is less satisfactory. Although the coefficient on RISK is negative in the last six years of the sample and significantly so in three of these years, the coefficient is positive and often significant between 1962 and 1968. One explanation of this perverse result is as follows. These years form the peak of the market's gross rateof-return series as measured by Feldstein and Summers (see table 1). The rate-of-return forecast underlying the $Z$ calculations in the constantcapital case assumes that the market's gross rate of return follows a firstorder autoregressive process and asymptotically returns to 11.1 percent. If investors believed that the peak cash flows of the mid-sixties were less transitory than this process implies, they would have valued securities more highly than our intrinsic values, giving those firms with the largest covariance with the market rate the greatest overvaluation. Thus, if this scenario is correct, firms with large CAPM risk will also be systematically more valuable relative to our estimates of intrinsic value. Similarly, highrisk firms should be undervalued in periods of below-average aggregate return. To examine this hypothesis, we ran $Z$ regressions, not reported 
here, in which investors' expectations of the market return were assumed to follow a random walk. As would be expected if this explanation were correct, the resulting coefficients were negative in 1962-65 and less negative (and in some cases positive) in the 1970s.

These results make clear the difficulty of distinguishing between the effect of risk and expectations errors if a firm's rate of return is assumed to be related to the aggregate by the same coefficient that determines its risk. Any errors in forecasting the aggregate expected return automatically induce a correlation between $Z$ and the risk measure. This problem is probably less severe in the cash-out case because the distant future, when differences in the expected rate of return for the two processes are greatest, receives less weight. This explanation is supported by the results for model 7 reported in table 12 . In model 7 the intrinsic value calculations do not depend on the aggregate rate of return, and consequently there is no reason to believe that errors in our forecast of expected return are correlated with the risk measure. The coefficients for risk in this case are never significantly positive and become significantly negative in 1973, 1976, and 1977.

Although diversifiable risk is not supposed to matter according to the capital-asset pricing model, various authors find that it has a negative effect. In the cash-out case, ORISK typically has a negative sign and is highly significant in the earlier half of the sample. This pattern of significance is just the reverse of that for RISK - the market appears to assign relatively less weight to diversifiable risk and relatively more to systematic risk in the second half of the sample. According to our estimates for that part of the sample, eliminating own risk would have roughly the same effect on market value as eliminating nondiversifiable risk.

In the constant-capital case the coefficients on ORISK, like those on RISK, are unsatisfactory. A natural explanation is that model 4 , which makes the extreme assumption that the firm-specific error follows a random walk, induces a correlation between ORISK (which varies inversely with intrinsic value) and $Z$. Again, the importance of this error should be greater in the constant-capital than in the cash-out case. The results for model 7 should not be as vulnerable to this problem. As can be seen in table 12, the coefficients on ORISK for this case tend to be negative and are significantly so in four years. However, in contrast to RISK, they do seem less important in the second half of the sample. 


\section{EFFECTS OF ANTICIPATED INFLATION}

It is often argued that, under current U.S. tax laws, inflation increases the real tax burden on corporate capital and thus affects valuation of corporate securities. Our procedure is designed to capture the effects of anticipated inflation on after-tax cash flows under the assumption that before-tax cash flows are invariant to changes in anticipated inflation. Inflation alters the real tax liabilities of the firm in three ways: by producing nominal inventory profits for firms on FIFO, by permitting firms to charge as an expense nominal interest charges, and by using historical cost for calculation of depreciation allowances.

Changes in anticipated inflation may affect future after-tax cash flows and hence asset values in ways not immediately apparent from measures of current flows. A one-time increase in expected inflation will gradually reduce the real value of depreciation charges, bringing them to a new steady state after the time required to depreciate the existing capital stock completely. Thus, if the real capitalization rate remained unchanged, the ratio of market value to after-tax profits in the current period would fall immediately after a change in anticipated inflation.

To illustrate this effect, consider a firm that maintains a constant stock of capital with a twenty-year useful lifetime, purchasing one unit of capital each year. If straight-line depreciation is used, the real value of nominal depreciation charges in each year is

$$
\frac{1}{20} \int_{0}^{20} e^{-\pi_{0} t} d t=\frac{\left(1-e^{-20 \pi_{0}}\right)}{20 \pi_{0}}
$$

when the historical inflation is the constant $\pi_{0}$. The present value of the tax savings is the annuity value of this stream multiplied by the marginal tax rate on corporate income. A rise in the anticipated inflation from 5.0 to 10.0 percent will reduce the steady-state flow, and thus the value of tax savings by 31.5 percent. There will be, however, no instantaneous effect on the real flow. The real value of the nominal depreciation charge is

$$
\int_{0}^{\tau} \frac{e^{-\pi_{1} t} d t}{20}+\int_{\tau}^{20} \frac{e^{-\pi_{1} \tau-\pi_{0}(t-\tau)}}{20} d t
$$

when the inflation rate changed from $\pi_{0}$ to $\pi_{1} \tau$ years ago. After a single year, for example, a rise in anticipated inflation from 5.0 to 10.0 percent 
will reduce the real value of the flow by 4.8 percent, and after five years the flow will be reduced by 18.2 percent. If the real discount rate is unaltered by changes in expected inflation, the effect on the discounted stream of depreciation charges will be an average of the relatively low initial effect and the greater future amounts. At a 3.0 percent real discount rate the present value of future real depreciation charges in our example will fall by 20.8 percent at the moment the inflation rate changes, which is about two-thirds of the steady-state effect.

The magnitude of this effect on market valuation is related to the importance of nominal depreciation charges. In 1973, book depreciation for our sample averaged about 45 percent of net cash flows. Thus, for the hypothetical real discount rate of 3 percent, a rise in anticipated inflation from 5.0 to 10.0 percent would reduce the value of a typical firm by the marginal tax rate multiplied by 20.8 percent multiplied by book depreciation divided by net cash flow, or about 4.4 percent at a marginal tax rate of 0.48 . Because this calculation probably understates the real discount rate and because it is hard to imagine a 5 percent change in the expected long-run inflation rate in one year, the calculation suggests only a minor role for this effect in the market decline between 1973 and 1974.

The explanatory variable, $B L O A T 2$, measures the difference between our estimates of real and book depreciation divided by gross after-tax cash flow and, in a given year, varies across firms proportionately with the average age of existing capital. A significant coefficient for this variable in the $Z$ regressions can be given various interpretations. An ultrarational view would attribute this coefficient to market anticipations of inflation different from those we have assumed. A negative coefficient, for example, could imply that the market anticipates higher inflation than we assume and thus lower after-tax returns. A more prosaic interpretation would attribute this coefficient to investors either being fooled by reported income statements or disagreeing with our adjustment for inflation. A positive coefficient, for example, would imply that investors believe reported book figures or that we have overstated the difference between replacement cost and book depreciation.

The results from our cross-sectional regressions are ambiguous about the consistency of our depreciation adjustments and the market's view. For model 4, in both the cash-out and constant-capital cases the coefficients tend to be positive and insignificant in the annual regressions, 
but significant in several of the pooled regressions. The coefficients for model 7 , on the other hand, are typically negative but insignificant through 1974 . The coefficient is significantly negative in the last years of our sample.

As mentioned above, not all tax effects of inflation are harmful to holders of corporate capital. Because nominal interest charges are deductible as an expense, inflation reduces the real tax liability of the firm to the extent that nominal interest rates rise with anticipation of inflation. A precise calculation of this effect requires an assumption about the future debt policy of the firm, which in the absence of a well-accepted optimal policy is somewhat arbitrary.

In our calculations we assume that firms finance a constant fraction of new capital expenditures with debt. If all debt has the same maturity, the real value of debt outstanding will decline with anticipated inflation; interest payments represent in part repayment of principal. This decline in the real value of debt will diminish the advantage inflation provides through this channel compared with a policy that holds constant the real value of debt. For sufficiently high inflation rates, increases in inflation will actually reduce tax savings from debt.

To illustrate this effect, consider a firm that, as before, maintains a constant-capital stock adding one unit of capital each year and financing a fraction, $b$, of new capital with twenty-year bonds. For a constant inflation rate, $\pi_{0}$, the real value of debt is equal to

$$
b \int_{0}^{20} e^{-\pi_{0} t} d t=\frac{b\left(1-e^{-20 \pi_{0}}\right)}{\pi_{0}},
$$

which declines with expected inflation. At a real interest rate of $\rho$, the real value of interest payments is

$$
b \frac{\left(\pi_{0}+\rho\right)}{\pi_{0}}\left(1-e^{-20 \pi_{0}}\right),
$$

which, for a low positive interest rate, rises and then falls with inflation. A rise in inflation of 5.0 to 10.0 percent will raise the steady-state cash flow by 11.1 percent with $\rho$ equal to 3.0 percent. By comparison, if a firm had a policy of maintaining constant real value of outstanding debt, the change in the real stream would be proportional to the change in nominal interest rates, or 62.5 percent.

As in the case of depreciation, the effects of changes in inflation will 
be drawn out over time. The value of real interest charges $\tau$ years after a change in inflation from $\pi_{0}$ to $\pi_{1}$ is given by

$$
b\left[\left(\pi_{1}+\rho\right) \int_{0}^{\tau} e^{-\pi_{1} t} d t+\left(\pi_{0}+\rho\right) \int_{\tau}^{20} e^{-\pi_{1} \tau-\pi_{0}(t-\tau)} d t\right] .
$$

The present value of this stream will increase by about 7.8 percent at the instant that inflation increases from 5.0 to 10.0 percent, compared with the steady-state rise of 11.0 percent. Because about 30 percent of net cash flows is distributed as interest, a rise in expected inflation can be expected to increase the aggregate value of corporate securities by 0.30 multiplied by 7.80 percent multiplied by 0.48 , or about 1.1 percent. A policy of maintaining the real value of debt through time would induce a much larger effect: 0.300 multiplied by 0.625 multiplied by 0.480 , or 9 percent.

The consistency between our adjustments to future after-tax earnings and the market's assessment is tested in the regression by our inclusion of the variable PINT, which is defined as the ratio of interest to gross aftertax cash flows. This variable also provides a test of the first part of the Modigliani and Cohn hypothesis: that equity holders fail to take into account the gain resulting from the depreciation in the real value of nominal liabilities in inflationary environments. They believe this factor has been increasingly important in recent years as inflation has accelerated and that it has contributed to the observed market decline. A test of this theory is to examine whether those firms with high debt-equity ratios are undervalued relative to equity-financed firms with similar earnings characteristics. If firms have similar age and maturity structures of their financial liabilities, PINT is a proxy for the debt-equity ratio of the firm. With this interpretation, the Modigliani-Cohn hypothesis would imply that the coefficient on PINT would be negative and increasing in absolute value during the 1970s. In fact, all our results show that the coefficient on PINT is small, trendless, and insignificant in all years except one. Contrary to the Modigliani-Cohn hypothesis, firms with interest-intensive cash flows and high debt-equity ratios do not appear to be especially undervalued in the market in the 1970s. However, this test is biased against acceptance of that hypothesis to the extent that firms are expected to maintain their ratios of real debt to capital.

There is a part of the Modigliani-Cohn hypothesis that fares better: investors discount corporate cash flows at the nominal rather than at the real rate of interest. Our results are at least consistent with this second 
part because it could be argued that the risk-free internal rates of return that we display in table 9 more closely resemble nominal bond rates than anyone's estimates of real rates.

The effects of inflation on taxation of inventory profits is qualitatively similar to the treatment of depreciation charges. However, because inventory is turned over much faster, the transition effects will be negligible and the instantaneous effect on asset values will be close to the steadystate effects. From table 13 the estimated inventory valuation adjustment $B L O A T 1$ for our sample appears to be approximately 6.4 percent (in 1977) of gross and 11.6 percent of net after-tax cash flow. Because this is proportional to realized inflation, 6.8 percent in 1977 , a change from 5.0 to 10.0 percent in anticipated inflation could be expected to double average inventory valuation adjustment from 8.5 to 17 percent of net cash flows. This would reduce steady-state after-tax cash flows and hence the value of corporate capital by about 4 percent. The puzzle, of course, is why firms choose to pay this voluntary tax when they could avoid it by changing their accounting method. The variable $B L O A T 1$ in our regressions measures the ratio of inventory valuation adjustment to gross cash flows. As in the case of $B L O A T 2$, a significant value of this coefficient can be interpreted as an indication that investors' expectations about inflation differ from our assumptions, that there is accounting illusion, or that there are errors in our calculations of the inventory adjustment itself. The estimated coefficient is typically negative after 1968, although not significantly so except in the pooled regressions. This suggests that, if anything, our adjustments for inventory profits are smaller than the market's in the second half of our sample period.

\section{VALUATION OF DISTANT FUTURE EARNINGS \\ AND THE IMPORTANCE OF RENTS}

Several variables included in the regressions provide information about the relative importance, and changes in importance, of future earnings to the current valuation of the firm. The most straightforward variable to interpret is $F I V E$, which is simply the ratio of the present value of the first five years of gross cash flows to the present value of the entire future stream of returns:

$$
F I V E=\sum_{\tau=1}^{5} \frac{G C F_{\tau}}{\left(1+R_{f}\right)^{\tau}} / \sum_{\tau=1}^{\infty} \frac{G C F_{\tau}}{\left(1+R_{f}\right)^{\tau}}
$$


The coefficient on this variable indicates whether distant future earnings are valued more or less highly than they are in our calculation of intrinsic value. A positive coefficient would indicate an upward-sloping term structure (we have assumed a level structure) or pessimism relative to our projections about distant future earnings.

This variable should have the best chance in the constant-capital cases reported in tables 11 and 12 . There appears to be no obvious relation between this coefficient and the term structure of nominal interest rates. Furthemore, although the variable is significantly positive in 197577 , it is hard to argue that it is capturing an "end of the world" psychology during the period of the market's sharpest decline. For model 4 the variable is not significant in 1973 and is negative (although insignificant) in 1974. For model 7 the coefficient is significantly negative in 1974. For both models, however, the coefficient does become significantly positive in 1975-77.

The most important variable for reconciling market value with our estimate of intrinsic value is the gross rate of return itself. The coefficient estimates are typically positive, indicating that this variable may well reflect the presence of intangible assets such as trademarks, patents, monopoly power, or key personnel, which contribute to measured profitability. The fact that the coefficient on this variable is much greater in the cash-out than in the constant-capital case suggests that those assets do not depreciate as quickly as the tangible assets we measured. For both models considered, the coefficient on $G R A T E$ is positive and usually significant until 1974. From 1974 on, however, the coefficient is much smaller; in the constant-capital cases, it is never significant. This pattern is consistent with the view that the market believes the quasi-rents that had been important in earlier periods are not very likely to continue. The negative, and frequently significant, coefficient on the change in GRATE suggests that the market regards recent changes as more transitory than our projections do. As would be expected under this interpretation, the coefficients are typically smaller in absolute value for model 7, which uses lagged GRATE in forecasting future earnings, than for model 4, which assumes a random walk for the firm-specific error.

The variable GROWTH is included in the constant-capital regressions to examine whether estimated net rates of return contribute more to the market value of firms with high growth rates than those with low rates. The GROWTH variable is defined as the percentage change in the firm's net capital stock between year $t$ and year $t-3$ multiplied by the firm's net 
rate of return in year $t$. The coefficients on GROWTH are insignificant for most of the sample, but become larger and significant in the last four years for model 4. In model 7, on the other hand, in which GROWTH presumably adds less information about future expected returns, it is never significant.

\section{OTHER VARIABLES AFFECTING MARKET VALUES}

The other explanatory variables included in our regressions are intended to control for factors that are omitted in our estimates of intrinsic value. These factors may be important because they provide information about expectations of future cash flows, because they affect the valuation of these earnings, or because they offset errors we have introduced in our calculations. The coefficient on the DIV variable (the ratio of dividends to gross after-tax cash flows) tends to be positive and is significant for the pooled sample for model 4 . The magnitude of $D I V$ is particularly large and significant in the last four years of our sample. In model 7, however, the coefficient on dividends has mixed signs and is not significant in the pooled regressions. Because dividends were used in model 7 to forecast expected earnings, this comparison of results suggests that dividends are serving as a proxy for expected return rather than as a preferred means of receipt in model 4 . Even in model 7, however, the value of dividends increased markedly during the last three years of the sample. It may not be too fanciful to suggest that this reflects the market's preference for receiving cash over investment in physical capital, which is perceived, on average, to be an unattractive use of funds.

The BLOAT3 variable is the difference between our estimated value of book depreciation and what the firms actually report (again, scaled by gross after-tax cash flows). The variable takes on a positive value if our depreciation lives are too short, which would also cause our intrinsic value measures to be underestimates of the cash-flow value of the firm. The regressions reliably obtain positive and significant coefficients for this variable (especially for the constant-capital case), suggesting that the variable is capturing our errors in estimating useful lives.

$R I N V$ is the ratio of gross investment to net capital stock. One can rationalize either a positive relation between this variable and profitability (as firms expand to take advantage of favorable opportunities), or a negative relation reflecting the fact that as firms expand they move down 
their schedules of marginal efficiency of capital. The regressions in table 3 forecasting rates of return indicate that initially the former effect dominates, but that after a few years it disappears. The $Z$ regression results of tables 10 and 11 indicate that investment is quite consistently rewarded with higher market valuations.

\section{Conclusions}

Observers have offered several explanations for the dramatic decline in the financial valuation of the U.S. corporate capital stock relative to its total return, earnings plus interest. These include (1) a riskier economic environment (that is, greater uncertainty about the return on capital), or increased aversion to risk, (2) an increased tax burden on corporate earnings as a result of inflation, (3) valuation confusion caused by inflation, and (4) a decrease in expected rates of return-for example, from higher energy prices or the added burden of government regulation. The calculations made for our sample of 187 firms using a variety of models for forecasting future earnings confirm a large decline in market value relative to the present value of the after-tax cash flows, with either a constant real rate or an inflation adjusted bond rate. Put another way, the real discount rate required to equate market and present values has shown a dramatic increase from an average of less than 5 percent in the last half of the 1960s to an average of more than 10 percent in 1974-79.

These results do not arise because our projections of future earnings are particularly optimistic. The sharp decline in $Z$ appears even with our most pessimistic projections, which assume a continuation of the low, by historical standards, before-tax rates of return experienced in the latter part of the sample period. Although these rates presumably already incorporate the effects of past energy price increases, the market may expect even further deterioration. It is unfortunate that our cross-sectional data provide no more information about the possibility of future energy hikes and their likely effects than do aggregate data.

Cross-sectional data do contain information that can be used to assess the importance of increased risk discounts or the Modigliani-Cohn "inflation confusion" in explaining the decline in market value. Firms differ in their vulnerability to fluctuations in the aggregate rate of return. Hence if investors perceive increased risk to the aggregate, it should show 
up differentially among firms. Similarly, if bondholders recognize the effect of inflation on the real value of their claims, but equity holders fail to recognize that the inflation component of nominal interest payments are effectively repayment of principle, debt-intensive firms should be systematically undervalued.

We find that if nondiversifiable risk is the only variable, besides a time discount, allowed to explain cross-firm variation it appears to be quite important in explaining the market's decline in 1974. However, it does little to explain the level of the market thereafter. Our year-by-year crosssectional regressions for $Z$ provide a more powerful test of the importance of risk, forcing it to compete with variables that could capture inflation illusion or other influences on market value. The estimated coefficients on the two risk measures used in these regressions indicate that they are important in explaining market value, but that changes in their importance do not explain much of the puzzle. For example, in our preferred model (constant capital, model 7) our estimates imply that together the increases in risk discounts explain only 4 percent of the decline in market value between 1965 and 1974. A comparison of the coefficients of the different earnings models also makes clear the difficulty of distinguishing between the effect of nondiversifiable risk and errors in forecasting future rates of return.

The variable PINT, which is intended to reveal the presence of inflation confusion by equity holders, is even less successful than risk in explaining the market decline. The coefficient on PINT is small, trendless, and insignificant in all except one year.

General pessimism about the future is perhaps the hardest to infer from cross-sectional analysis. However, changes over time in the coefficients on several variables do suggest such a loss of confidence. Firms that we estimate to have a relatively high fraction of present value from returns more than five years in the future are relatively undervalued late in the sample, as are firms that have had historically high net rates of return. Perhaps even our most pessimistic earnings projections have not reflected the fears of the market. What does seem clear is that measurable characteristics of firms and conventional methods of projecting future earnings are not likely to explain the declines in market values that have occurred during the 1970s. 


\section{Comments and Discussion}

Phillip Cagan: The stock market has lately become a subject of intensified research to discover why real stock prices are so low in an inflationary environment. In the traditional view, stocks protect against inflation and should be bid up relative to earnings when inflation escalates. As Brainard, Shoven, and Weiss show, the market value of companies relative to replacement cost of capital (the $q$ ratio) fell by more than half from 1968 to 1977 . There is no reason to deny the personal interest of many of us in the research on this development. Many of us have been acquiring common stocks for our CREF retirement pensions over the past dozen years at low prices and are wondering whether (indeed, anxiously hoping that) $q$ will return to its long-run equilibrium value of around unity, thus raising the value of our pensions dramatically by the time we retire.

The future behavior of stocks will depend on the reason for the initial decline in $q$. A priori there are many possible reasons for such a decline. Real corporate earnings per unit of capital could have declined because of increased energy costs and higher tax rates related to inflation, or reported earnings could be overstated because of inflation. Other studies have reported a decline in rates of return on corporate capital after taxes and after adjustments for rising replacement costs, but the decline does not appear large enough to explain the fall in market value, and the authors also estimate that the after-tax net rate of return declined by a quarter from 8 percent a year in 1968 to 6 percent in 1977 (table 1, overlooking 1973-74), which would account for only half of the corresponding decline in $q$. Some of this decline in rate of return can be attributed to higher taxes pushed up by inflation, which proposals to reduce corporate tax rates seek to reverse. The remainder of the decline in rate of return 
is unexplained, but any part due to OPEC will not be reversed by reduced energy costs in the near future.

Later in the paper, however, the authors derive internal rates of return, which generally show a doubling over the 1968-77 period. This implies that average returns to capital explain none of the decline in $q$.

A large part or all of the decline in $q$ therefore reflects a decline in the market value of corporate capital and earnings, which is usually attributed to a change in risk or in its price. The authors provide a variety of ingenious measures of risk, which they estimate from a cross section of 187 firms each year from 1958 to 1977 . I have doubts that 187 firms are enough to give a good representation of the market, given the accounting and capital differences one finds between various manufacturing industries, utilities, retail trade, services, airlines, railroads, and companies owning minerals or timberlands. It would be desirable to increase the sample and reduce the disparity. (I have found 485 manufacturing firms on the compustat tape, which had data available since 1965 or before and did not have major mergers or average acquisitions over 10 percent a year of capital.)

But even with a limited sample, the authors' results are intriguing and quite plausible. They first calculate internal rates of return without adjustment for risk; these rates equate the discounted stream of future earnings (projected by various methods) to the present market value of the firm (equity and all debt). The internal rate doubled from 4.6 percent a year in 1968 to 9.3 percent in 1977 (see table 7 for "constant capital," which represents the normal view of firms as continuing indefinitely rather than being terminated when present capital wears out). This rise matches a halving of $q$, and implies that projected future earnings per dollar of capital have not declined.

The authors then calculate an internal rate adjusted for risk. The risk adjustment for each year is estimated from differences among a cross section of firms in the nondiversifiable risk of their future returns. If firms with a high risk relative to the average have relatively high internal rates of return for a particular year, the cross-sectional regression equation will assign an important role to the risk adjustment. If the size of this risk adjustment were to rise over the years, it could help explain the rise in the unadjusted internal rates.

The risk adjustment does rise in 1973-74 (table 9), yet explains only part of the concurrent sharp rise in the unadjusted rate, and furthermore 
the adjustment declines thereafter. Consequently, the rise in the unadjusted rate between 1968 and 1977 is not reduced at all by this estimate of risk.

In subsequent tables in which regression equations are calculated for the internal rate of return each year on company betas, own risk, and a string of other variables, the estimated coefficients for the beta and ownrisk terms do not help to explain most of the rise in the unadjusted rates of return.

In this part of the study, therefore, a negative answer would be given by tests of whether risk as indicated by cross-sectional differences among firms has increased over the years and whether risk would explain the decline in real stock prices over the period. The negative finding shows that the decline in stocks was not led by firms that the market treated as having relatively high risk. I am not surprised by this result, because there was never any indication that the prices of stocks displayed such differential behavior in those years. But it is reassuring to have this thorough analysis, subject to the qualification that the sample may not be representative.

By elimination, one is left with the implication that market values have declined relative to returns and capital and that for some reason the market rate of discount rose, either because of a mistaken use of the higher nominal-rather than the largely unchanged real-rates of interest on bonds or because of an increase in the price of a given degree of risk or in the perceived riskiness of returns from corporate capital in general. Although this study combines the equity and nonequity return to capital, it is probably true that most of the decline in market valuation applies to the equity portion. I do not know of a satisfactory way to test whether the perceived risk of all corporate capital has increased relative to other forms of investment. We shall have to wait another ten years or so to see what happens, and even then we may never be sure.

I do not find the hypothesis of a change in perceived riskiness implausible, however, in view of the fact that most of the drop in $q$ and rise in internal rates occurred broadly and sharply in 1973 and 1974 (see table 2 ), rather than gradually over a period of years as one might expect for a rise in the actual variance of projected future returns or for a tendency to discount with nominal interest rates. Moreover, the years 1973 and 1974 were not ordinary years but brought events that shook up investors' perceptions of the environment-its vulnerability to shocks and escalat- 
ing inflation. If this hypothesis is correct, the change in perceptions should be reversed in due course, which is good news for CREF participants, at least for those who do not retire too soon.

This study also touches briefly on the effect of inflation adjustments of reported corporate earnings on market values. In the regression equations of table 11 the coefficients on the ratio of inventory valuation adjustment to cash flow and of replacement cost to book depreciation are generally not significant. These variables test whether market values appear to depend on reported earnings based on historical cost accounting or on earnings adjusted for replacement costs of capital and inventories. The insignificance of the variables suggests that market valuations are based on adjusted returns.

In a current study of mine the results are quite different. Market values appear to be influenced by inventory valuation adjustment and replacement cost depreciation, but only partially; there is closer correspondence to book costs than to replacement costs. I cannot account for the difference in our results because our regression equations are set up quite differently. But, in any event, a finding that market values are based on reported earnings does not help to explain the drop in $q$ and rise in internal rates because the adjustment for replacement costs reduces reported earnings during inflation.

Robert E. Hall: This paper embodies a staggering investment in data gathering and manipulation to give modern theories of market valuation a chance to explain the low real value of common stocks. The verdict is a strong confirmation of the hypothesis of gross undervaluation of corporate earnings. All respectable economic explanations of the weak stock market are found wanting. In particular, inflation-induced increases in effective tax rates cannot fully explain low market values. Only the surge in stock prices since the authors began work on the paper threatens to undermine its conclusion. As they point out, the current puzzle of undervaluation is just part of a more general phenomenon of volatility of stock prices in excess of what is explained by the fundamentals.

The authors work within one of the important conclusions of finance theory, the irrelevance of dividends. The market values the profitmaking potential of the firm, whether or not the stockholders receive the profit as dividends currently. Whatever the firm retains, it can invest and pay out the returns later. Even if a firm made an iron-clad promise never to 
pay dividends, it would still be fully valued by the market because the firm itself could be sold. But the paper finds finance theory inadequate as an explanation of the depressed stock market, so it may pay to look at dividends as an added source of information.

The first thing to notice about dividends is their higher discounting in the market of the late 1970s compared to earlier years. The average dividend yield of the Standard \& Poor's 500 rose from 3.2 percent in 196073 to 4.6 percent in 1974-79. Second, the fraction of corporate income paid out as dividends has declined sharply. The payout ratio from book earnings in the Standard \& Poor's 500 fell from 55 percent to 45 percent from 1960-73 to 1974-78. According to Brainard, Shoven, and Weiss, dividends were 19 percent of gross cash flow in their sample in 1960-75 and only 13 percent in 1974-77. Not only are corporations more cautious in paying dividends, but the market is suspicious about the value (that is, the potential growth) of the dividends that are paid.

For the Standard \& Poor's 500, dividend payouts have fallen to 78 percent of their earlier levels, and the market valuation of dividends has fallen to 69 percent. The product, 53 percent, is representative of the current value of the authors' $Z$ index of actual to fundamental market values. Similarly, in their sample, dividend payouts from gross cash flow have fallen to 67 percent of their earlier values; if, as in the Standard \& Poor's 500, the market value of dividends is 69 percent of its earlier value, the market value of the sample is 46 percent of its earlier level, again close to the reported change in $Z$. This adds to my already high confidence in the findings of the paper.

If management had whimsically cut dividends, market value would not have changed, finance theory tells us, or value might have risen, because of the adverse tax treatment of dividends. Indeed, finance theory tells us that dividends ought to be zero on stocks held by owners with higher tax rates on dividends than on capital gains.

Instead of welcoming the cut in dividend payouts, the stock market has reacted as if management did not go far enough, so dividends must be valued at lower multiples than before. There seems to be something that management and the market agree has dramatically worsened the financial picture of the firm, even though it does not show up in gross cash flow, book earnings, or the authors' intrinsic value. Nor, for that matter, does it show up in higher taxes or in any properly inflationcorrected earnings. 
Franco Modigliani and Richard Cohn blame the declining values of firms on two forms of inflation illusion. The rise in dividend-price ratios fit their idea roughly - at about the same time, minimal interest rates rose. Modigliani and Cohn attribute this to market unawareness of dividend growth at roughly the rate of inflation, so the market should equate dividend yields and real interest rates. The other element of Modigliani and Cohn's case is lack of market recognition that much so-called interest paid by firms is actually repayment of debt. But book earnings are conservative on this point: if management is as ignorant as the market, it should keep dividends at a constant fraction of book earnings; if management is shrewd, it should raise dividends relative to book earnings. Nothing on this account explains the decline in payouts relative to book earnings.

I am convinced by the authors that rising risk or rising discounting of risk explain only a fraction of the decline in market values.

What is left as an explanation? One possibility is that real returns to substitutes for stocks-real estate, direct investment, and financial assets other than stocks-have risen sharply. Certainly, real returns to bonds have not risen, and this is a serious obstacle to this line of argument.

Whatever the explanation of low market values, the lesson seems to be to buy stocks. I trust that the authors will send the interested reader a list of the ten stocks with the lowest $Z$ for personal investment purposes.

\section{General Discussion}

Lawrence Summers suggested that the puzzle the authors set out to explain is a nonphenomenon. According to Summers' calculations, if personal income as well as corporate taxes are taken into account, the ratio of after-tax earnings on capital to the market value of debt plus equity has actually been fairly constant since 1955 . Thus corporate capital as a whole is not undervalued. The real puzzle is the relative undervaluation of equity compared to debt. The decline in the ratio of the market value of capital to before-tax profits can be explained partly by the increase in the marginal tax rate caused by inflation and partly by the decline in the earnings documented by the authors. Brainard observed that, according to their calculations, it requires approximately a doubling of the real discount rate on earnings before personal taxes to explain the market 
value of bonds plus equity. He wondered whether the implied increases in the marginal personal tax rates are plausible, particularly given the increased importance of pensions and other tax shelters. An explanation that rests on a higher required before-tax return also seems inconsistent with the apparent decline in the required real rate on bonds in spite of their increased riskiness.

Summers noted that the estimates of the degree of undervaluation were lower the more weight was given to future earnings in calculating present values. He observed that there was less of a puzzle to be explained in the calculations that assumed the maintenance of capital than in those in which firms were cashed out; and he suggested that if the authors had gone still further and assumed that companies planned to expand their capital rather than merely maintain it, they would have further reduced the puzzle to be explained.

Martin Baily observed that the decline in the market valuation of corporations is so great that there is room for more than one explanation. He suggested that the value may appear low because the physical quantity of capital that is being valued in the market has been overstated. One piece of evidence in support of this view is the fact that measured $q$ has remained below unity for a substantial period. Baily found it implausible that an accurately measured $q$ would differ from its equilibrium value for so long. Overestimation of the capital stock, either because of underestimation of depreciation on downward biases in the price indexes of capital goods, would simultaneously help explain the stock market, the slowdown in productivity and growth, and the persistence of relatively strong investment. While agreeing with the possibility that the capital stock is overestimated, John Shoven found it difficult to believe that any such overestimation could be large enough to account for the rapid changes in the market valuation of firms of the magnitude observed in the late 1960s and after 1972.

Franco Modigliani said that the general conclusion he drew from this study is that the discount rate required to explain the market has moved roughly with nominal interest rates. His own investigations, which looked at changes in the prices of firms during inflationary periods, led to this same conclusion. Robert Hall questioned the timing involved in Modigliani's explanation, noting that it did not work very well before 1972 . Modigliani acknowledged this but said that over the entire 1965-78 period the relation had been remarkably good. Summers asked why home- 
owners were not suffering from similar types of inflation illusion. Modigliani replied that they were actually able to realize the capital gains on the underlying asset, houses, whereas stockholders were only able to sell their claims on the underlying corporate capital stock, and these claims have declined in value with increases in nominal rates from the first increase in inflation.

There was considerable discussion of the nature and importance of the risks that may be relevant to market valuation. Summers pointed out that the authors had looked at the relation between returns on individual firms and aggregate corporate earnings plus interest whereas theory suggests that the relevant relation is that between the returns on individual firms and the returns on all holdings in their portfolios, including human capital. He noted that corporate capital is only a relatively small share of total wealth broadly defined, and it is therefore possible that quite different estimates of the price of risk might result from using his broad concept of wealth in measuring it. Modigliani reported that there is apparently no significant relation between changes in the prices of stocks and the more conventional beta measures of the risk on total return during the two inflationary periods, $1968-73$ and 1973-78.

William Fellner suggested that investors perceive a different kind of risk today from that which is observable in past time-series. According to Fellner, investors believe that the inflationary economy today is untenable in the long run, and they are afraid that either an exceedingly uncomfortable period of adjustment lies ahead or an extremely inefficient economy with very low productivity growth.

Alan Greenspan agreed with Fellner that the nature of risks may have changed. He suggested that there is a perception of increased risk to the property rights that underlie corporate capital. Because there has been no apparent relevant change in property rights relating to land or noncorporate capital, this increased risk helps explain the changes in the relative valuation of these assets. Brainard agreed that the historical covariation of firms' earnings with the aggregate probably does not provide much information about the relative vulnerability of those firms to such changed perceptions of corporate capital as a whole. He suggested that unless these hypotheses could be sharpened to give distinctive implications-for example, about the differential valuation of firms with different characteristics or the valuation of corporation capital in different countries-it would be difficult to distinguish their importance from that of the many 
other hypotheses about the market's decline. He also said Greenspan's hypothesis would be more persuasive if it were more specific about what losses of property rights are involved. The current discussions of revisions in the corporate tax law, the bailout of Chrysler, and the political climate generally do not suggest that corporate capital has suddenly become an endangered species.

Discussion turned to the problem of understanding the strength of investment despite extremely low $q$. Fellner suggested that the signal to the firm from a low value of $q$ was partly offset by the firm's ability to borrow at low real rates by issuing debt. Modigliani pointed out that even firms that were completely equity financed were investing despite the fact that the market value of such investments was lower than their costs. $\mathrm{He}$ noted, in a comment on his view of why equities are undervalued, that firms would continue to invest if they make the same error as the market.

Other comments were directed to specific results. Benjamin Friedman said that other studies had found that high yield stocks tend to be underpriced whereas this paper implied that the market rewarded large dividend payments. Laurence Weiss observed that, in the present sample of firms, dividends appear to be positively correlated with future earnings and that the estimated effect of dividends on market price is reduced if expected earnings are held constant. He agreed that, given tax law, it is hard to understand why higher dividends should increase a firm's value for a given level of expected earnings. Albert Wojnilower noted that firms that pay high dividends tend to hold more financial assets and therefore to have lower values during periods of hyperinflation. Summers found it puzzling that the authors had not found that inventory profits affect valuation because firms with FIFO pricing practices enjoy the prospects of higher after-tax earnings when they switch to LIFO. Summers also found the tests of the Modigliani-Cohn hypothesis flawed because they had looked at the value of equity plus debt whereas he believed the "PINT" variable should be used to explain the value of equity alone. Weiss responded that the issue was the extent to which the expectations of bonds and stockholders are consistent - whether the loss from inflation by bondholders was perceived as an equal gain by stockholders. This question is directly answered by relating the value of debt plus equity values to PINT. 